Prepared for the U.S. Department of Energy

under Contract DE-AC05-76RL01830

\title{
Hanford Sludge Simulant Selection for Soil Mechanics Property Measurement
}
BE Wells
GN Brown
EC Golovich
RL Russell
DE Rinehart
JV Crum
LA Mahoney
WC Buchmiller

March 2010

\section{Pacific Northwest}

NATIONAL LABORATORY

Proudly Operated by Battelle Since 1965 


\title{
DISCLAIMER
}

This report was prepared as an account of work sponsored by an agency of the United States Government. Neither the United States Government nor any agency thereof, nor Battelle Memorial Institute, nor any of their employees, makes any warranty, express or implied, or assumes any legal liability or responsibility for the accuracy, completeness, or usefulness of any information, apparatus, product, or process disclosed, or represents that its use would not infringe privately owned rights. Reference herein to any specific commercial product, process, or service by trade name, trademark, manufacturer, or otherwise does not necessarily constitute or imply its endorsement, recommendation, or favoring by the United States Government or any agency thereof, or Battelle Memorial Institute. The views and opinions of authors expressed herein do not necessarily state or reflect those of the United States Government or any agency thereof.

\author{
PACIFIC NORTHWEST NATIONAL LABORATORY \\ operated by \\ BATTELLE \\ for the \\ UNITED STATES DEPARTMENT OF ENERGY \\ under Contract DE-ACO5-76RL01830
}

Printed in the United States of America
Available to DOE and DOE contractors from the
Office of Scientific and Technical Information,
P.O. Box 62, Oak Ridge, TN 37831-0062;
ph: (865) 576-8401
fax: (865) 5765728
email: reports@adonis.osti.gov

\author{
Available to the public from the National Technical Information Service, \\ U.S. Department of Commerce, 5285 Port Royal Rd., Springfield, VA 22161 \\ ph: (800) 553-6847 \\ fax: (703) 605-6900 \\ email: orders@nits.fedworld.gov \\ online ordering: http://www.ntis.gov/ordering.htm
}




\section{Hanford Sludge Simulant Selection for Soil Mechanics Property Measurement}

$\begin{array}{lll}\text { BE Wells } & \text { GN Brown } & \text { EC Golovich } \\ \text { RL Russell } & \text { DE Rinehart } & \text { JV Crum } \\ \text { LA Mahoney } & \text { WC Buchmiller } & \end{array}$

March 2010

Prepared for

the U.S. Department of Energy

under Contract DE-AC05-76RL01830

Pacific Northwest National Laboratory

Richland, Washington 



\section{Summary}

This report describes current work to select or develop two chemical sludge simulants for testing relative to problems of hydrogen gas retention and release encountered in the double shell tanks at the Hanford Site near Richland, Washington. Wastes from single shell tanks are being transferred to double shell tanks for safety reasons (some single shell tanks are leaking or are in danger of leaking), but the available double-shell tank space is limited.

The current System Plan for the Hanford Tank Farms (Rev. 4, Certa and Wells 2009) uses relaxed buoyant displacement gas release event (BDGRE) controls for deep sludge (i.e., high level waste [HLW]) tanks, which allows the tank farms to use more storage space, i.e., increase the sediment depth, in some of the double-shell tanks (DSTs). The relaxed BDGRE controls are based on preliminary analysis of a gas release model from van Kessel and van Kesteren (2002). Application of the van Kessel and van Kesteren model requires parametric information for the sediment, including the lateral earth pressure at rest and shear modulus. No lateral earth pressure at rest and shear modulus in situ measurements for Hanford sludge are currently available.

The two chemical sludge simulants will be used in follow-on work to experimentally measure the van Kessel and van Kesteren (2002) model parameters, lateral earth pressure at rest, and shear modulus. The simulants are selected via similarity to measured Hanford sludge chemical and physical properties, including liquid density, viscosity, and $\mathrm{pH}$, undissolved particle size and density, and slurry rheology to maximize the likelihood that the simulants will have similar lateral earth pressure at rest and shear modulus as Hanford sludge. Simulant 1 is selected from those Hanford sludge simulants that have previously been produced and characterized, and Simulant 2 is developed based upon the chemistry of a specific retrieval SST scenario. In Section 2, pertinent Hanford sludge properties are summarized, Simulant 1 is selected, and the chemistry for Simulant 2 is developed and presented. Simulant production is described in Section 3, and simulant property measurements are presented in Section 4. A summary is provided in Section 5.

Simulants 1 and 2 are shown to have chemical and physical properties that match well with all of the Hanford sludge parameters considered. The uniqueness of the simulants with respect to each other for some of the parameters considered is a beneficial outcome given the broad variation of Hanford waste. 



\section{Acronyms and Abbreviations}

$\begin{array}{ll}\text { BBI } & \text { Best Basis Inventory } \\ \text { BDGRE } & \text { buoyant displacement gas release event } \\ \text { DST } & \text { double-shell tank } \\ \text { EQL } & \text { estimated quantification limit } \\ \text { ESP } & \text { Environmental Simulation Program } \\ \text { HLW } & \text { high-level waste } \\ \text { KOH } & \text { potassium hydroxide } \\ \text { MDL } & \text { method detection limit } \\ \text { PEP } & \text { Pretreatment Engineering Platform } \\ \text { PNNL } & \text { Pacific Northwest National Laboratory } \\ \text { PSD } & \text { particle-size distribution } \\ \text { PSDD } & \text { particle size and density distribution } \\ \text { REDOX } & \text { reduction oxidation } \\ \text { RPP } & \text { River Protection Project } \\ \text { SEM } & \text { scanning electron microscopy } \\ \text { SST } & \text { single-shell tank } \\ \text { TOC } & \text { total organic carbon } \\ \text { UDS } & \text { undissolved solids } \\ \text { WTP } & \text { Hanford Tank Waste Treatment and Immobilization Plant } \\ \text { XRD } & \text { X-ray diffraction }\end{array}$





\section{Contents}

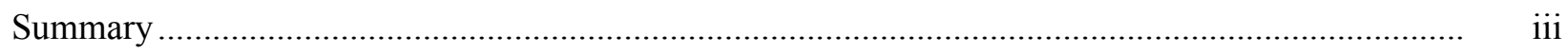

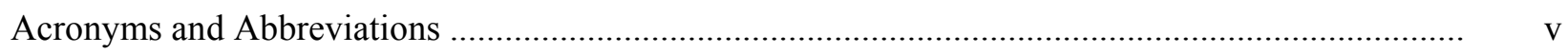

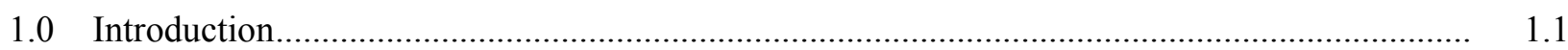

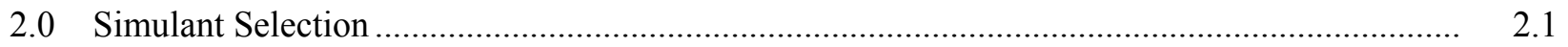

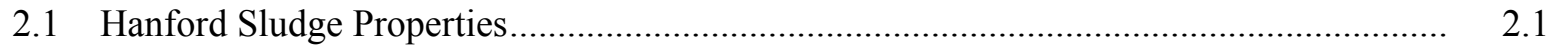

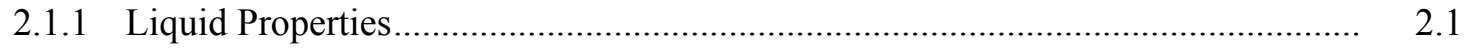

2.1.2 Slurry Properties ..................................................................................... 2.2

2.1.3 Hanford Sludge Waste Physical Property Summary ....................................... 2.11

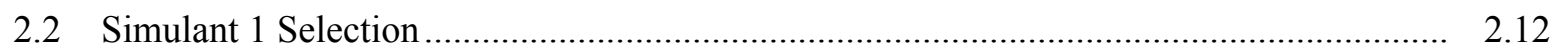

2.3 Simulant 2 Selection: Sludge-of-Interest Chemistry ................................................. 2.15

2.3.1 Use of ESP Model Predictions ...................................................................... 2.15

2.3.2 Combination of Inventories for the Four Tanks of Interest .............................. 2.17

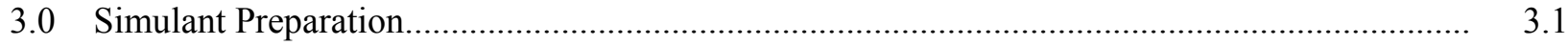

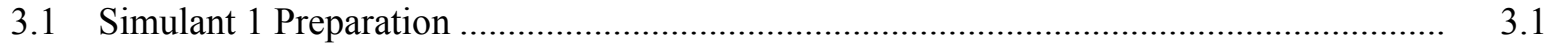

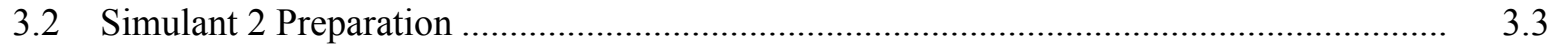

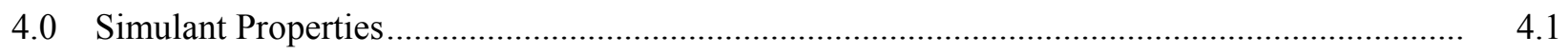

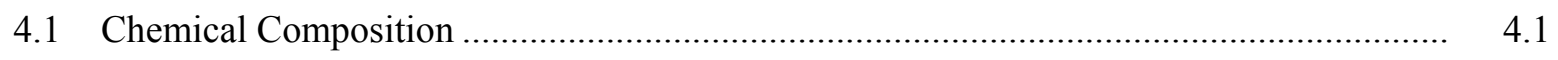

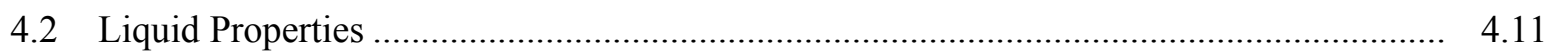

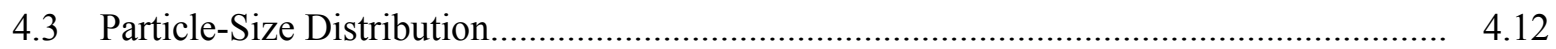

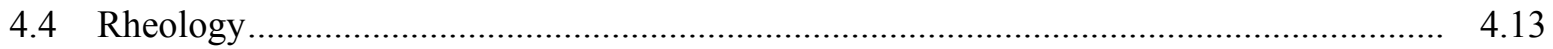

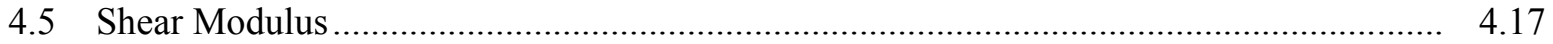

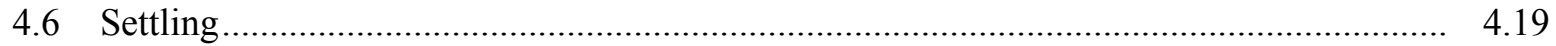

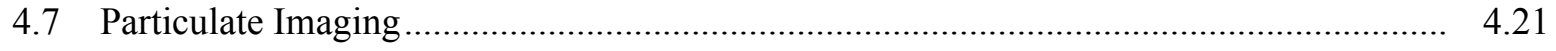

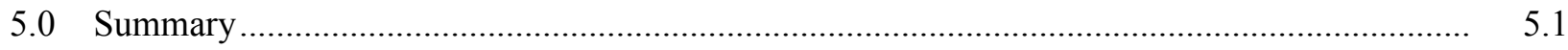

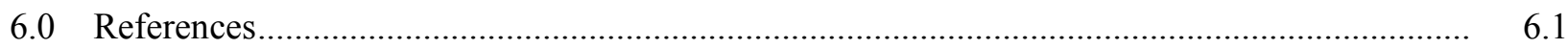

Appendix A: Recipe for Simulant 1 Iron-Bearing and Supernatant Simulant Component

Preparation

A.1

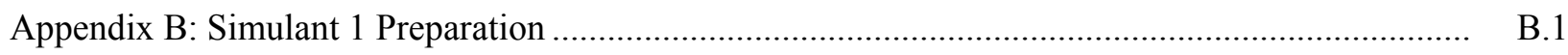

Appendix C: Recipe for Simulant 2 Preparation .................................................................... C. 1

Appendix D: Simulant 2 Liquid Viscosity Flow Curves ................................................................ D. 1

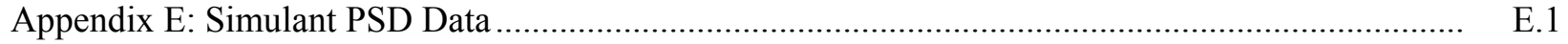

Appendix F: Simulant Slurry Rheology Flow Curves ............................................................. F.1 


\section{Figures}

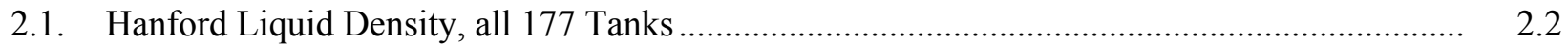

2.2. Hanford Liquid Density, all 81 Sludge Tanks ................................................................. 2.3

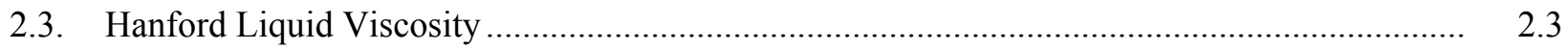

2.4. Hanford Sludge Tanks: Sediment UDS Volume and Mass Fractions .................................... 2.5

2.5. Bingham Rheological Model Data for Slurries from 18 Hanford Sludge Tanks, Volume

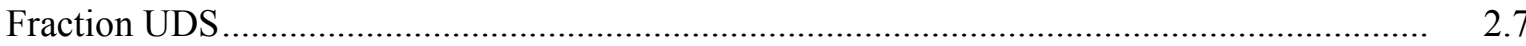

2.6. Bingham Rheological Model Data for Slurries from 18 Hanford Sludge Tanks, Mass

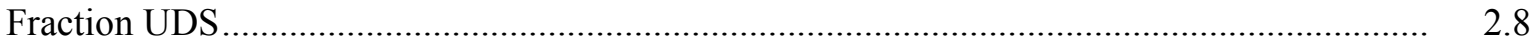

2.7. Probabilities for Bingham Consistency for Slurries from 18 Hanford Sludge Tanks, Mass Fraction UDS

2.8. Probabilities for Bingham Yield Stress for Slurries from 18 Hanford Sludge Tanks, Mass Fraction UDS

2.9. Sediment Shear Strength Data for 16 Hanford Sludge Tanks, Volume Fraction UDS ............. 2.10

2.10. Sediment Shear Strength Data for 15 Hanford Sludge Tanks, Mass Fraction UDS ................ 2.10

2.11. Probabilities for Sediment Shear Strength Data for 15 Hanford Sludge Tanks, Mass Fraction UDS

4.1. Simulant 1 XRD Results with Peak Identification .............................................................

4.2. Simulant 2 XRD Results with Peak Identification .............................................................. 4.9

4.3. Simulant 2 SEM EDS Elemental Analysis with Peak Identification...................................... 4.10

4.4. Location of SEM Elemental Analysis for Simulant 2 ................................................. 4.11

4.5. Simulant Bingham Parameters as Functions of Mass Fraction UDS ...................................... 4.14

4.6. Shear Strength as a Function of UDS Concentration ............................................................ 4.16

4.7. Shear Strength and Shear Modulus as a Function of UDS Concentration .............................. 4.19

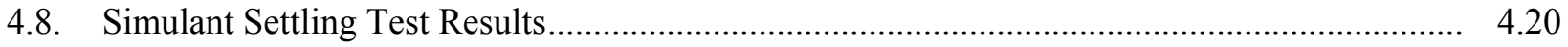

4.9. Calculated Simulant Settled Layer Shear Strength as a Function of Settling Time, Settling Data from 4.3

4.10. SEM Micrographs, Simulant 1 (Geeting et al. 2009). Magnification-A: 1,000×, B: $2,500 \times, C: 5,000 \times$, and D: $10,000 \times$

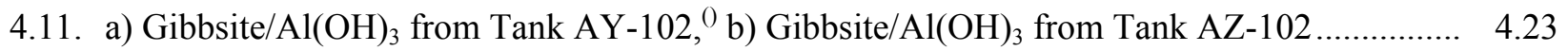

4.12. Boehmite/A1OOH Particles from Tank S-104 …................................................................. 4.23

4.13. a) $\mathrm{Fe}_{2} \mathrm{O}_{3}$ from Tank $\mathrm{C}-101^{\mathrm{O}}$; b) $\mathrm{Fe}_{2} \mathrm{O}_{3}$ from Tank $\mathrm{AN}-107$................................................ 4.24

4.14. SEM Micrographs, Simulant 2; a) Location 1, Magnification $1500 \times$, b) Location 1 ,

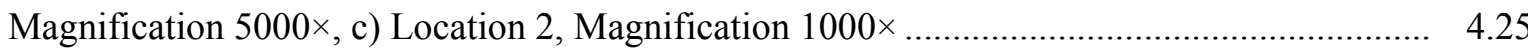

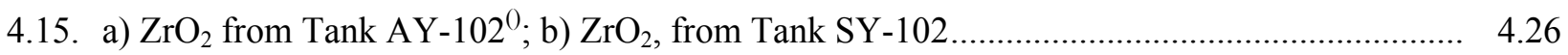




\section{Tables}

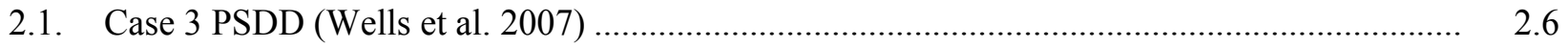

2.2. Hanford Sludge Waste Properties Summary .................................................................... 2.11

2.3. Simulant and Hanford Sludge Waste Properties Comparison .............................................. 2.13

2.4. ESP-Predicted Bulk Compositions for the Four Tanks ....................................................... 2.19

2.5. ESP-Predicted Liquid-Phase Compositions for the Four Tanks............................................. 2.20

2.6. Four-Tank Waste Mixture Composition, from Summing ESP Predictions.............................. 2.21

2.7. Four-Tank Waste Primary (Mass Fraction $>0.5$ ) Solid Phase Compound Composition, from Summing ESP Predictions ....................................................................................... 2.22

3.1. Postulated Composition of Iron-Rich Sludge ................................................................ 3.2

3.2. Chemical Components Used to Produce Supernate Simulant ............................................... 3.2

4.1. Liquid Phase Composition, Simulant 1 .................................................................................

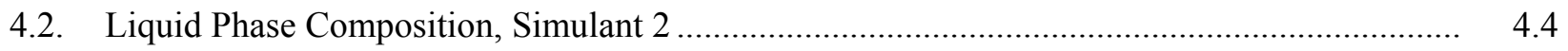

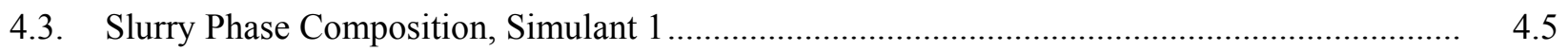

4.4. Slurry Phase Composition, Simulant 2 ….................................................................... 4.6

4.5. Selected Postulated Primary UDS Solid Phase Compounds .................................................. 4.7

4.6. Simulant 2 SEM EDS Elemental Analysis with Peak Quantification ...................................... 4.10

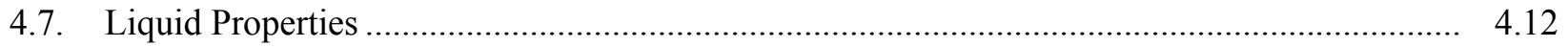

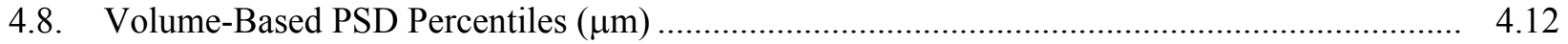

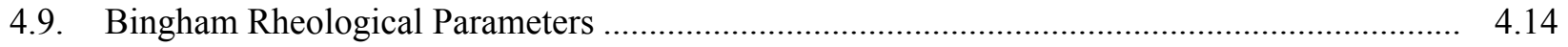

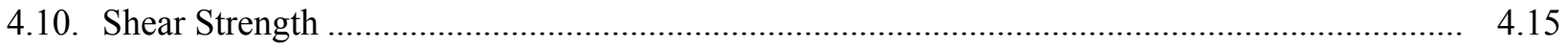

4.11. Bingham Yield Stress and Shear-Strength Comparison ................................................. 4.17

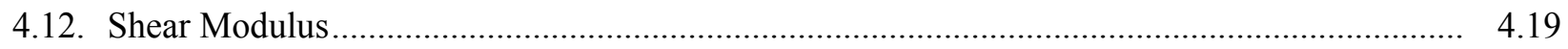





\subsection{Introduction}

Radioactive wastes composed of liquid (water and dissolved solids) and settled undissolved solids (UDS) are stored in 177 large underground storage tanks on the Hanford Site. The 177 storage tanks include 149 single shell tanks (SSTs) and 28 double shell tanks (DSTs). Waste will be retrieved from the SSTs to interim storage in the DSTs. Certa and Wells (2009) (System Plan [Rev. 4]) report that the Baseline Case, which, in part, describes how the River Protection Project (RPP) mission ${ }^{(a)}$ could be achieved given an underlying set of assumptions, shows that there is adequate DST space to meet the near-term success criteria for specific SST retrieval. Subsequently, however, there will be minimal DST space available to proceed with additional SST retrievals. Management of DST space is thus a key issue.

The UDS management strategy in the previous System Plan (Rev. 3) followed the existing buoyant displacement gas release event (BDGRE) controls (Weber 2008). The depth of settled UDS or sediment accumulated in a DST, and therefore the inventory of UDS that may be stored in a DST, is limited by these controls.

Hanford radioactive wastes generate flammable gases (Weber 2008). Hydrogen is the primary flammable component of the generated gas (Meyer and Stewart 2001). Flammable gas generation by itself is not a hazard if the generated gas is released continuously as fast as it is generated. In some DST wastes, however, specifically those with deep layers of supernatant liquid and sediment (sediment settled UDS and interstitial liquid), the generated gas can accumulate in the sediment until a portion of the sediment accumulates gas such that it becomes sufficiently buoyant to overcome its weight and the strength of the surrounding material restraining it. The sufficiently buoyant portion then rises through the supernate, and the resultant expansion of the retained gas yields the retaining material such that a fraction of the retained gas is released, and the remaining non-buoyant material sinks back to the sediment (e.g., Wells et al. 2002, Meyer and Stewart 2001, Hedengren et al. 2000). This gas release process defines a BDGRE.

The current System Plan (Rev. 4, Certa and Wells 2009) uses relaxed BDGRE controls for deep sludge (i.e., high level waste [HLW]) tanks, which allow the tank farms to use more storage space, i.e., increase the sediment depth, in some of the DSTs. The relaxed BDGRE controls are based on preliminary analysis of a gas release model from van Kessel and van Kesteren (2002). Applying the van Kessel and van Kesteren model requires parametric information for the sediment, including the undrained shear strength, void ratio, UDS and liquid density, lateral earth pressure at rest, shear modulus, average floc size, and the undisturbed channel radius. Some of these parameters are known for Hanford sludge sediment. The objective of the current work is to select or develop two chemical sludge simulants to be used in follow-on work to experimentally measure the van Kessel and van Kesteren model parameters lateral earth pressure at rest and shear modulus, for which no Hanford sludge measurements are currently available.

(a) The RPP mission is to retrieve and treat Hanford's tank waste and close the tank farms to protect the Columbia River. 
The van Kessel and van Kesteren model sediment parameters undrained shear strength, ${ }^{(a)}$ UDS and liquid density, lateral earth pressure at rest, shear modulus, and average floc (particle) size have interdependence. A material's shear strength is a function of the UDS loading (e.g., Gauglitz et al. 2009, Poloski et al. 2007, Shatzmann et al. 2003, Turian et al. 2002, Ancey and Jorrot 2001, Zhou et al. 1999, Channell and Zukoski 1997, and Buscal et al. 1987), which in turn can be expressed as a function of the UDS and liquid density. The shear strength is also a function of the particle size and distribution (e.g., Shatzmann et al. 2003, Turian et al. 2002, Naeini and Baziar 2004, Ancey and Jorrot 2001, Zhou et al. 1999, and Buscal et al. 1987).

Other sediment parameters that affect its shear strength include $\mathrm{pH}$ and particle shape. The $\mathrm{pH}$ of the Hanford waste is intentionally kept basic to inhibit corrosion in the carbon steel vessels. The $\mathrm{pH}$ of a liquid and UDS system has been shown to affect the material's shear strength by Ancey and Jorrot (2001) and Zhou et al. (1999). Ancey and Jorrot (2001) found that the more irregular the particle shape of the larger particles, the higher the yield stress. The retained gas content also affects a material's measured shear strength (Gauglitz et al. 1995); the effect of gas content will not be addressed further in this report.

The shear modulus is the slope of the initial linear portion of a shear stress-shear strain curve and is a measure of the material's stiffness in shear. The shear modulus of a material may thus be expected to be dependent on the same properties as the shear strength. Alderman et al. (1991) and Buscal et al. (1987) show increased shear modulus with increasing UDS concentration, and Alderman et al. report on the dependence of the shear modulus with gelation time (quiescent time of the sample).

The lateral earth pressure at rest is the ratio of the lateral (horizontal) pressure to the vertical pressure when the lateral strain is zero (Craig 2004). It is thus reasonable that the material properties affecting pressure (stress) influence the lateral earth pressure. For example, the lateral earth pressure at rest is shown in the literature to vary by a factor of approximately two from loose sand to clay soils. A common indirect methodology to determine the lateral earth pressure at rest uses the empirical relation of Jaky (1948), which uses the friction angle, itself affected by the material properties that affect stress.

As noted, there are no in situ data for the lateral earth pressure at rest or shear modulus for Hanford sediment. Although these soil mechanics properties can be measured in situ (e.g., dilatometer test or borehole pressuremeter test for lateral earth pressure and ultrasonic techniques for the shear modulus), the Hanford waste environment is such that application of in situ methodologies is challenging. Methodologies do exist to determine the shear modulus from shear vane data (Alderman et al. 1991, Barnes and Nguyen 2001), and shear vane testing had been done on waste from 22 Hanford tanks (16 of which are sludge tanks, Gauglitz et al. 2009).

As previously stated, the objective of the current work is to select or develop two chemical sludge simulants to be used in follow-on work to experimentally measure lateral earth pressure at rest and shear modulus representative of Hanford sludge sediment. The simulants are selected via similarity to measured Hanford sludge chemical and physical properties, including liquid density, viscosity, and $\mathrm{pH}$, UDS particle size and density, and slurry rheology to maximize the likelihood that the simulants will have similar lateral earth pressure at rest and shear modulus as Hanford sludge. Simulant 1 is selected from

(a) The shear vane technique is a common methodology in the literature used to directly measure a materials yield stress in shear or shear strength. Since a shear vane test is conducted relatively rapidly, it may be expected that a shear strength determined via a shear vane is undrained. 
those Hanford sludge simulants that have previously been produced and characterized, and Simulant 2 is developed based upon the chemistry of a specific retrieval SST scenario. In Section 2, pertinent Hanford sludge properties are summarized, Simulant 1 is selected, and the chemistry for Simulant 2 is developed and presented. Simulant production is described in Section 3, and simulant property measurements are presented in Section 4. A summary is provided in Section 5. 



\subsection{Simulant Selection}

As described in Section 1, the sludge parameters of interest to be measured in the follow-on work, lateral earth pressure at rest and shear modulus, may be expected to be influenced by the chemical and physical properties of the sludge material. Two chemical simulants, representing the Hanford sludge as a whole and a specific SST retrieval scenario, are considered.

The first simulant, Simulant 1, is chosen from Hanford sludge simulants that have previously been produced and characterized. The selection is based on comparison to actual Hanford sludge chemical and physical properties, including liquid density, viscosity, and $\mathrm{pH}$, UDS particle size and density, and slurry rheology. Simulant 2 is developed based upon the chemistry of the specific SST retrieval scenario with comparison of the resultant physical properties of the simulant to those of the Hanford sludge as for Simulant 1 .

With the exception of particle shape, the sediment parameters expected to affect the lateral earth pressure at rest and shear modulus discussed in Section 1 are addressed in the actual Hanford sludge chemical and physical properties. Quantification of the particle shape of Hanford sludge has not been made per se. However, images of Hanford waste particles for the primary sludge solid phase compounds are shown in Wells et al. (2007). Particle shape may be observed to be unique and varied with the solid phase compound. Thus, the simulants are selected and developed such that the chemical solid phase compositions are similar to Hanford sludge.

In Section 2.1, measured Hanford sludge properties are summarized. Significant figures and uncertainties were not tracked nor reported. The selection of Simulant 1 is presented in Section 2.2, and the sludge-of-interest chemistry for Simulant 2 is provided in Section 2.3.

\subsection{Hanford Sludge Properties}

Characterization of the liquid (water and dissolved solids), UDS, slurry, and settled UDS sediment of the Hanford high level waste (HLW; i.e., sludge) is made to establish expected property ranges.

\subsubsection{Liquid Properties}

The Hanford liquid waste is composed of water and dissolved solids. Liquid properties considered include the liquid density, viscosity, and $\mathrm{pH}$. Those waste tanks with larger concentrations of soluble UDS (i.e., the "saltcake" tanks) typically have a higher concentration of dissolved solids in the liquid than the HLW sludge tanks, resulting in a higher liquid density. The cumulative liquid density distributions for all 177 Hanford waste tanks and the 81 sludge tanks from Weber (2008) are provided in Figure 2.1 and Figure 2.2, respectively. The probability is strictly based on tank count. The median and $95^{\text {th }}$ percentile for the liquid density are 1.1 and $1.47 \mathrm{~g} / \mathrm{mL}$, respectively, for all 177 tanks, and 1.1 and 1.3 $\mathrm{g} / \mathrm{mL}$, respectively, for the 81 sludge tanks.

Liquid viscosity data are available for a limited number of tanks. The liquid viscosity data for seven saltcake and two sludge tanks from Poloski et al. (2008) as a function of liquid density and temperature are provided in Figure 2.3. The liquid viscosity at the median liquid density for the 177 tanks is indicated 
to be less than $2.5 \mathrm{cP}$, and, at the $95^{\text {th }}$ percentile liquid density for the 177 tanks at a temperature of 25 to $35^{\circ} \mathrm{C}$, may approach $20 \mathrm{cP}$. No viscosity data beyond the $85^{\text {th }}$ percentile liquid density of the sludge tanks, corresponding to approximately $1.24 \mathrm{~g} / \mathrm{mL}$, are reported in Poloski et al. (2007). Wells et al. (2007) used a liquid density of $1.2 \mathrm{~g} / \mathrm{mL}$ (corresponding approximately to the $84^{\text {th }}$ percentile liquid density for the Hanford sludge tanks, Figure 2.2) and a liquid viscosity of $2 \mathrm{cP}$ (from five HLW sludge tanks) to represent the liquid properties of the Hanford sludge tanks.

The median liquid $\mathrm{pH}, 13.2$, is determined from the sludge tank liquid data available from TWINS. (a) The liquid $\mathrm{pH}$ data (244 measurements) range from 7 to 13.7 .

\subsubsection{Slurry Properties}

Hanford sludge slurries are composed of liquid and UDS. Slurry properties of interest include the UDS concentration, UDS composition, particle size and density, and sludge rheology.

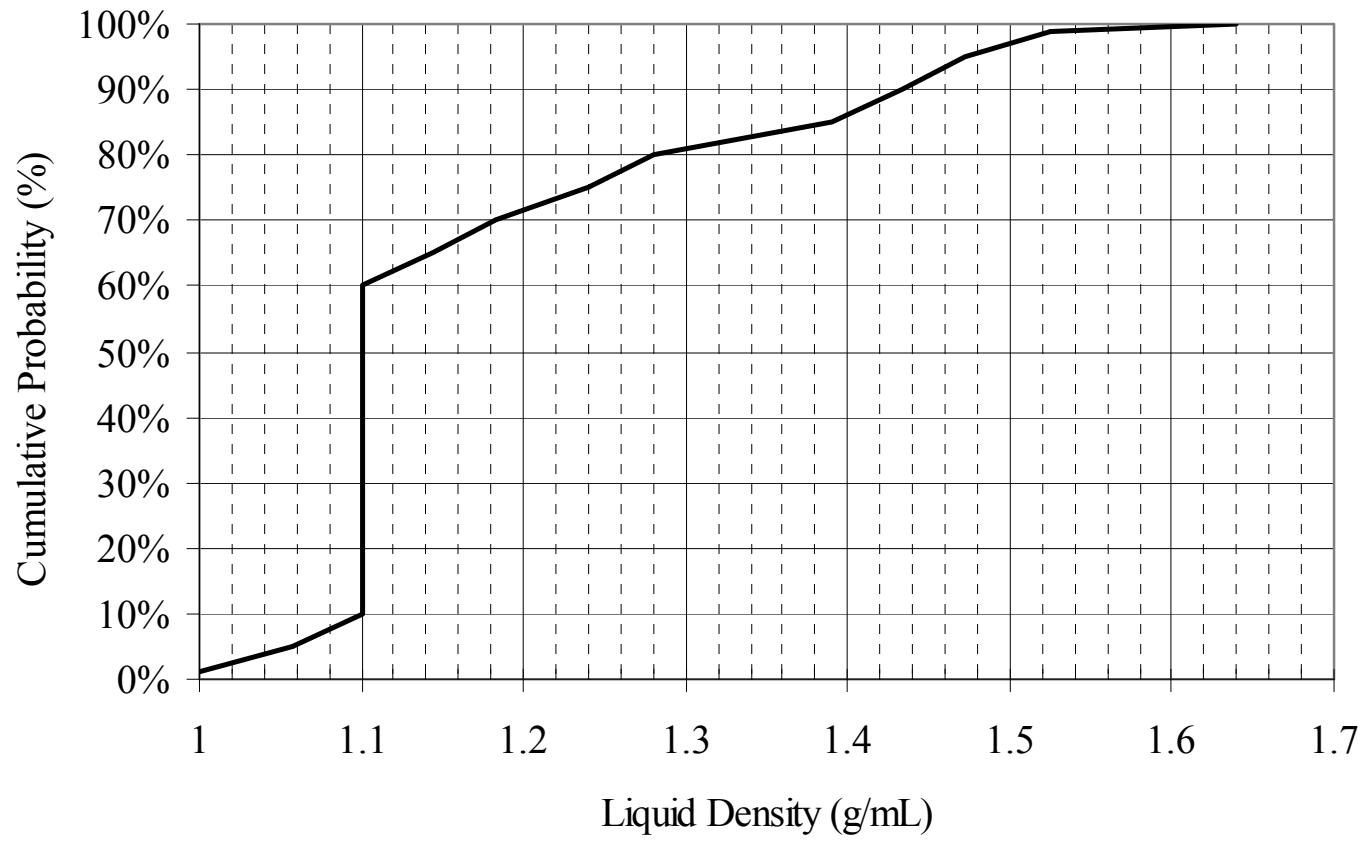

Figure 2.1. Hanford Liquid Density, all 177 Tanks

(a) TWINS: Tank Waste Information System database. http://twins.pnl.gov/twins3/twins.htm 


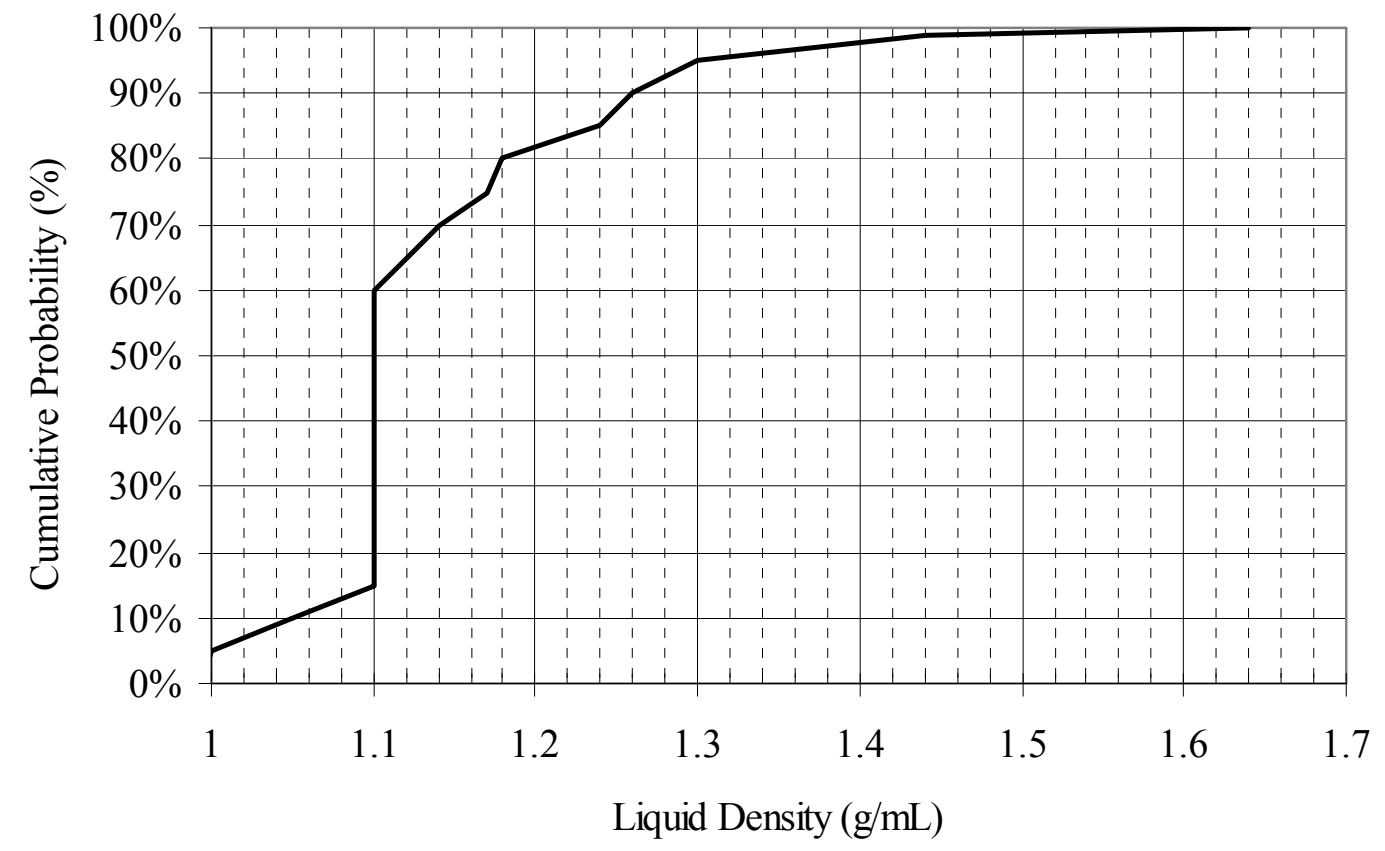

Figure 2.2. Hanford Liquid Density, all 81 Sludge Tanks

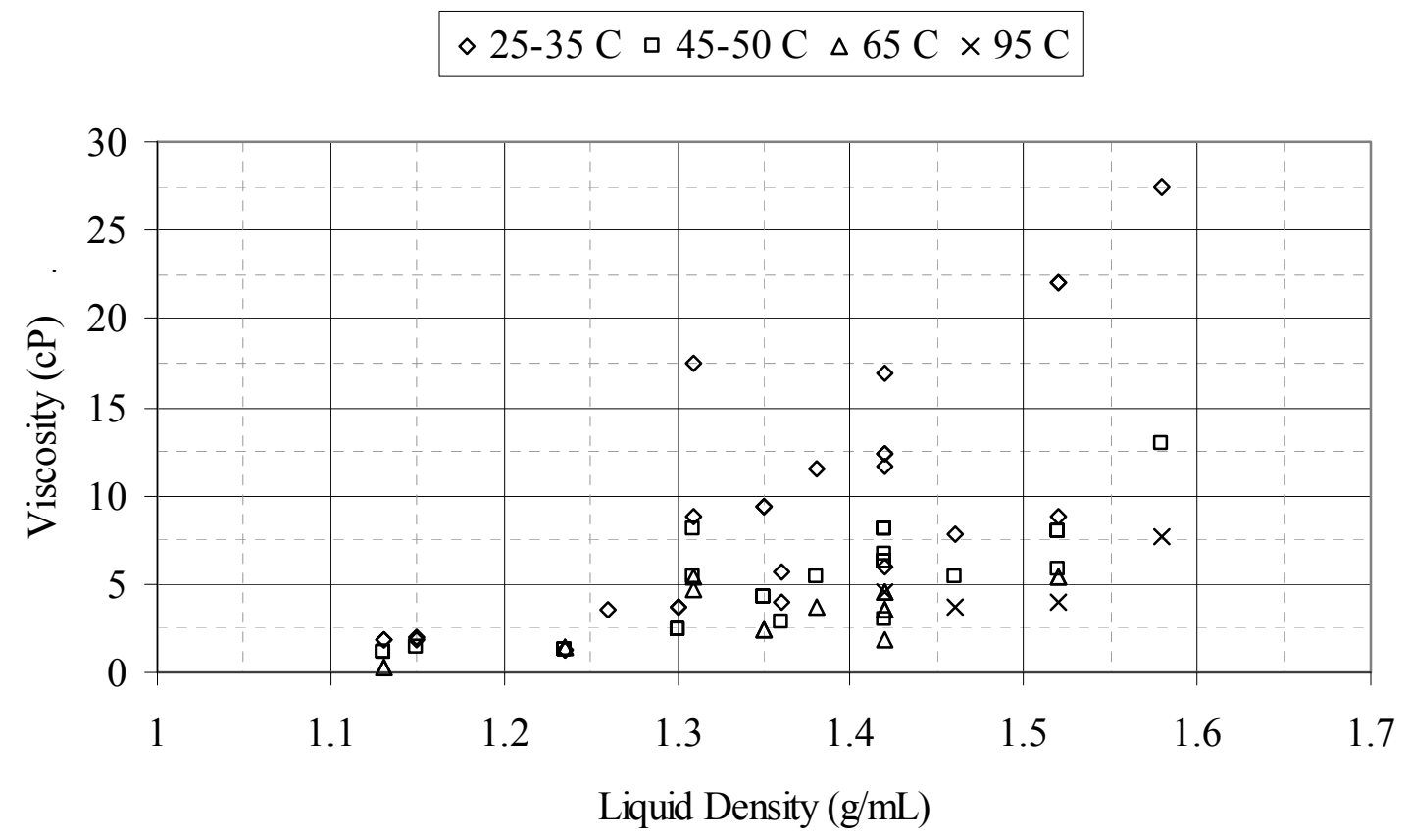

Figure 2.3. Hanford Liquid Viscosity 


\subsubsection{Slurry UDS Concentration}

The UDS concentration in settled sludge sediment may be expressed on a volume basis, and can be determined from

$$
\phi_{\mathrm{S}}=\frac{\rho_{\mathrm{B}}-\rho_{\mathrm{L}}}{\rho_{\mathrm{S}}-\rho_{\mathrm{L}}}
$$

where $\rho_{\mathrm{B}}$ is the bulk sediment density, $\rho_{\mathrm{S}}$ is the UDS density, and $\rho_{\mathrm{L}}$ is the liquid density. The UDS mass fraction can be computed from the volume fraction as

$$
\mathrm{w}_{\mathrm{S}}=\phi_{\mathrm{S}} \frac{\rho_{\mathrm{S}}}{\rho_{\mathrm{B}}}
$$

The volume and mass UDS fractions are evaluated for the sediments in Hanford sludge tanks. With the tank-specific UDS densities from the $\operatorname{ESP}^{(a)}$ chemical thermodynamic model results used by Wells et al. (2007), ${ }^{(b)}$ and sediment and liquid densities from Weber (2008), the cumulative probabilities of the volume and mass UDS fractions for the sediment in the 81 Hanford sludge tanks are as indicated in Figure 2.4. ${ }^{(\mathrm{c})}$ The probability is strictly based on tank count. The median and $95^{\text {th }}$ percentile for the UDS volume fraction are approximately 0.31 and 0.61 , respectively. The UDS mass fraction is approximately 0.53 and 0.73 at the median and $95^{\text {th }}$ percentiles, respectively.

\subsubsection{UDS Particulate Composition, Size, and Density}

UDS particulate can be characterized by a particle size and density distribution (PSDD). Wells et al. (2007) present PSDDs based on the combination of particle-size distributions (PSDs) of 19 Hanford sludge (i.e., non-saltcake waste) tanks and the insoluble solid-phase compounds from all 177 Hanford tanks.

The Case 3 PSDD of Wells et al. (2007), representing the total insoluble UDS inventory (i.e., sludge solids) at Hanford, is considered. The Case 3 PSDD is recommended by Hanford Tank Waste Treatment and Immobilization Plant (WTP) project memorandum CCN 186332, from AW Etchells, Dupont Technology Consulting, to SA Saunders, Bechtel National, Inc., on January 29, 2007, "Comments on the Input Particle Size Report," as “...the most accurate and most conservative” approach. The Case 3 approach assigns the primary particulate density of the solid phase compounds (i.e., crystal density) to the particulate, independent of particle size. As such, solids particle density reduction (by agglomeration) below the primary crystal density is not accounted for. As discussed in Wells et al. (2007), this approach does not represent the actual phenomenon of particulate agglomeration, but was selected because it

(a) ESP was supplied and developed by OLI Systems, Inc., Morris Plains, NJ.

(b) Sodium salts are included in the current analysis. Densities are on a dry-solid, crystal density basis.

(c) 81 sludge tanks is specified in Weber (2008). 
provides an upper-bound for possible particle size and density, and it removes the significant uncertainty of quantifying the fractal dimension relating the agglomeration size and density.

The Case 3 PSDD of Wells et al. (2007) is a 3-dimensional matrix of volume-based probability of each solid-phase compound in a PSD "bin" and its density in that bin, Table 2.1. The PSD bins represent the upper and lower size limit of the particles associated with a given bin. Thus, the volume fraction of insoluble solid particulate at a given size and density is specified for the Hanford waste volume. For example, in Table 2.1, it can be seen that gibbsite, $\mathrm{Al}(\mathrm{OH})_{3}$, comprises $51.5 \%$ of the Hanford insoluble solid particulate by volume, and that gibbsite particles greater than 7.7 and less than or equal to $10 \mu \mathrm{m}$ have a density of $2.42 \mathrm{~g} / \mathrm{mL}$ and comprise $4 \%$ of the solids by volume.

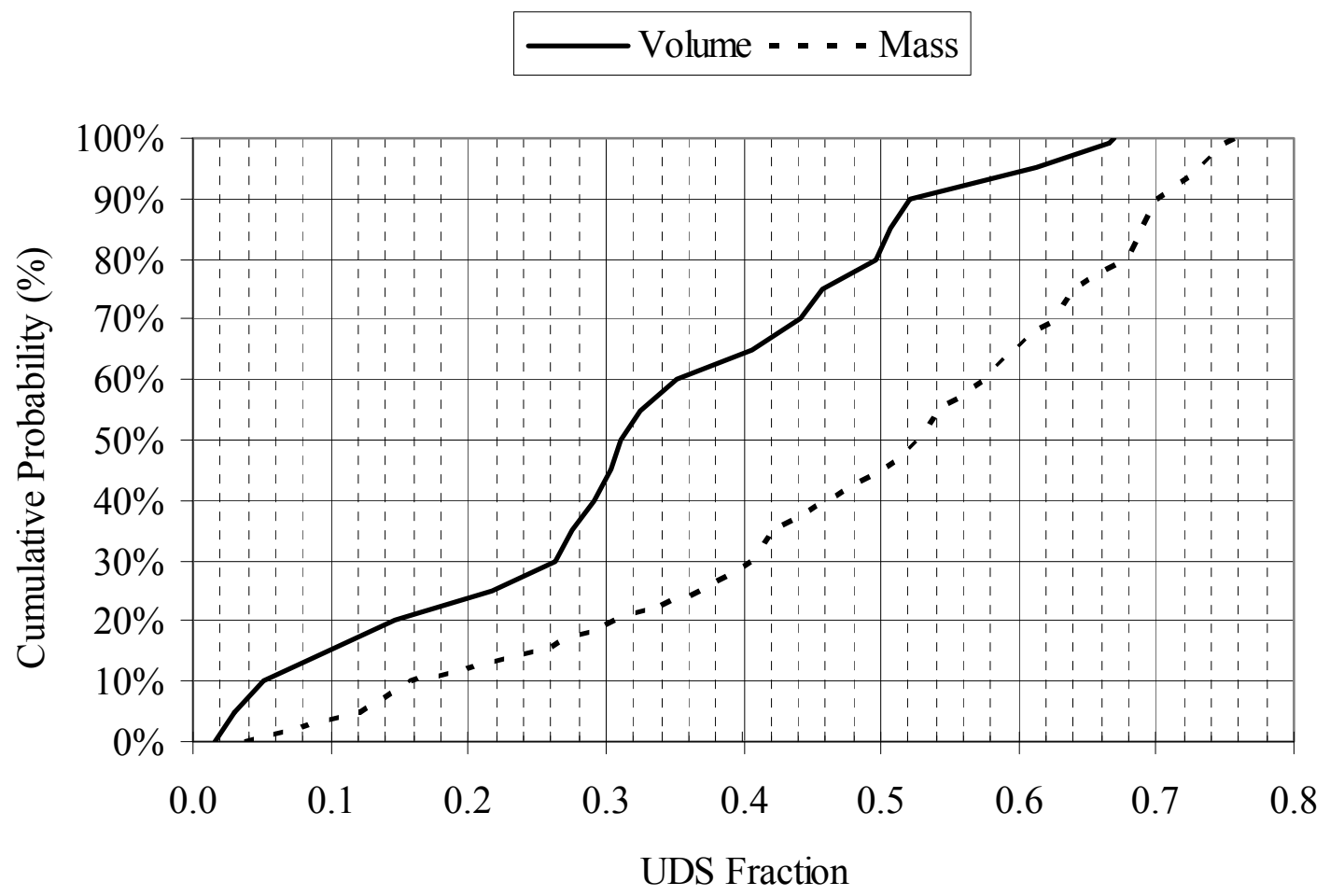

Figure 2.4. Hanford Sludge Tanks: Sediment UDS Volume and Mass Fractions 
Table 2.1. Case 3 PSDD (Wells et al. 2007)

\begin{tabular}{|c|c|c|c|c|c|c|c|c|c|c|c|c|c|c|c|c|c|}
\hline \multirow{3}{*}{$\begin{array}{l}\text { Particle } \\
\text { Size } \\
(\mu \mathrm{m})\end{array}$} & \multicolumn{16}{|c|}{ Solid-Phase Compounds and Density $(\mathrm{g} / \mathrm{mL})$} & \multirow{3}{*}{$\begin{array}{c}\text { Total } \\
\text { Volume } \\
\text { Fraction }\end{array}$} \\
\hline & $\begin{array}{c}\mathrm{Al}(\mathrm{OH})_{3} \\
2.42 \\
\end{array}$ & $\begin{array}{c}\left(\mathrm{NaAlSiO}_{4}\right)_{6} \\
\left(\mathrm{NaNO}_{3}\right)_{1.6^{\bullet}} \\
2 \mathrm{H}_{2} \mathrm{O} \\
2.365\end{array}$ & $\begin{array}{c}\mathrm{AlOOH} \\
3.01 \\
\end{array}$ & $\begin{array}{c}\mathrm{NaAlCO}_{3} \\
(\mathrm{OH})_{2} \\
2.42 \\
\end{array}$ & $\begin{array}{c}\mathrm{Fe}_{2} \mathrm{O}_{3} \\
5.24 \\
\end{array}$ & $\begin{array}{c}\mathrm{Ca}_{5} \mathrm{OH} \\
\left(\mathrm{PO}_{4}\right)_{3} \\
3.14 \\
\end{array}$ & $\begin{array}{c}\mathrm{Na}_{2} \mathrm{U}_{2} \mathrm{O}_{7} \\
5.617 \\
\end{array}$ & $\begin{array}{c}\mathrm{ZrO}_{2} \\
5.68 \\
\end{array}$ & $\begin{array}{c}\mathrm{Bi}_{2} \mathrm{O}_{3} \\
8.9\end{array}$ & $\begin{array}{c}\mathrm{SiO}_{2} \\
2.6\end{array}$ & $\begin{array}{c}\mathrm{Ni}(\mathrm{OH})_{2} \\
4.1\end{array}$ & $\begin{array}{c}\mathrm{MnO}_{2} \\
5.026\end{array}$ & $\begin{array}{l}\mathrm{CaF}_{2} \\
3.18\end{array}$ & $\begin{array}{c}\mathrm{LaPO}_{4} \\
2 \mathrm{H}_{2} \mathrm{O} \\
6.51\end{array}$ & $\begin{array}{c}\mathrm{Ag}_{2} \mathrm{CO}_{3} \\
6.077\end{array}$ & $\begin{array}{l}\mathrm{PuO}_{2} \\
11.43\end{array}$ & \\
\hline & \multicolumn{16}{|c|}{ Solid Volume Fraction } & \\
\hline 0.22 & $1 \mathrm{E}-04$ & 5E-05 & $3 \mathrm{E}-05$ & $3 \mathrm{E}-05$ & $1 \mathrm{E}-05$ & $6 \mathrm{E}-06$ & $5 \mathrm{E}-06$ & $3 \mathrm{E}-06$ & $2 \mathrm{E}-06$ & $2 \mathrm{E}-06$ & $2 \mathrm{E}-06$ & $2 \mathrm{E}-06$ & $7 \mathrm{E}-07$ & $4 \mathrm{E}-07$ & $3 \mathrm{E}-08$ & $4 \mathrm{E}-09$ & 2E-04 \\
\hline 0.28 & 3E-04 & $1 \mathrm{E}-04$ & $6 \mathrm{E}-05$ & $6 \mathrm{E}-05$ & $2 \mathrm{E}-05$ & $1 \mathrm{E}-05$ & $9 \mathrm{E}-06$ & $6 \mathrm{E}-06$ & $5 \mathrm{E}-06$ & $4 \mathrm{E}-06$ & $3 \mathrm{E}-06$ & $3 \mathrm{E}-06$ & $1 \mathrm{E}-06$ & $8 \mathrm{E}-07$ & $5 \mathrm{E}-08$ & $8 \mathrm{E}-09$ & 6E-04 \\
\hline 0.36 & $6 \mathrm{E}-04$ & $2 \mathrm{E}-04$ & $1 \mathrm{E}-04$ & $1 \mathrm{E}-04$ & $5 \mathrm{E}-05$ & $2 \mathrm{E}-05$ & $2 \mathrm{E}-05$ & $1 \mathrm{E}-05$ & $1 \mathrm{E}-05$ & $8 \mathrm{E}-06$ & $7 \mathrm{E}-06$ & $7 \mathrm{E}-06$ & $3 \mathrm{E}-06$ & $2 \mathrm{E}-06$ & $1 \mathrm{E}-07$ & $2 \mathrm{E}-08$ & $1 \mathrm{E}-03$ \\
\hline 0.46 & $5 \mathrm{E}-05$ & $2 \mathrm{E}-05$ & $1 \mathrm{E}-05$ & $1 \mathrm{E}-05$ & $4 \mathrm{E}-06$ & $2 \mathrm{E}-06$ & $2 \mathrm{E}-06$ & $1 \mathrm{E}-06$ & $9 \mathrm{E}-07$ & 7E-07 & $6 \mathrm{E}-07$ & $6 \mathrm{E}-07$ & $2 \mathrm{E}-07$ & 1E-07 & 1E-08 & $1 \mathrm{E}-09$ & $1 \mathrm{E}-04$ \\
\hline 0.60 & $2 \mathrm{E}-03$ & $5 \mathrm{E}-04$ & 3E-04 & 3E-04 & $1 \mathrm{E}-04$ & $6 \mathrm{E}-05$ & $5 \mathrm{E}-05$ & $3 \mathrm{E}-05$ & $2 \mathrm{E}-05$ & 2E-05 & $2 \mathrm{E}-05$ & $2 \mathrm{E}-05$ & 7E-06 & $4 \mathrm{E}-06$ & 3E-07 & $4 \mathrm{E}-08$ & $3 \mathrm{E}-03$ \\
\hline 0.77 & $8 \mathrm{E}-03$ & 3E-03 & $2 \mathrm{E}-03$ & $1 \mathrm{E}-03$ & $6 \mathrm{E}-04$ & $3 \mathrm{E}-04$ & $2 \mathrm{E}-04$ & $2 \mathrm{E}-04$ & $1 \mathrm{E}-04$ & $1 \mathrm{E}-04$ & $8 \mathrm{E}-05$ & $8 \mathrm{E}-05$ & $3 \mathrm{E}-05$ & 2E-05 & $1 \mathrm{E}-06$ & $2 \mathrm{E}-07$ & $2 \mathrm{E}-02$ \\
\hline 1.0 & $2 \mathrm{E}-02$ & $5 \mathrm{E}-03$ & 3E-03 & $3 \mathrm{E}-03$ & $1 \mathrm{E}-03$ & 6E-04 & $5 \mathrm{E}-04$ & $3 \mathrm{E}-04$ & $2 \mathrm{E}-04$ & $2 \mathrm{E}-04$ & $2 \mathrm{E}-04$ & $2 \mathrm{E}-04$ & $7 \mathrm{E}-05$ & $4 \mathrm{E}-05$ & $3 \mathrm{E}-06$ & $4 \mathrm{E}-07$ & $3 \mathrm{E}-02$ \\
\hline 1.3 & 2E-02 & $6 \mathrm{E}-03$ & $4 \mathrm{E}-03$ & $4 \mathrm{E}-03$ & $2 \mathrm{E}-03$ & $8 \mathrm{E}-04$ & $6 \mathrm{E}-04$ & $4 \mathrm{E}-04$ & 3E-04 & 3E-04 & $2 \mathrm{E}-04$ & $2 \mathrm{E}-04$ & $9 \mathrm{E}-05$ & $5 \mathrm{E}-05$ & $4 \mathrm{E}-06$ & $5 \mathrm{E}-07$ & $4 \mathrm{E}-02$ \\
\hline 1.7 & 3E-02 & $1 \mathrm{E}-02$ & 7E-03 & $6 \mathrm{E}-03$ & $3 \mathrm{E}-03$ & $1 \mathrm{E}-03$ & $1 \mathrm{E}-03$ & 7E-04 & $5 \mathrm{E}-04$ & 4E-04 & $4 \mathrm{E}-04$ & $3 \mathrm{E}-04$ & $1 \mathrm{E}-04$ & $8 \mathrm{E}-05$ & $6 \mathrm{E}-06$ & $8 \mathrm{E}-07$ & $6 \mathrm{E}-02$ \\
\hline 2.2 & $1 \mathrm{E}-02$ & $5 \mathrm{E}-03$ & $3 \mathrm{E}-03$ & $3 \mathrm{E}-03$ & $1 \mathrm{E}-03$ & 5E-04 & $4 \mathrm{E}-04$ & $3 \mathrm{E}-04$ & $2 \mathrm{E}-04$ & $2 \mathrm{E}-04$ & $1 \mathrm{E}-04$ & $1 \mathrm{E}-04$ & $6 \mathrm{E}-05$ & $4 \mathrm{E}-05$ & $3 \mathrm{E}-06$ & $4 \mathrm{E}-07$ & $2 \mathrm{E}-02$ \\
\hline 2.8 & 4E-02 & $1 \mathrm{E}-02$ & 7E-03 & $6 \mathrm{E}-03$ & $3 \mathrm{E}-03$ & $1 \mathrm{E}-03$ & $1 \mathrm{E}-03$ & 7E-04 & $6 \mathrm{E}-04$ & $5 \mathrm{E}-04$ & $4 \mathrm{E}-04$ & $4 \mathrm{E}-04$ & $2 \mathrm{E}-04$ & 9E-05 & 6E-06 & $9 \mathrm{E}-07$ & 7E-02 \\
\hline 3.6 & $5 \mathrm{E}-02$ & $2 \mathrm{E}-02$ & $1 \mathrm{E}-02$ & $9 \mathrm{E}-03$ & $4 \mathrm{E}-03$ & $2 \mathrm{E}-03$ & $1 \mathrm{E}-03$ & $1 \mathrm{E}-03$ & 7E-04 & 6E-04 & $5 \mathrm{E}-04$ & $5 \mathrm{E}-04$ & $2 \mathrm{E}-04$ & 1E-04 & $9 \mathrm{E}-06$ & $1 \mathrm{E}-06$ & $1 \mathrm{E}-01$ \\
\hline 4.6 & 3E-02 & 1E-02 & $6 \mathrm{E}-03$ & $6 \mathrm{E}-03$ & $3 \mathrm{E}-03$ & $1 \mathrm{E}-03$ & $1 \mathrm{E}-03$ & 7E-04 & $5 \mathrm{E}-04$ & 4E-04 & $3 \mathrm{E}-04$ & 3E-04 & $1 \mathrm{E}-04$ & $8 \mathrm{E}-05$ & $6 \mathrm{E}-06$ & $8 \mathrm{E}-07$ & $6 \mathrm{E}-02$ \\
\hline 6.0 & $4 \mathrm{E}-02$ & $1 \mathrm{E}-02$ & $9 \mathrm{E}-03$ & $8 \mathrm{E}-03$ & $3 \mathrm{E}-03$ & $2 \mathrm{E}-03$ & $1 \mathrm{E}-03$ & $9 \mathrm{E}-04$ & $7 \mathrm{E}-04$ & $6 \mathrm{E}-04$ & $5 \mathrm{E}-04$ & $4 \mathrm{E}-04$ & $2 \mathrm{E}-04$ & $1 \mathrm{E}-04$ & $8 \mathrm{E}-06$ & $1 \mathrm{E}-06$ & $8 \mathrm{E}-02$ \\
\hline 7.7 & $5 \mathrm{E}-02$ & 2E-02 & $1 \mathrm{E}-02$ & $9 \mathrm{E}-03$ & $4 \mathrm{E}-03$ & $2 \mathrm{E}-03$ & $2 \mathrm{E}-03$ & $1 \mathrm{E}-03$ & $8 \mathrm{E}-04$ & 7E-04 & $5 \mathrm{E}-04$ & $5 \mathrm{E}-04$ & $2 \mathrm{E}-04$ & 1E-04 & $9 \mathrm{E}-06$ & $1 \mathrm{E}-06$ & $1 \mathrm{E}-01$ \\
\hline 10 & $4 \mathrm{E}-02$ & $1 \mathrm{E}-02$ & $8 \mathrm{E}-03$ & 7E-03 & $3 \mathrm{E}-03$ & $2 \mathrm{E}-03$ & $1 \mathrm{E}-03$ & $9 \mathrm{E}-04$ & $6 \mathrm{E}-04$ & $5 \mathrm{E}-04$ & $4 \mathrm{E}-04$ & $4 \mathrm{E}-04$ & $2 \mathrm{E}-04$ & 1E-04 & 7E-06 & $1 \mathrm{E}-06$ & 7E-02 \\
\hline 13 & $4 \mathrm{E}-02$ & $1 \mathrm{E}-02$ & $8 \mathrm{E}-03$ & 7E-03 & $3 \mathrm{E}-03$ & $1 \mathrm{E}-03$ & $1 \mathrm{E}-03$ & $8 \mathrm{E}-04$ & $6 \mathrm{E}-04$ & $5 \mathrm{E}-04$ & 4E-04 & 4E-04 & $2 \mathrm{E}-04$ & 9E-05 & 7E-06 & $9 \mathrm{E}-07$ & 7E-02 \\
\hline 17 & $4 \mathrm{E}-02$ & $1 \mathrm{E}-02$ & $8 \mathrm{E}-03$ & 7E-03 & $3 \mathrm{E}-03$ & $2 \mathrm{E}-03$ & $1 \mathrm{E}-03$ & $8 \mathrm{E}-04$ & $6 \mathrm{E}-04$ & $5 \mathrm{E}-04$ & $4 \mathrm{E}-04$ & $4 \mathrm{E}-04$ & $2 \mathrm{E}-04$ & $1 \mathrm{E}-04$ & 7E-06 & $1 \mathrm{E}-06$ & 7E-02 \\
\hline 22 & 3E-02 & $1 \mathrm{E}-02$ & $6 \mathrm{E}-03$ & $6 \mathrm{E}-03$ & $2 \mathrm{E}-03$ & $1 \mathrm{E}-03$ & 9E-04 & $6 \mathrm{E}-04$ & $5 \mathrm{E}-04$ & $4 \mathrm{E}-04$ & 3E-04 & 3E-04 & $1 \mathrm{E}-04$ & $8 \mathrm{E}-05$ & $5 \mathrm{E}-06$ & $8 \mathrm{E}-07$ & $6 \mathrm{E}-02$ \\
\hline 28 & $1 \mathrm{E}-02$ & $5 \mathrm{E}-03$ & 3E-03 & $3 \mathrm{E}-03$ & $1 \mathrm{E}-03$ & $6 \mathrm{E}-04$ & $4 \mathrm{E}-04$ & $3 \mathrm{E}-04$ & $2 \mathrm{E}-04$ & 2E-04 & $2 \mathrm{E}-04$ & $2 \mathrm{E}-04$ & $6 \mathrm{E}-05$ & $4 \mathrm{E}-05$ & $3 \mathrm{E}-06$ & $4 \mathrm{E}-07$ & $2 \mathrm{E}-02$ \\
\hline 36 & $2 \mathrm{E}-02$ & 6E-03 & $4 \mathrm{E}-03$ & $4 \mathrm{E}-03$ & $2 \mathrm{E}-03$ & 8E-04 & 6E-04 & $4 \mathrm{E}-04$ & $3 \mathrm{E}-04$ & $3 \mathrm{E}-04$ & $2 \mathrm{E}-04$ & $2 \mathrm{E}-04$ & $9 \mathrm{E}-05$ & $5 \mathrm{E}-05$ & $4 \mathrm{E}-06$ & $5 \mathrm{E}-07$ & $4 \mathrm{E}-02$ \\
\hline 46 & 7E-03 & $2 \mathrm{E}-03$ & $1 \mathrm{E}-03$ & $1 \mathrm{E}-03$ & $6 \mathrm{E}-04$ & 3E-04 & $2 \mathrm{E}-04$ & $1 \mathrm{E}-04$ & $1 \mathrm{E}-04$ & 9E-05 & $7 \mathrm{E}-05$ & $7 \mathrm{E}-05$ & $3 \mathrm{E}-05$ & $2 \mathrm{E}-05$ & $1 \mathrm{E}-06$ & $2 \mathrm{E}-07$ & $1 \mathrm{E}-02$ \\
\hline 60 & $5 \mathrm{E}-03$ & $1 \mathrm{E}-03$ & 9E-04 & $8 \mathrm{E}-04$ & $4 \mathrm{E}-04$ & $2 \mathrm{E}-04$ & $1 \mathrm{E}-04$ & $1 \mathrm{E}-04$ & 7E-05 & 6E-05 & $5 \mathrm{E}-05$ & $5 \mathrm{E}-05$ & $2 \mathrm{E}-05$ & 1E-05 & $8 \mathrm{E}-07$ & $1 \mathrm{E}-07$ & $9 \mathrm{E}-03$ \\
\hline 77 & $4 \mathrm{E}-03$ & $1 \mathrm{E}-03$ & $9 \mathrm{E}-04$ & $8 \mathrm{E}-04$ & $3 \mathrm{E}-04$ & $2 \mathrm{E}-04$ & $1 \mathrm{E}-04$ & $9 \mathrm{E}-05$ & 7E-05 & $6 \mathrm{E}-05$ & $5 \mathrm{E}-05$ & $4 \mathrm{E}-05$ & $2 \mathrm{E}-05$ & $1 \mathrm{E}-05$ & $8 \mathrm{E}-07$ & $1 \mathrm{E}-07$ & $8 \mathrm{E}-03$ \\
\hline 100 & 3E-03 & $9 \mathrm{E}-04$ & $5 \mathrm{E}-04$ & $5 \mathrm{E}-04$ & $2 \mathrm{E}-04$ & $1 \mathrm{E}-04$ & $8 \mathrm{E}-05$ & $6 \mathrm{E}-05$ & $4 \mathrm{E}-05$ & $4 \mathrm{E}-05$ & $3 \mathrm{E}-05$ & 3E-05 & $1 \mathrm{E}-05$ & 7E-06 & $5 \mathrm{E}-07$ & 7E-08 & $5 \mathrm{E}-03$ \\
\hline 129 & $2 \mathrm{E}-03$ & $6 \mathrm{E}-04$ & $4 \mathrm{E}-04$ & $3 \mathrm{E}-04$ & $1 \mathrm{E}-04$ & $7 \mathrm{E}-05$ & $5 \mathrm{E}-05$ & $4 \mathrm{E}-05$ & $3 \mathrm{E}-05$ & $2 \mathrm{E}-05$ & $2 \mathrm{E}-05$ & $2 \mathrm{E}-05$ & $8 \mathrm{E}-06$ & $4 \mathrm{E}-06$ & $3 \mathrm{E}-07$ & $4 \mathrm{E}-08$ & $4 \mathrm{E}-03$ \\
\hline 167 & 7E-03 & $2 \mathrm{E}-03$ & $1 \mathrm{E}-03$ & $1 \mathrm{E}-03$ & $5 \mathrm{E}-04$ & 3E-04 & $2 \mathrm{E}-04$ & $1 \mathrm{E}-04$ & $1 \mathrm{E}-04$ & 9E-05 & 7E-05 & 7E-05 & $3 \mathrm{E}-05$ & 2E-05 & 1E-06 & $2 \mathrm{E}-07$ & $1 \mathrm{E}-02$ \\
\hline 215 & $4 \mathrm{E}-03$ & $1 \mathrm{E}-03$ & 7E-04 & 7E-04 & $3 \mathrm{E}-04$ & $1 \mathrm{E}-04$ & $1 \mathrm{E}-04$ & $8 \mathrm{E}-05$ & $6 \mathrm{E}-05$ & $5 \mathrm{E}-05$ & $4 \mathrm{E}-05$ & $4 \mathrm{E}-05$ & $2 \mathrm{E}-05$ & $9 \mathrm{E}-06$ & 7E-07 & $9 \mathrm{E}-08$ & 7E-03 \\
\hline 278 & $2 \mathrm{E}-03$ & 7E-04 & $4 \mathrm{E}-04$ & $4 \mathrm{E}-04$ & $2 \mathrm{E}-04$ & $8 \mathrm{E}-05$ & 6E-05 & $4 \mathrm{E}-05$ & $3 \mathrm{E}-05$ & $3 \mathrm{E}-05$ & $2 \mathrm{E}-05$ & $2 \mathrm{E}-05$ & $9 \mathrm{E}-06$ & $5 \mathrm{E}-06$ & $4 \mathrm{E}-07$ & $5 \mathrm{E}-08$ & $4 \mathrm{E}-03$ \\
\hline 359 & $3 \mathrm{E}-03$ & $1 \mathrm{E}-03$ & $6 \mathrm{E}-04$ & $5 \mathrm{E}-04$ & $2 \mathrm{E}-04$ & $1 \mathrm{E}-04$ & $9 \mathrm{E}-05$ & $6 \mathrm{E}-05$ & $5 \mathrm{E}-05$ & $4 \mathrm{E}-05$ & $3 \mathrm{E}-05$ & $3 \mathrm{E}-05$ & $1 \mathrm{E}-05$ & 7E-06 & $5 \mathrm{E}-07$ & $8 \mathrm{E}-08$ & $6 \mathrm{E}-03$ \\
\hline 464 & 6E-04 & 2E-04 & $1 \mathrm{E}-04$ & $1 \mathrm{E}-04$ & $5 \mathrm{E}-05$ & $2 \mathrm{E}-05$ & $2 \mathrm{E}-05$ & $1 \mathrm{E}-05$ & $1 \mathrm{E}-05$ & 9E-06 & 7E-06 & 7E-06 & 3E-06 & 2E-06 & 1E-07 & $2 \mathrm{E}-08$ & $1 \mathrm{E}-03$ \\
\hline 599 & $4 \mathrm{E}-04$ & 1E-04 & $8 \mathrm{E}-05$ & 7E-05 & $3 \mathrm{E}-05$ & $1 \mathrm{E}-05$ & $1 \mathrm{E}-05$ & $8 \mathrm{E}-06$ & $6 \mathrm{E}-06$ & $5 \mathrm{E}-06$ & $4 \mathrm{E}-06$ & $4 \mathrm{E}-06$ & $2 \mathrm{E}-06$ & $1 \mathrm{E}-06$ & 7E-08 & $1 \mathrm{E}-08$ & 7E-04 \\
\hline 774 & 4E-04 & 1E-04 & $9 \mathrm{E}-05$ & $8 \mathrm{E}-05$ & 3E-05 & $2 \mathrm{E}-05$ & $1 \mathrm{E}-05$ & $9 \mathrm{E}-06$ & 7E-06 & $6 \mathrm{E}-06$ & $4 \mathrm{E}-06$ & $4 \mathrm{E}-06$ & $2 \mathrm{E}-06$ & $1 \mathrm{E}-06$ & $8 \mathrm{E}-08$ & $1 \mathrm{E}-08$ & $8 \mathrm{E}-04$ \\
\hline 1000 & $3 \mathrm{E}-05$ & 9E-06 & $6 \mathrm{E}-06$ & $5 \mathrm{E}-06$ & $2 \mathrm{E}-06$ & $1 \mathrm{E}-06$ & $8 \mathrm{E}-07$ & $6 \mathrm{E}-07$ & $4 \mathrm{E}-07$ & $4 \mathrm{E}-07$ & $3 \mathrm{E}-07$ & $3 \mathrm{E}-07$ & $1 \mathrm{E}-07$ & 7E-08 & 5E-09 & 7E-10 & $6 \mathrm{E}-05$ \\
\hline Total & & & & & & & & & & & & & & & & & \\
\hline $\begin{array}{l}\text { Volume } \\
\text { Fraction }\end{array}$ & 0.515 & 0.166 & 0.106 & 0.095 & 0.041 & 0.02 & 0.016 & 0.011 & 0.0081 & 0.0069 & 0.0055 & 0.0054 & 0.0023 & 0.0013 & 0.000094 & 0.000013 & 1.0 \\
\hline
\end{tabular}




\subsubsection{Rheology}

Rheology data are available for a limited number of sludge tanks. Bingham model parameters for slurries and sediment shear strength are considered.

The Bingham rheological model data, consistency (viscosity) and yield stress, provided in Poloski et al. (2008) for slurries from 18 sludge tanks are presented in Figure 2.5 and Figure 2.6 as functions of the approximated UDS volume and mass fractions, respectively. The samples are typically sludge sediment diluted to various concentrations with supernatant liquid from the same sludge tank. All measurements are taken ex-tank, and the measurement temperature range is 25 to $95^{\circ} \mathrm{C}$.

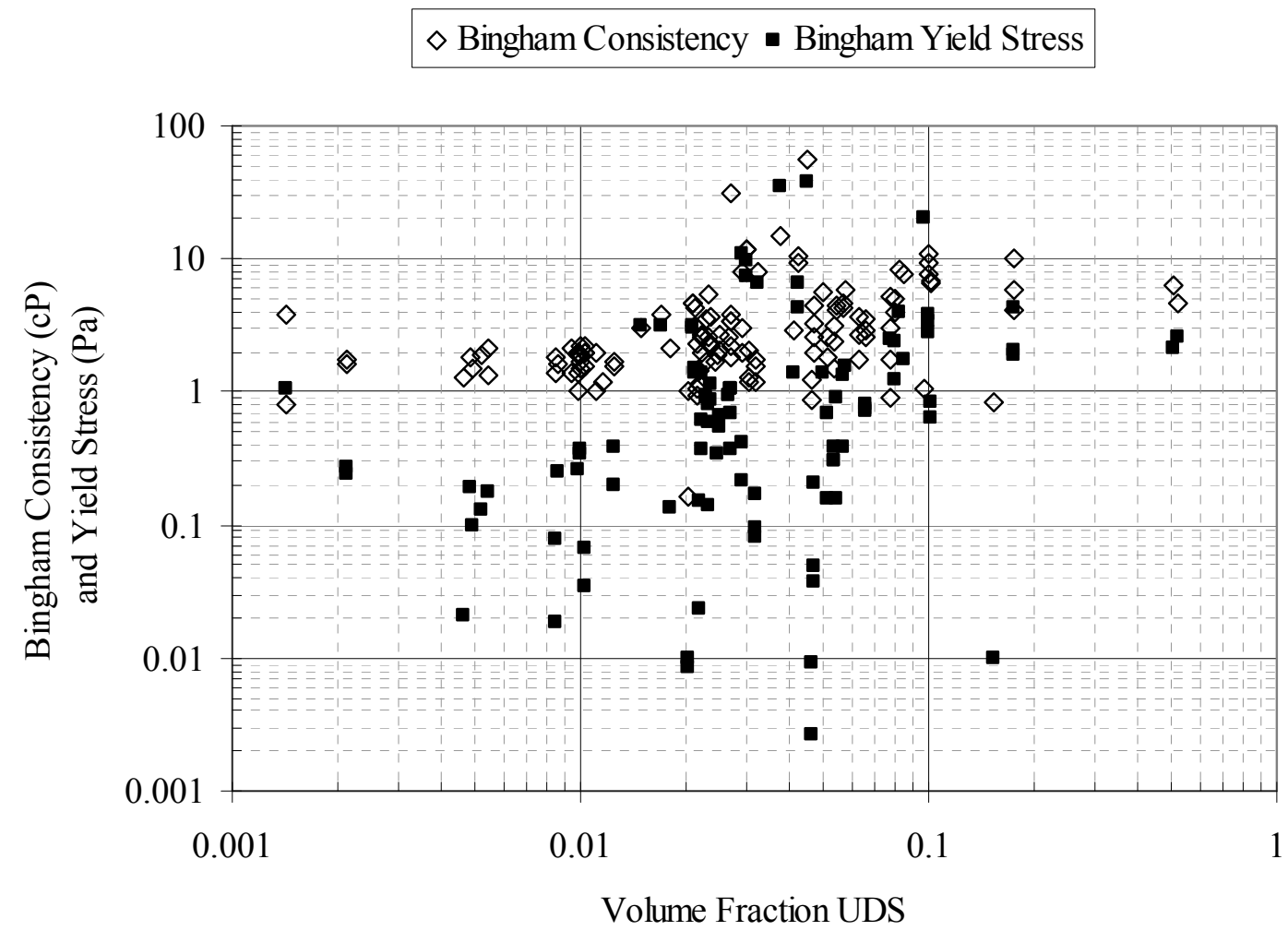

Figure 2.5. Bingham Rheological Model Data for Slurries from 18 Hanford Sludge Tanks, Volume Fraction UDS. Data from Poloski et al. (2007). 


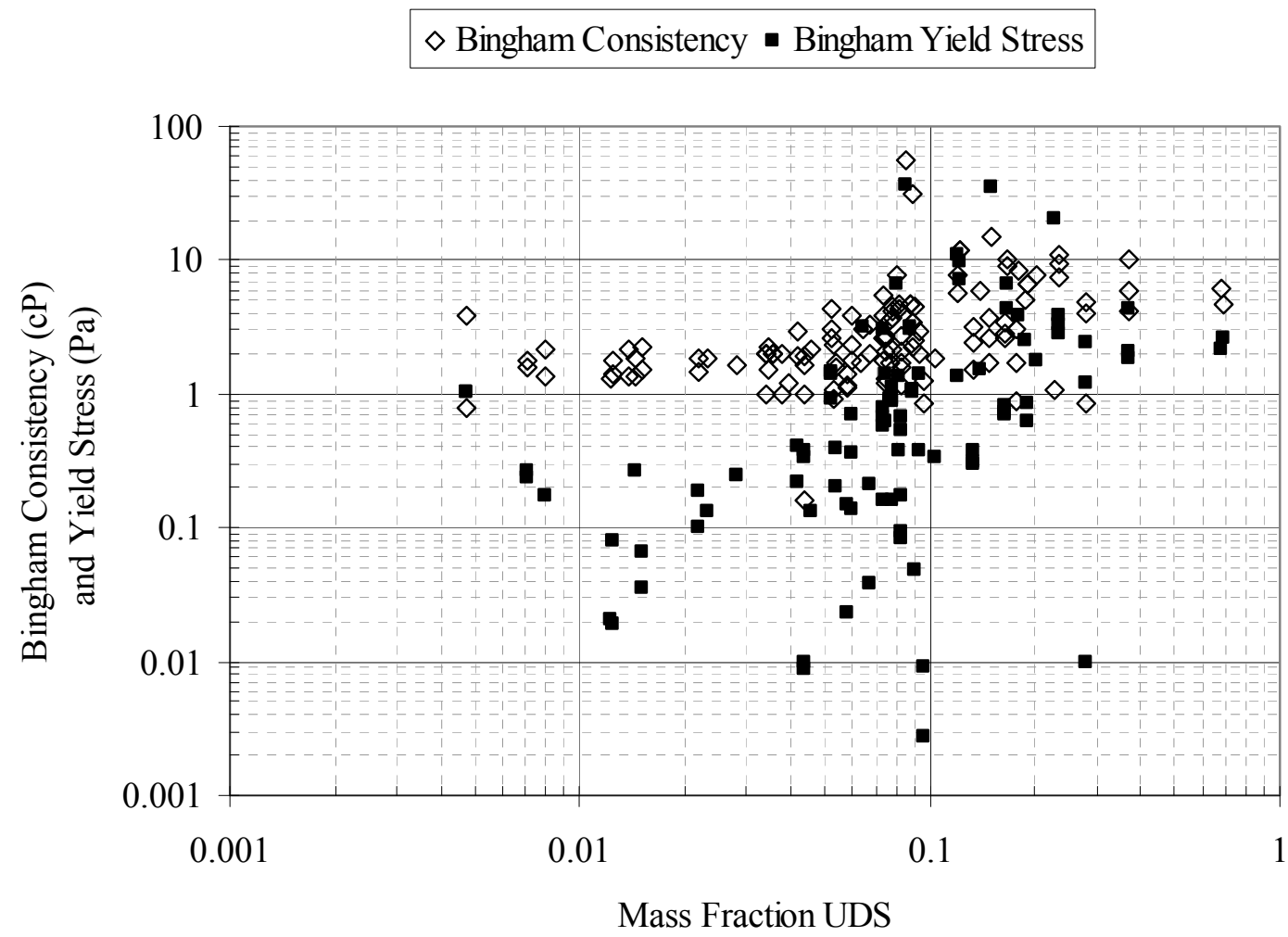

Figure 2.6. Bingham Rheological Model Data for Slurries from 18 Hanford Sludge Tanks, Mass Fraction UDS. Data from Poloski et al. (2007).

A 95\% empirical limit for the Bingham rheological model data of Figure 2.6 is provided for the consistency and yield stress in Figure 2.7 and Figure 2.8. Partitions in the UDS mass fraction are taken, and the $2.5 \%, 50 \%$ (median), and $97.5 \%$ probabilities of the partitions are determined. The resultant 95\% empirical limit and median are represented in Figure 2.7 and Figure 2.8 at the average mass fraction UDS of the partitions. The lack of clear functionality of the Bingham model parameters with the UDS concentration may be expected because of the varied waste and sample conditions represented. The general expected trend (see references listed in Section 1) of increased rheology with increased UDS concentration is observable for the medians. 


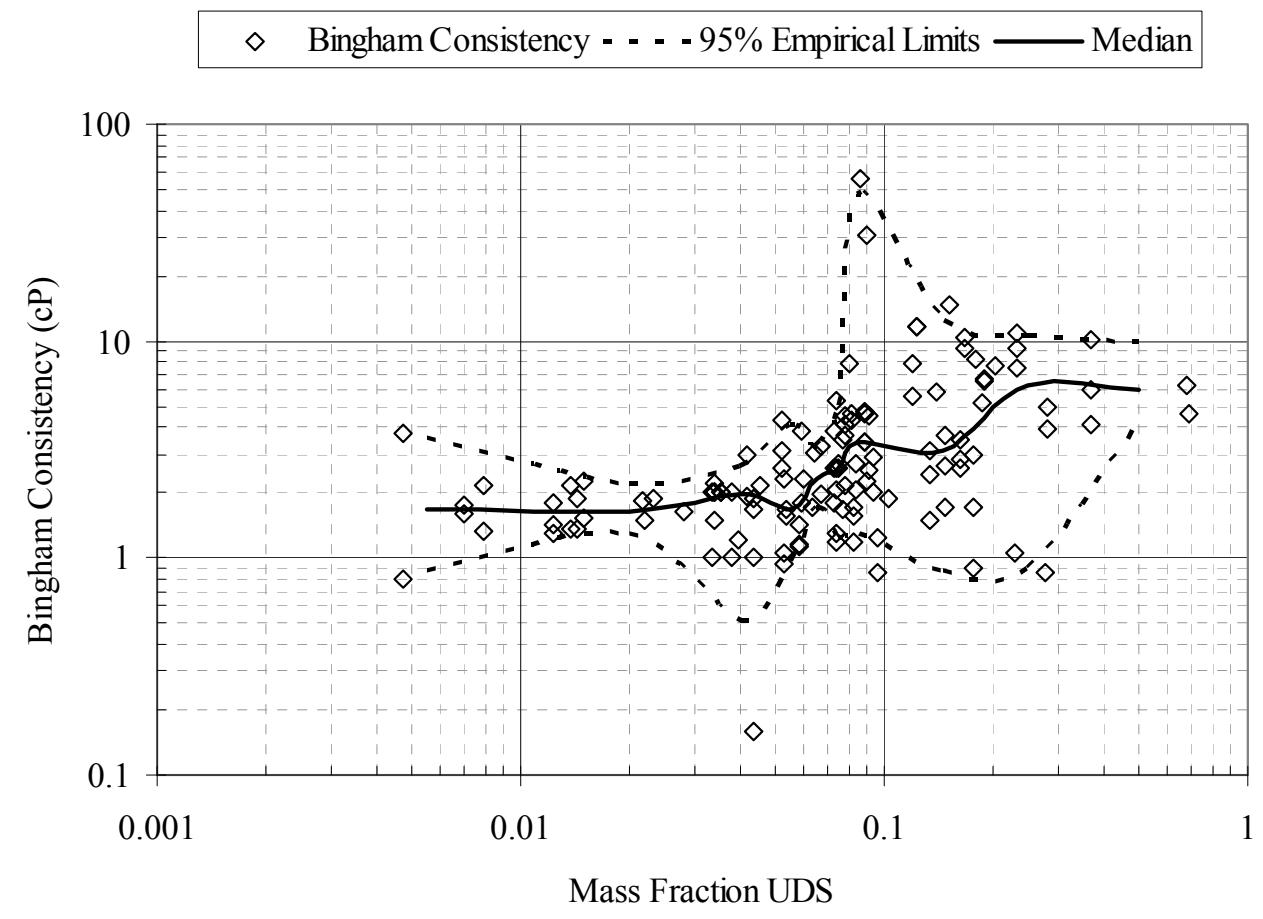

Figure 2.7. Probabilities for Bingham Consistency for Slurries from 18 Hanford Sludge Tanks, Mass Fraction UDS. Data from Poloski et al. (2007).

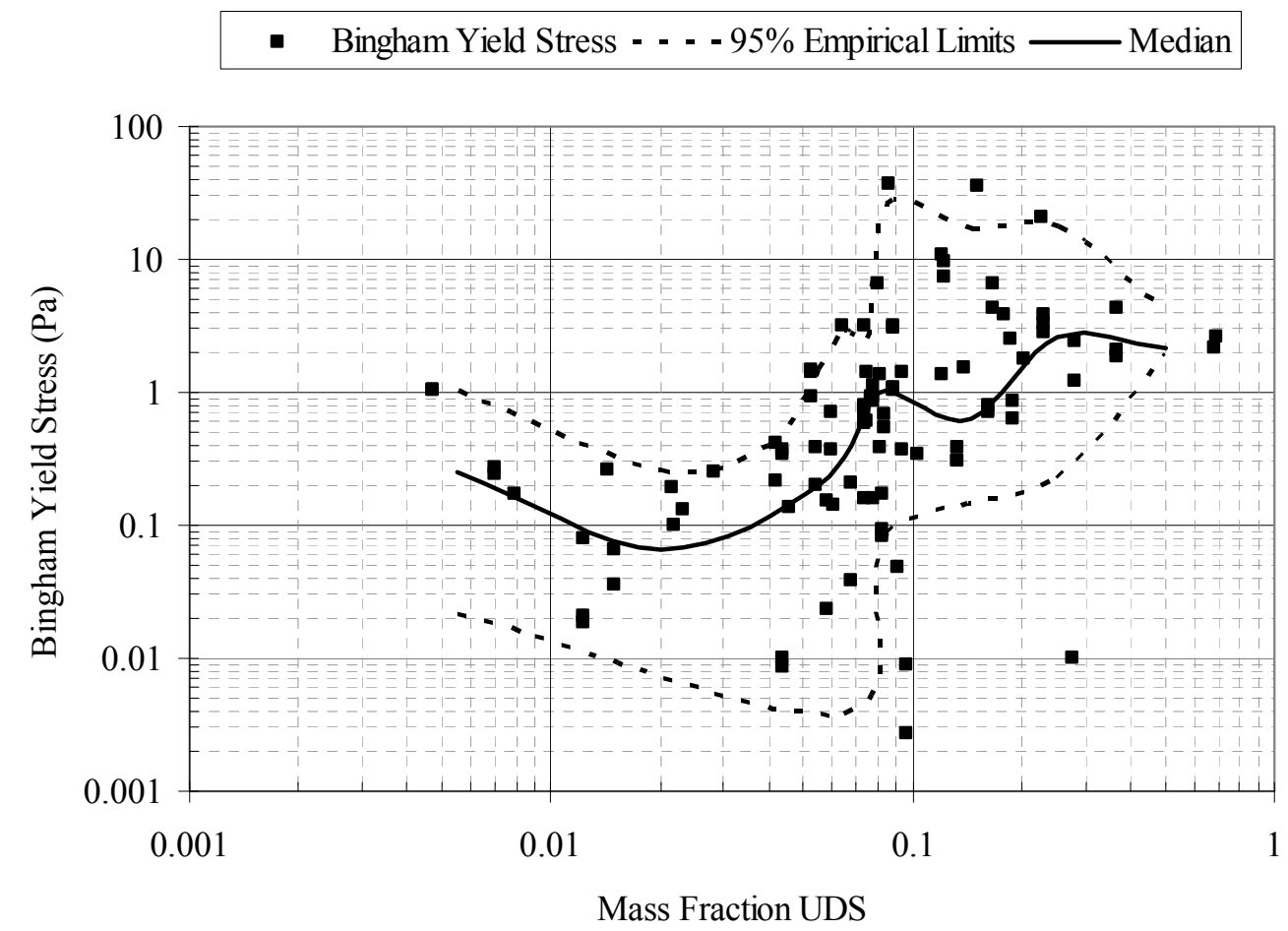

Figure 2.8. Probabilities for Bingham Yield Stress for Slurries from 18 Hanford Sludge Tanks, Mass Fraction UDS. Data from Poloski et al. (2007). 
The sediment shear strength data provided in Gauglitz et al. (2009) for 15 sludge tanks are presented in Figure 2.9 and Figure 2.10 as functions of the approximated UDS volume and mass fractions, respectively. The data presented are from the shear vane technique on ex-tank waste sludge sediment samples.

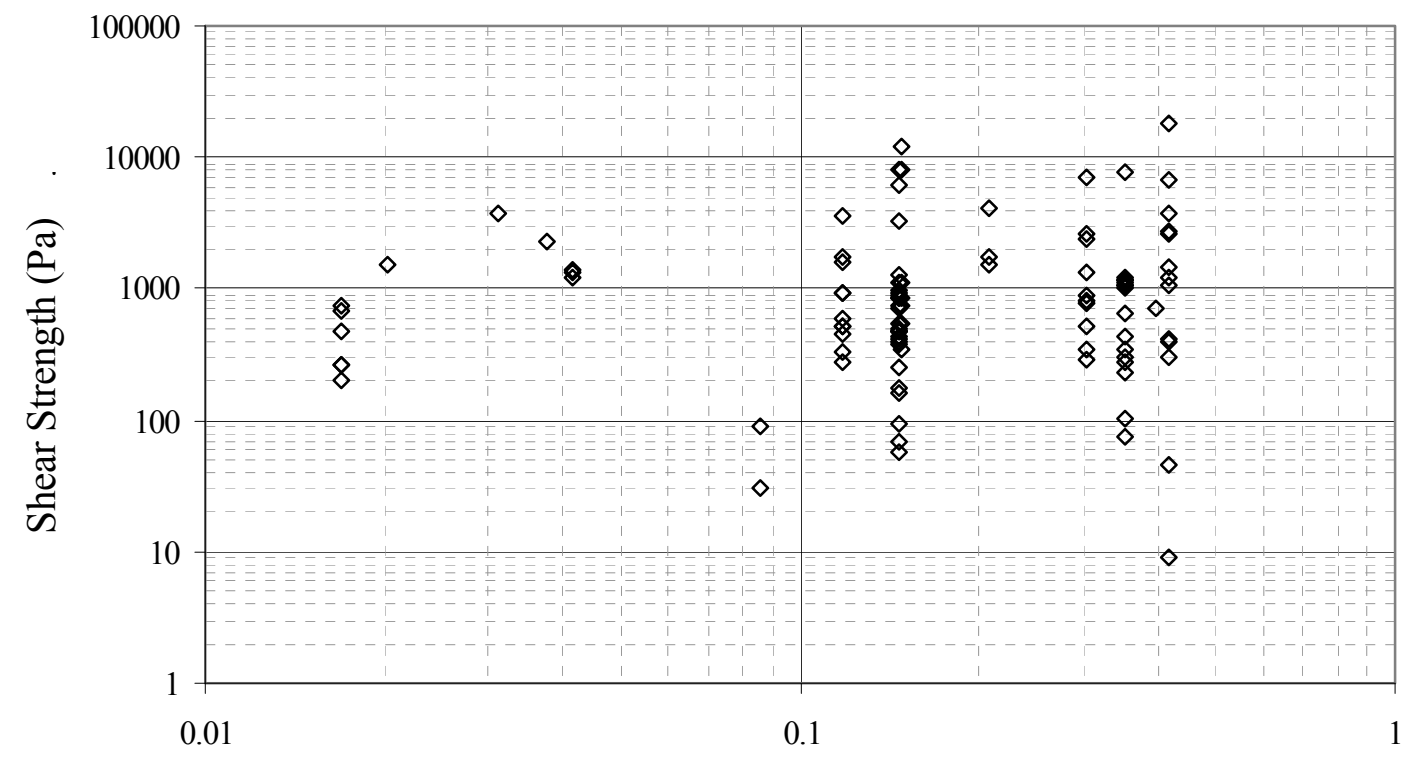

Volume Fraction UDS

Figure 2.9. Sediment Shear Strength Data for 16 Hanford Sludge Tanks, Volume Fraction UDS. Data from Gauglitz et al. (2009).

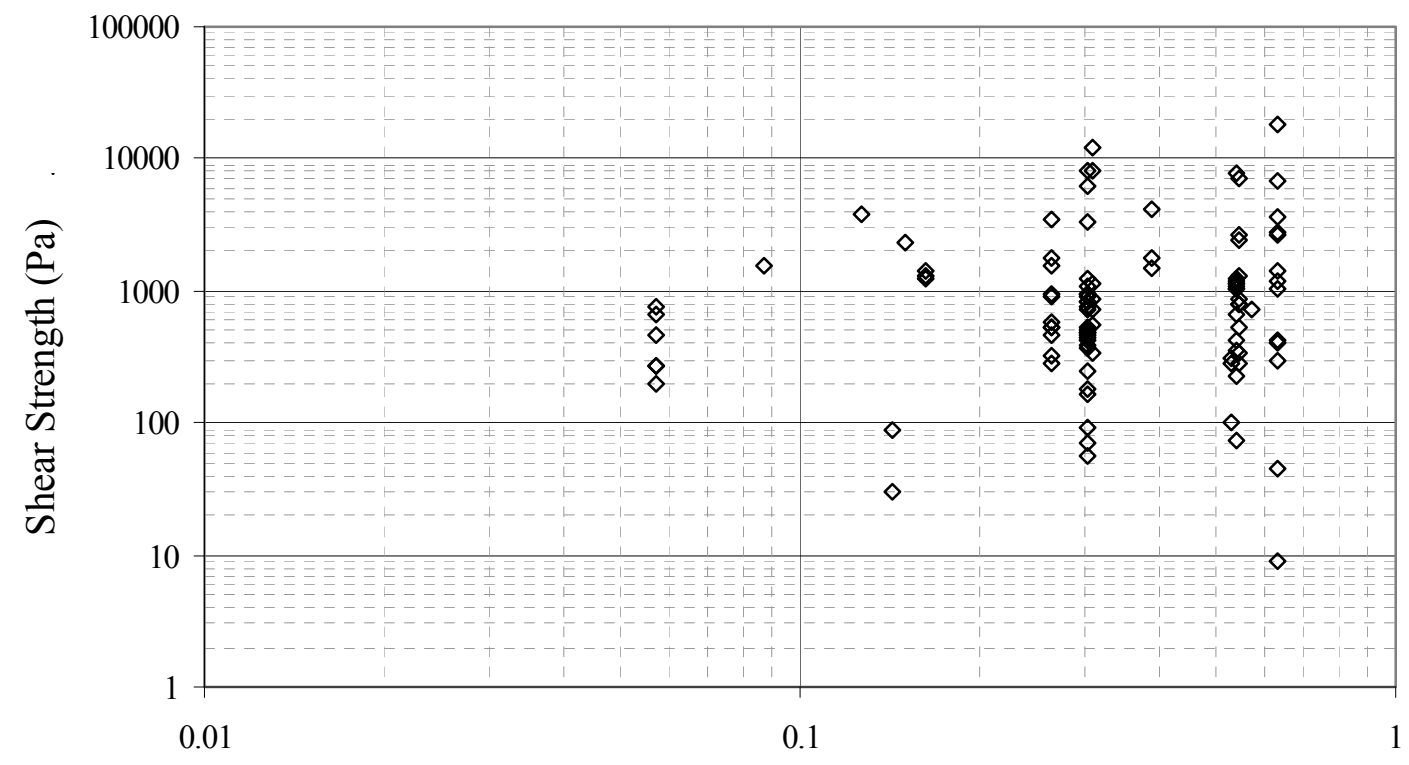

Mass Fraction UDS

Figure 2.10. Sediment Shear Strength Data for 15 Hanford Sludge Tanks, Mass Fraction UDS. Data from Gauglitz et al. (2009). 
As with the Bingham rheological model data above, the 95\% empirical limit and median for the data of Figure 2.10 are provided in Figure 2.11. A shear strength functionality with the UDS concentration (see Section 1) may be expected to be confounded by the varied waste and sample conditions represented. The median shear strength is shown to be nominally constant with UDS concentration.

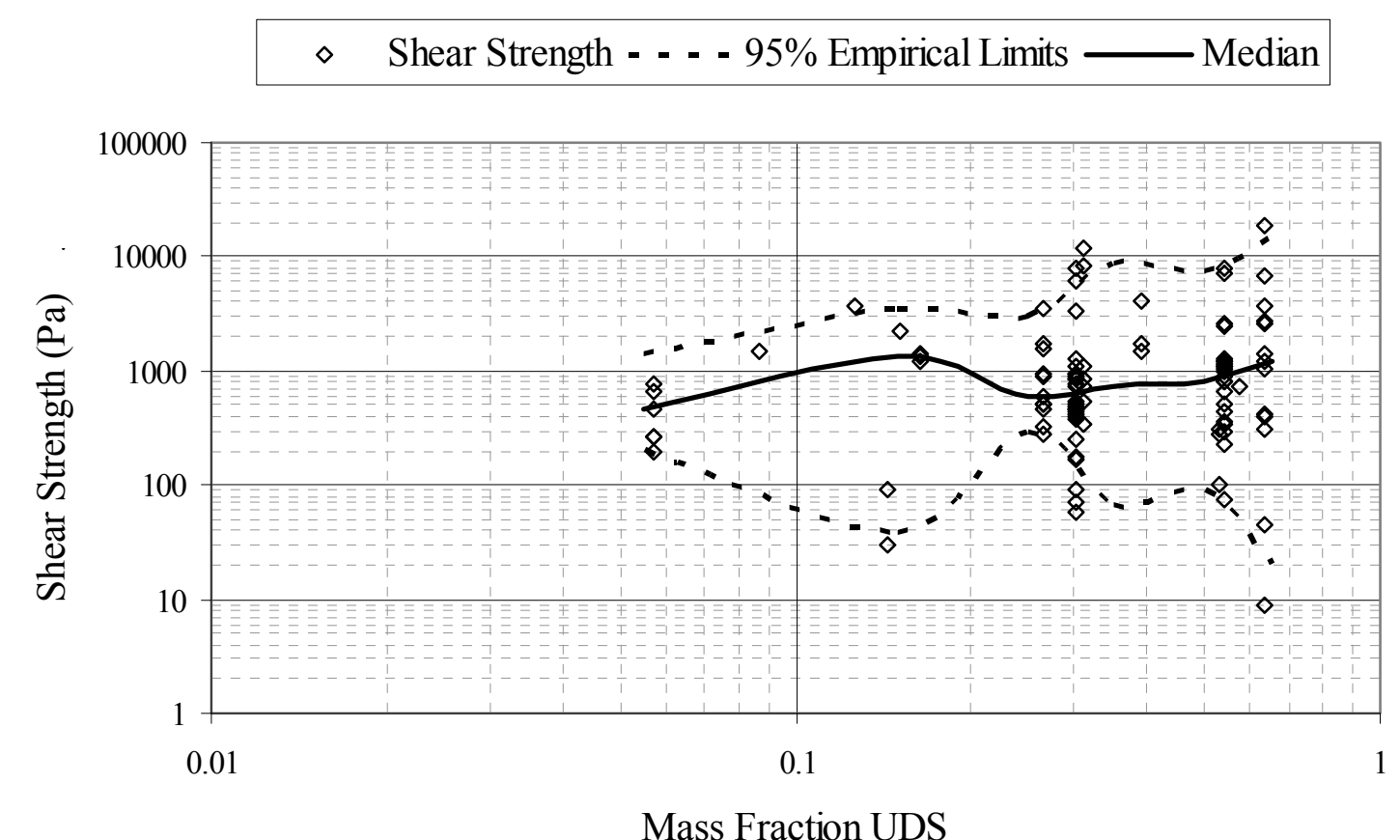

Figure 2.11. Probabilities for Sediment Shear Strength Data for 15 Hanford Sludge Tanks, Mass Fraction UDS. Data from Gauglitz et al. (2009).

\subsubsection{Hanford Sludge Waste Physical Property Summary}

The Hanford sludge waste properties presented above for the liquid, UDS, slurry, and sediment are summarized in Table 2.2. Data sources are presented/referenced in the preceding sections. Parameter values are median values unless otherwise noted.

Table 2.2. Hanford Sludge Waste Properties Summary

\begin{tabular}{l|ll}
\hline & Property & Value (units) or Reference \\
\hline Liquid & Density & $1.1(\mathrm{~g} / \mathrm{mL})$ \\
& Viscosity at Median Density & $<2.5(\mathrm{cP})$ \\
& $\mathrm{pH}$ & 13.2 \\
\hline Undissolved Solids & PSDD & Table 2.1 \\
\hline Slurry & Bingham Consistency & Figure 2.7 \\
& Bingham Yield Stress & Figure 2.8 \\
\cline { 3 - 3 } Sediment & Mass Fraction UDS & 0.53 \\
& Shear Strength & Figure 2.11 \\
\hline
\end{tabular}




\subsection{Simulant 1 Selection}

Simulants previously produced by Pacific Northwest National Laboratory (PNNL) with a level of complete characterization (some simulants were intended only as chemical simulants; therefore, rheology was not measured, etc.) include pretreated waste simulants AZ-101 (Stewart et al. 2007), AZ-101 (Golcar et al. 2000), AY-102 (Zamecnik et al. 2004), AZ-102 (Hansen et al. 2001), and the WTP crossflow ultrafiltration blended matrix simulant three (CBM-3) (Russell et al. 2009a).

The UDS portion of the AZ-101 of Stewart et al. (2007), AY-102, and AZ-102 referenced simulants was produced primarily by hydroxide precipitation (see Section 3). The hydroxide precipitation methodology is representative of the processes of UDS and supernate formation in the HLW tanks. The UDS of the AZ-101 simulant of Golcar et al. (2000) was provided via dry-powder solid-phase compounds, and the CBM-3 simulant was produced using a combination of the approaches. The CBM-3 simulant differs from the Pretreatment Engineering Platform (PEP) simulant (Kurath et al. 2009, Scheele et al. 2009) solely in minor trace metals of the precipitated hydroxide portion of the simulant.

Subsequently, some of the reported characterizations for CBM-3 are taken from characterizations of the PEP simulant.

CBM-3 is selected as Simulant 1 because of its level of characterization and favorable comparison to Hanford sludge. A tabular comparison of the properties of the listed simulants to those of Hanford sludge is provided in Table 2.3. The AZ-102 simulant is discarded from further consideration as its characterization is incomplete relative to the other simulants. The AY-102 simulant also has a reduced level of characterization and is not considered further as those characterizations made are not substantively more comparative to Hanford sludge than those of the remaining three simulants. The AZ101 simulant of Golcar et al. (2000) has its UDS fraction, as specified above, composed entirely of drypowder solid-phase compounds. The UDS is composed primarily of an iron compound, while the Hanford sludge as a whole is predominantly aluminum. Further, its liquid phase is water, so the supernate density, viscosity, and $\mathrm{pH}$ are dissimilar to Hanford waste, and this simulant is thus not considered further.

The two remaining simulants for consideration include the precipitated hydroxide AZ-101 simulant (Stewart et al. 2007) and the CBM-3 simulant, which uses a combination of precipitated hydroxide and solid-phase compound powders. The liquid phase and predominant UDS phase compound of the Stewart et al. AZ-101 simulant are similar to the Golcar et al. AZ-101 simulant and do not represent the aggregate Hanford sludge as well as CBM-3. 
Table 2.3. Simulant and Hanford Sludge Waste Properties Comparison

\begin{tabular}{|c|c|c|c|c|c|c|c|}
\hline \multicolumn{2}{|c|}{ Property } & Hanford Sludge $^{(\mathrm{a})}$ & AZ-101 ${ }^{(\mathrm{b})}$ & AZ-101 ${ }^{(\mathrm{c})}$ & AY-102 $2^{(d)}$ & AZ-102 $2^{(\mathrm{e})}$ & $\mathrm{CBM}^{3} 3^{(\mathrm{f})}$ \\
\hline \multicolumn{2}{|c|}{$\begin{array}{l}\text { Liquid Density } \\
(\mathrm{g} / \mathrm{mL})\end{array}$} & $1.1-1.2$ & 1.03 & 1.0 & 1.16 & - & 1.23 \\
\hline \multicolumn{2}{|c|}{$\begin{array}{c}\text { Liquid } \\
\text { Viscosity (cP) }\end{array}$} & $\sim 2$ & $-(\mathrm{g})$ & 1 & 2.4 & - & 2.7 \\
\hline \multicolumn{2}{|c|}{$\mathrm{pH}$} & 13.2 & 12 & $\sim 7$ & 13.4 & - & $>14^{(\mathrm{i})}$ \\
\hline \multicolumn{2}{|c|}{$\begin{array}{l}\text { Solid Phase } \\
\text { Compound, } \\
\text { Mass Fraction }\end{array}$} & $\begin{array}{l}\mathbf{A l}(\mathbf{O H})_{3}, 0.449 \\
(\mathbf{N a A l S i O})_{4} \cdot\left(\mathrm{NaNO}_{3}\right)_{1.6} \cdot 2 \mathbf{H}_{2} \mathbf{O} \text {, } \\
0.142 \\
\text { AlOOH, } 0.115 \\
\mathrm{NaAlCO}_{3}(\mathbf{O H})_{2}, 0.083 \\
\mathbf{F e}_{2} \mathbf{O}_{3}, 0.078 \\
\quad \text { see Table } 2.1\end{array}$ & $\begin{array}{l}\mathbf{F e O O H}, 0.46 \\
\mathrm{ZrO}_{2}, 0.125 \\
\mathrm{Al}_{2} \mathbf{O}_{3}, 0.15\end{array}$ & $\begin{array}{l}\mathrm{Fe}_{2} \mathbf{O}_{3}, 0.58 \\
\mathbf{A l}(\mathbf{O H})_{3}, 0.16 \\
\mathbf{Z r}(\mathbf{O H})_{4}, 0.13 \\
\text { AlOOH, } 0.08\end{array}$ & $-^{(h)}$ & - & $\begin{array}{l}\mathrm{Al}(\mathbf{O H})_{3}, 0.355 \\
\mathrm{AlOOH}, 0.355 \\
\mathrm{Fe}(\mathbf{O H})_{3}, 0.14 \\
\mathrm{Na}_{2} \mathrm{C}_{2} \mathbf{O}_{4}, 0.103\end{array}$ \\
\hline \multirow{5}{*}{$\begin{array}{c}\text { PSD } \\
\text { Percentile } \\
(\mu \mathrm{m})\end{array}$} & 1 & 0.65 & - & - & 1 & 1 & 0.94 \\
\hline & 5 & 1 & 0.35 & .25 & 1.4 & 3 & 1.6 \\
\hline & 50 & 6.3 & 3.6 & $\sim 10$ & 5 & 14 & 9.5 \\
\hline & 95 & 59 & 72 & $\sim 30$ & 33 & 55 & 36 \\
\hline & 99 & 256 & - & - & 62 & 88 & 59 \\
\hline \multicolumn{2}{|c|}{$\begin{array}{l}\text { UDS Crystal } \\
\text { Density } \\
(\mathrm{g} / \mathrm{mL}) \\
\end{array}$} & $\begin{array}{l}2.42-11.43 \\
\text { see Table } 2.1\end{array}$ & $4-5.9$ & $2.42-5$ & - & - & $2.3-5.9$ \\
\hline \multicolumn{2}{|c|}{$\begin{array}{l}(\sim 25 \mathrm{C}): \\
\text { UDS mass } \\
\text { fraction, yield } \\
\text { stress }(\mathrm{Pa}) \text {, } \\
\text { consistency } \\
(\mathrm{cP})\end{array}$} & $\begin{array}{l}\text { see Figure } 2.7 \text { and } \\
\quad \text { Figure } 2.8\end{array}$ & $\begin{array}{c}0.26^{10}, 32,32 \\
0.23^{10}, 14,14 \\
0.18^{10}, 4,4\end{array}$ & $\begin{array}{c}0.1,0.6,4 \\
0.3,2,9 \\
0.4,5,21\end{array}$ & $0.07,1.2,7$ & $\begin{array}{c}0.1,1.9,3.6 \\
0.15,9.6,6 \\
0.2,41,21.5\end{array}$ & $\begin{array}{c}0.06,0,4.7 \\
0.31,30,26^{(\mathrm{i})} \\
0.40,20,80^{(\mathrm{i})}\end{array}$ \\
\hline \multicolumn{2}{|c|}{$\begin{array}{c}\text { Strength: } \\
\text { UDS mass } \\
\text { fraction, shear } \\
\text { strength }(\mathrm{Pa}) \\
\end{array}$} & see Figure 2.11 & $\begin{array}{c}0.26,{ }^{(\mathrm{j})} 33 \\
0.23,{ }^{\mathrm{j})} 14 \\
0.18,{ }^{(\mathrm{j})} 7\end{array}$ & - & $0.07,6.7$ & - & $\begin{array}{c}0.32,34^{(\mathrm{i})} \\
0.40,1383^{(\mathrm{i})}\end{array}$ \\
\hline \\
\hline \multicolumn{8}{|c|}{$\begin{array}{l}\text { (b) Stewart et al. (2007) and project record documentation 071112_AZ_I } \\
\text { Group LLC MSDS for Simulant AZ-101 HLW, Poloski et al. (2009) }\end{array}$} \\
\hline \multicolumn{8}{|c|}{ (c) Golcar et al. (2000), Bontha et al. (2003), Meyer et al. (2009) } \\
\hline \multicolumn{8}{|c|}{ (d) Zamecnik et al. (2004) } \\
\hline \multicolumn{8}{|c|}{ (e) Hansen et al. (2001) } \\
\hline \multicolumn{8}{|c|}{ (f) Russell et al. (2009a), Russell et al. (2009b), Kurath et al. (2009), Geeting et al. (2009) } \\
\hline \multicolumn{8}{|c|}{ (g) -, no data available. } \\
\hline \multirow{2}{*}{\multicolumn{8}{|c|}{$\begin{array}{l}\text { (h) Zamecnik et al. (2004) states “..supernate and solids [analyte] co } \\
\text { well...UDS 50\% of [waste]"; Wells and Ressler (2009) provide } A \\
\text { (i) Measurement performed for current work, see Section } 4 .\end{array}$}} \\
\hline & ureme & ent performed for current $\mathrm{w}$ & ork, see Sectio & on 4. & & & \\
\hline (j) Total & & s concentration; includes Ul & DS and dissolv & ved solids. & & & \\
\hline
\end{tabular}


An interesting distinction of the precipitated hydroxide simulants and those using solid-phase compound powders is their gravity-settling behavior. For actual Hanford waste, laboratory experiments (summary provided in Poloski et al. 2007) and in situ data (Gauglitz et al. 2009) indicate rapid UDS settling. The rapid Hanford UDS gravity settling rate is more closely represented by those simulants with the entire or portion of the UDS component from dry-powder solid-phase compounds. The AZ-101 simulant of Golcar et al. (2000) was observed to settle from a well-mixed condition to a settled solids layer of approximately $30 \%$ by volume in less than approximately 4 to 5 days. (a) Laboratory settling of the CBM-3 simulant from a well-mixed condition to a settled solids layer of approximately $30 \%$ by volume in less than 10 hours is documented in Russell et al. (2009b).

Conversely, those simulants in which the UDS component was produced primarily by hydroxide precipitation are essentially non-settling. Following mixing and a nominally 3 -day shut-down period, the AZ-101 simulant of Stewart et al. (2007) at nominally $18 \mathrm{wt} \%$ total solids was observed to have approximately $1 \%$ clear liquid by volume. At higher solid concentrations, settling was reduced. ${ }^{(b)}$

It is important to note that there are differences in laboratory and in situ settling data for actual Hanford waste. Per Gauglitz et al. (2009), the laboratory settling data evaluated by Poloski et al. (2007) suggest that in situ settling in the Hanford tanks would require about 50 times as long to settle as the laboratory tests. In fact, both the laboratory and in situ data show, summarized approximately here, the volume percent of slurry in a vessel (i.e., the portion of the vessel with a UDS fraction) as opposed to UDS-free liquid, from a well-mixed initial state at $100 \%$, reduces to approximately $30 \%$ in less than 24 hours. Gauglitz et al. (2009) noted this inconsistency by stating:

"Scaling behavior, including the role of vessel size, of the settling dynamics and the buildup of strength in the settled layer, with a particular emphasis on shorter settling times and strength increase with depth into a layer is not well quantified with existing data and analysis. The best current estimates are presented in this report, but these estimates have uncertainty. Accurate predictions of the settling behavior and strength formation are needed, so the mixing system is designed to prevent settled layers that will exceed remobilization capabilities. Tank-farm studies of full-scale settling have shown substantially faster settling than expected based on laboratory tests. This inconsistency needs to be understood."

The settling behavior of the CBM-3 simulant is more representative of the actual waste behavior than the AZ-101 (Stewart et al. 2007) simulant. The liquid phase parameters, PSD, UDS parameters, and rheology of the CBM-3 simulant reasonably represent Hanford sludge (as defined in Section 2.1) in comparison to the other simulants listed in Table 2.3. Thus, the CBM-3 simulant is selected as Simulant 1. Specific comparison of the Simulant 1 parameters to the Hanford sludge is made in Section 4.

(a) Behavior noted in laboratory record book for Bontha et al. (2000). Following mixing, the test (nominally 10 -foot simulant depth in a 12.75 -foot-diameter vessel, approximately $18 \mathrm{wt} \%$ total solids loading) was left in a shut-down condition and unattended for approximately 4 to 5 days. The settled condition was observed at the end of this time period.

(b) Behavior noted in laboratory record book for Stewart et al. (2007). Simulant depth approximately 52 inches; test vessel 70-inch diameter. 


\subsection{Simulant 2 Selection: Sludge-of-Interest Chemistry}

As of 2009, it is planned to retrieve wastes from Tanks 241-C-104, C-111, and C-112 and relocate them into Tank AN-101. The sludge of interest, from the point of view of gas retention, is therefore a mixture of the four wastes. The constitutive properties of the mixture, and hence the potential for gas retention and release, cannot be predicted a priori. For this reason, characterization tests are to be performed on Simulant 2, which is a chemical simulant of the four-tank waste mixture.

The following procedure was used to develop the four-tank simulant chemical composition:

1) Obtain the average composition of the waste in each of the four tanks from predictions made by the Environmental Simulation Program (ESP) ${ }^{(a)}$ chemical thermodynamic model. The predictions were based on Best Basis Inventory (BBI) data. These predicted compositions are expressed in terms of compounds, not analytes, and provide distinct solid-phase and liquid-phase compositions.

2) Add the four inventories together, using the model-predicted volume fractions of liquid and dry solid, compositions of solid and liquid, and densities of solid and liquid, and the BBI estimates of total volume.

3) Assume that when the four tanks' wastes are mixed, there is no reaction leading to precipitation or dissolution so that the liquid- and solid-phase compositions are preserved.

4) Calculate the concentrations of significant analytes in the bulk mixture and use these as the basis for the recipe. The simulant is produced by adding hydroxide to a mixture of metal nitrates to precipitate hydroxides and oxyhydroxides and then adding a slurry of the sodium salts and adding other metals as powders.

More details of the simulant development procedure are given in the following subsections.

\subsubsection{Use of ESP Model Predictions}

The BBIs for all 177 tanks, as of May 2002, were used to provide whole-tank-average composition inputs to the ESP model, which uses thermodynamic data to calculate the liquid and solid phase compositions at equilibrium. This modeling effort (Cowley et al. 2003) was carried out to support the development of a tank-by-tank toxic source term for use in tank farm safety analyses.

The ESP predictions constitute the only phase composition information that was available for Tanks AN-101, C-104, C-111, and C-112. Because the contents of the four tanks have not been changed by retrieval or transfer since 2002, the $2002 \mathrm{BBI}$ information and the ESP predictions based on it are considered an appropriate basis for Simulant 2.

This application of ESP had certain characteristics that should be noted:

(a) ESP was supplied and developed by OLI Systems, Inc., Morris Plains, New Jersey. 
- Compositions were calculated on a whole-tank basis as if all the different layers of waste had been mixed and allowed to come to equilibrium.

- ESP is an equilibrium model and is not expected to predict the correct concentration of any compounds that have not yet come to equilibrium with an in-tank chemical environment different from those in which they formed (e.g., different temperature, $\mathrm{pH}$, etc.).

- In the ESP runs carried out for Cowley et al. (2003), certain compounds were excluded from precipitating to reflect kinetic limitations or sometimes to reduce computational time or avoid nonconvergence of the solution algorithm.

- Because of computational time constraints, reduction oxidation (REDOX) equilibrium was not calculated on a tank-by-tank basis in the 2003 study; rather, expert judgment and generic-composition runs of ESP were used to fix the metal oxidation states in all tanks. Iron was fixed as $\mathrm{Fe}^{+3}$, manganese as $\mathrm{Mr}^{+2}$, chromium as $\mathrm{Cr}^{+3}$ or $\mathrm{Cr}^{+6}, \mathrm{U}_{\text {as }} \mathrm{U}^{+6}$, and so forth. Thus, the ESP predictions did not include compounds formed by metals in any other oxidation states.

- Because the 2003 study was aimed at toxicity assessment, and because the toxicity of organic compounds was calculated outside of ESP, the only organic species used in ESP inputs were oxalate and acetate ions. The former represented all the low-solubility carbon, the latter all the soluble carbon. Other organic species, including complexants, do not appear in the ESP results.

- The study assigned compounds to the trace analytes (including thorium, cadmium, copper, tin, and many others) without employing the ESP model; thus, these metals are not present in the ESPpredictions database.

- Thermodynamic data were not available for all the compounds that could potentially form in the tank waste, which led to the omission of some compounds.

The ESP model, as used, predicted the normalized concentration of each compound in the waste. In other words, the model predicted the relative masses of different compounds and the relative volumes and masses of total liquid and total solid, but not the absolute masses or volumes in a tank. The absolute volume of the dry-solid phase in a tank was calculated for the present study by combining the ESP results with BBI volumes, using the following equation:

$$
\mathrm{V}_{\mathrm{S}}=\mathrm{V} \phi_{\mathrm{ESP}}
$$

where $\mathrm{V}_{\mathrm{S}}$ is the dry-solid volume in the tank, $\phi_{\mathrm{ESP}}$ is the ESP-predicted dry-solid fraction, average of all waste in the tank, and V is the total waste volume in the tank as defined by the BBI.

The solid-phase volume calculated by the above equation contains some uncertainty because of uncertainty in the parameters and because the potential retained gas volume is not accounted for. 


\subsubsection{Combination of Inventories for the Four Tanks of Interest}

The contents of the four tanks of interest were described by the $2002 \mathrm{BBI}$ as

- AN-101: $956 \mathrm{~kL}$ of supernatant with no solids. The BBI did not identify a waste type.

- C-104: $980 \mathrm{~kL}$ of sludge. Aluminum-clad fuel waste from the PUREX process (waste types CWP1 and CWP2), unidentified sludge, organic wash waste from PUREX (OWW3), Zircaloy-clad fuel waste from the PUREX and Zirflex processes (CWZr1), and thorium fuel waste from PUREX (TH2) were listed as contributors, in decreasing order of volume.

- C-111: $217 \mathrm{~kL}$ of sludge. Waste from ferrocyanide scavenging of supernatants (TFeCN), CWP1, waste from the $\mathrm{BiPO}_{4}$ fuel-recovery process (1C), and waste from the hot semiworks pilot plant (HS) were listed as contributors, in decreasing order of volume.

- C-112: $393 \mathrm{~kL}$ of sludge. Waste types TFeCN, CWP1, and1C were listed as contributors, in decreasing order of volume.

The interstitial liquid composition was not given in the BBIs for any of the three $\mathrm{C}$ tanks. The ESP prediction was therefore taken as guidance to the liquid composition.

Table 2.4 gives the bulk compositions that were derived from ESP modeling results for the four tanks. Table 2.5 gives the liquid-phase compositions predicted by ESP and indicates which species were present only in liquid form.

As is shown in Table 2.4, the calculated bulk compositions for Tanks C-111 and C-112 differ from the average tank waste composition in the BBI. This is the result of intentional changes that were made to adapt the BBI average bulk concentrations to the input requirements of ESP. The ESP model requires charge-balanced composition input, and the charge balance of the unadjusted BBI bulk compositions for $\mathrm{C}-111$ and $\mathrm{C}-112$ led to an unreasonably low hydroxide concentration, giving a $\mathrm{pH}$ of less than 7 . The BBI composition was therefore adjusted to contain higher cation concentrations $\left(\mathrm{Na}^{+}\right.$and $\mathrm{K}^{+}$), and, in the case of C-111, lower anion concentrations $\left(\mathrm{NO}_{3}{ }^{-}\right.$and $\left.\mathrm{SiO}_{4}{ }^{-4}\right)$. The adjustment allowed for higher concentrations of free hydroxide, which made up the charge balance.

Another difference from the BBI can be seen in the solids predicted in AN-101. Only liquid was present in AN-101, according to the $2002 \mathrm{BBI}$. The ESP-predicted solids, which are $2.0 \mathrm{wt} \%$ of the inventory, include $\mathrm{Al}(\mathrm{OH})_{3}$ and small contributions from a range of compounds of other metals. The $\mathrm{Al}$ solubility implied by the dissolved Al concentration in the BBI was about triple the ESP prediction: $9914 \mu \mathrm{g} / \mathrm{g}(0.44 \mathrm{M})$, rather than the predicted $3172 \mu \mathrm{g} / \mathrm{g}(0.14 \mathrm{M})$.

It is not clear that the $\mathrm{Al}$ concentrations given in the $\mathrm{BBI}$ came from direct measurements that were made at the BBI's free hydroxide concentration of $16838 \mu \mathrm{g} / \mathrm{g}(1.18 \mathrm{M})$. The BBI was based partly on measurements made in 1998 and partly on additions of water and AX-farm liquid between 1998 and 2002. For comparison, two liquid grab samples taken in 1998 (1AN-98-2 and 1AN-98-3) contained 9430 to $9990 \mu \mathrm{g} / \mathrm{mL}$ of $\mathrm{Al}(0.35$ to $0.37 \mathrm{M})$ in combination with 26700 to $33100 \mu \mathrm{g} / \mathrm{mL}$ of hydroxide (1.57 to $1.95 \mathrm{M})$. The measurements show that about the same concentration of Al as in the BBI was produced by a considerably higher hydroxide concentration. This suggests that the BBI calculations may have made assumptions that overestimated the concentration of Al that could be supported by the BBI-calculated 
hydroxide concentration. On the other hand, the dissolved Al concentrations predicted by ESP seem low; the ratio of $\mathrm{Al} /$ free $\mathrm{OH}$ is less for the ESP predictions than for the grab samples.

The total liquid-phase and solid-phase masses in each tank were calculated by multiplying the BBI total volume by the liquid-phase and solid-phase volume fractions and densities calculated by ESP. The mass inventory of each ESP-predicted compound in each phase was then calculated by multiplying the phase mass by the ESP-predicted compound concentration in the phase. Finally, the analyte inventories in each phase were calculated from the inventories of compounds and summed over all four tanks.

No attempt was made to account for any dissolution or precipitation that might have resulted from mixing the wastes. Hence, the liquid-phase concentrations should not be considered to be specific predictions. Aluminum would be the likeliest candidate for a phase change that would lead to different phase concentrations than those given by a simple summation; fluoride and phosphate are other possibilities. Note, however, that the bulk composition, which is unaffected by precipitation and dissolution, is the information that is relevant to simulant development. As Section 3.2 shows, the simulant makeup process does not depend on the speciation or phase distribution predicted by ESP. 
Table 2.4. ESP-Predicted Bulk Compositions for the Four Tanks

\begin{tabular}{|c|c|c|c|c|}
\hline Analyte & $\begin{array}{l}\text { AN-101 } \\
(\mu \mathrm{g} / \mathrm{g})\end{array}$ & $\begin{array}{l}\text { C-104 } \\
(\mu \mathrm{g} / \mathrm{g}) \\
\end{array}$ & $\begin{array}{l}\mathrm{C}-111 \\
(\mu \mathrm{g} / \mathrm{g}) \\
\end{array}$ & $\begin{array}{l}\text { C-112 } \\
(\mu \mathrm{g} / \mathrm{g}) \\
\end{array}$ \\
\hline $\mathrm{Ag}$ & 5.6 & 640 & 0 & 1.5 \\
\hline $\mathrm{Al}$ & 9924 & 54398 & 91963 & 19720 \\
\hline $\mathrm{Bi}$ & 24 & 29 & 5434 & 3244 \\
\hline $\mathrm{C}_{2} \mathrm{O}_{4}^{-2 \text { (a) }}$ & 0 & 15707 & 1437 & 7051 \\
\hline $\mathrm{Ca}$ & 12 & 1805 & 12862 & 18607 \\
\hline $\mathrm{Cl}^{-}$ & 2038 & 483 & 868 & 846 \\
\hline $\mathrm{CO}_{3}^{-2}$ & 7349 & 29282 & 21704 & 23219 \\
\hline $\mathrm{Cr}$ & 97 & 881 & 274 & 221 \\
\hline $\mathrm{F}$ & 204 & 20888 & 2775 & 677 \\
\hline $\mathrm{Fe}$ & 5.8 & 16663 & 42765 & 21787 \\
\hline $\mathrm{H}_{2} \mathrm{O}$ (free) & 753500 & 471900 & 332300 & 490700 \\
\hline K & 2235 & 803 & $\begin{array}{l}1574^{(b)} \\
(\mathrm{BBI} 926)\end{array}$ & $\begin{array}{r}527^{(\mathrm{b})} \\
(\mathrm{BBI} 477)\end{array}$ \\
\hline $\mathrm{La}$ & 10 & 29 & 338 & 72 \\
\hline $\mathrm{Mn}$ & 2.4 & 4232 & 258 & 196 \\
\hline $\mathrm{Na}$ & 78785 & 107555 & $\begin{array}{r}69448^{(\mathrm{b})} \\
(\mathrm{BBI} 40835)\end{array}$ & $\begin{array}{c}88070^{(\mathrm{b})} \\
(\mathrm{BBI} 79676)\end{array}$ \\
\hline $\mathrm{Ni}$ & 3.3 & 1589 & 15734 & 12381 \\
\hline $\mathrm{NO}_{2}^{-}$ & 36745 & 22037 & 30515 & 44211 \\
\hline $\mathrm{NO}_{3}^{-}$ & 64192 & 11833 & $\begin{array}{r}41207^{(\mathrm{b})} \\
(\mathrm{BBI} 55625)\end{array}$ & 59160 \\
\hline $\mathrm{Pb}$ & 23 & 505 & 4502 & 2354 \\
\hline $\mathrm{PO}_{4}^{-3}$ & 1341 & 1938 & 58200 & 62023 \\
\hline $\mathrm{Si}$ & 38 & 6158 & $\begin{array}{c}5502^{(\mathrm{b})} \\
(\mathrm{BBI} 7427)\end{array}$ & 2465 \\
\hline $\mathrm{SO}_{4}^{-2}$ & 1073 & 2065 & 4791 & 11147 \\
\hline $\mathrm{Sr}$ & 2.4 & 53 & 185 & 307 \\
\hline $\mathrm{TOC}^{(\mathrm{a})}$ & 1045 & 8645 & 791 & 3881 \\
\hline $\mathrm{U}$ & 26 & 21309 & 13664 & 38322 \\
\hline $\mathrm{Zr}$ & 1.1 & 39180 & 171 & 15 \\
\hline $\begin{array}{l}\text { bulk density } \\
(\mathrm{g} / \mathrm{mL})\end{array}$ & 1.20 & 1.55 & 1.69 & 1.47 \\
\hline $\begin{array}{l}\text { solid-phase } \\
\text { density }\end{array}$ & 2.45 & 3.02 & 2.54 & 2.67 \\
\hline
\end{tabular}

(a) In the ESP modeling, the only two species contributing to total organic carbon (TOC) were oxalate $\left(\mathrm{C}_{2} \mathrm{O}_{4}^{-2}\right)$ and acetate $\left(\mathrm{CH} 3 \mathrm{COO}^{-}\right)$, the latter representing the soluble carbon.

(b) ESP requires charge-balanced inputs, and hydroxide was the primary source of charge balance. The charge balance based on anion/cation concentrations in the BBI caused ESP to predict unrealistically low hydroxide $(\mathrm{pH}<7)$. Anions and cations were adjusted in the ESP inputs, as shown, to give a $\mathrm{pH}$ between 10 and 11. The (BBI) entries show the unadjusted values from the BBI. 
Table 2.5. ESP-Predicted Liquid-Phase Compositions for the Four Tanks

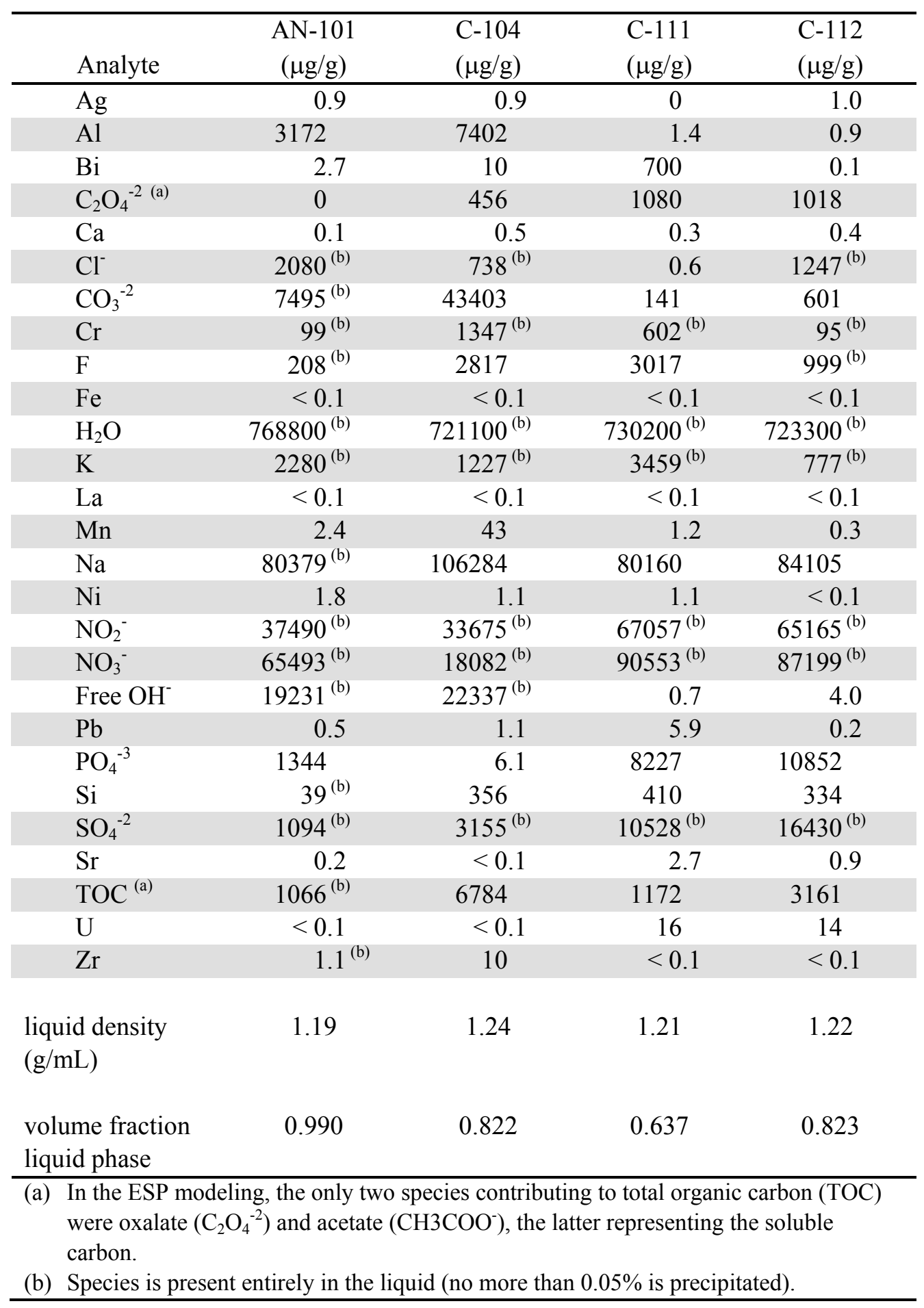


Table 2.6 shows the bulk and liquid-phase analyte concentrations that were calculated for the fourtank mixed waste. The predominant solid compound (more than $30 \mathrm{wt} \%$ of the solid phase) was calculated to be $\mathrm{Al}(\mathrm{OH})_{3}$, Table 2.7 .

Table 2.6. Four-Tank Waste Mixture Composition, from Summing ESP Predictions

\begin{tabular}{|c|c|c|}
\hline Analyte & $\begin{array}{c}\text { Concentration in Bulk } \\
(\mu \mathrm{g} / \mathrm{g})\end{array}$ & $\begin{array}{c}\text { Concentration in Liquid } \\
(\mu \mathrm{g} / \mathrm{g})\end{array}$ \\
\hline $\mathrm{Ag}$ & 271 & 0.9 \\
\hline $\mathrm{Al}$ & 38522 & 4080 \\
\hline $\mathrm{Bi}$ & 1091 & 48 \\
\hline $\mathrm{C}_{2} \mathrm{O}_{4}{ }^{-2}$ (a) & 7881 & 386 \\
\hline $\mathrm{Ca}$ & 5048 & 0.3 \\
\hline $\mathrm{Cl}^{-}$ & 1074 & 1330 \\
\hline $\mathrm{CO}_{3}^{-2}$ & 20571 & 19354 \\
\hline $\mathrm{Cr}$ & 465 & 593 \\
\hline $\mathrm{F}$ & 9240 & 1467 \\
\hline $\mathrm{Fe}$ & 14839 & $<0.1$ \\
\hline $\mathrm{H}_{2} \mathrm{O}$ & 550210 & $741989^{(b)}$ \\
\hline $\mathrm{K}$ & 1292 & 1742 \\
\hline $\mathrm{La}$ & 61 & $<0.1$ \\
\hline $\mathrm{Mn}$ & 1838 & 17 \\
\hline $\mathrm{Na}$ & 91422 & 90523 \\
\hline $\mathrm{Ni}$ & 4249 & 1 \\
\hline $\mathrm{NO}_{2}^{-}$ & 31121 & $41969^{(b)}$ \\
\hline $\mathrm{NO}_{3}^{-}$ & 39031 & $52635^{(b)}$ \\
\hline Free $\mathrm{OH}^{-}$ & --- & $16369^{(b)}$ \\
\hline $\mathrm{Pb}$ & 1054 & 1 \\
\hline $\mathrm{PO}_{4}^{-3}$ & 17079 & 2669 \\
\hline $\mathrm{Si}$ & 3555 & 223 \\
\hline $\mathrm{SO}_{4}^{-2}$ & 3480 & $4694^{(b)}$ \\
\hline $\mathrm{Sr}$ & 91 & 0.4 \\
\hline $\mathrm{TOC}^{(\mathrm{a})}$ & 4670 & 3502 \\
\hline $\mathrm{U}$ & 16494 & 3 \\
\hline $\mathrm{Zr}$ & 16499 & 4 \\
\hline density $(\mathrm{g} / \mathrm{mL})$ & 1.42 & 1.21 \\
\hline volume fraction & --- & 0.74 \\
\hline \multicolumn{3}{|c|}{$\begin{array}{l}\text { (a) In the ESP modeling, the only two species contributing to TOC were oxalate } \\
\left(\mathrm{C}_{2} \mathrm{O}_{4}^{-2}\right) \text { and acetate }\left(\mathrm{CH}_{3} \mathrm{COO}^{-}\right) \text {, the latter representing the soluble carbon. } \\
\text { (b) Species is present entirely in the liquid (no more than } 0.05 \% \text { is precipitated). }\end{array}$} \\
\hline
\end{tabular}


Table 2.7. Four-Tank Waste Primary (Mass Fraction $>0.5$ ) Solid Phase Compound Composition, from Summing ESP Predictions

\begin{tabular}{lcc}
\hline \multicolumn{1}{c}{ Solid Phase Compound } & $\begin{array}{c}\text { Density } \\
(\mathrm{g} / \mathrm{mL})\end{array}$ & $\begin{array}{c}\text { Mass } \\
\text { Fraction }\end{array}$ \\
\hline $\mathrm{Al}(\mathrm{OH})_{3}$ & 2.42 & 0.33 \\
$\mathrm{ZrO}_{2}$ & 5.68 & 0.09 \\
$\mathrm{FeOOH}$ & 4.26 & 0.09 \\
$\mathrm{Na}_{2} \mathrm{U}_{2} \mathrm{O}_{7}$ & 5.62 & 0.08 \\
$\mathrm{NaAlSiO}_{4}$ & 2.59 & 0.07 \\
$\mathrm{NaAlCO}_{3}(\mathrm{OH})_{2}$ & 2.42 & 0.05 \\
\hline
\end{tabular}




\subsection{Simulant Preparation}

Specific preparation is documented for the two sludge simulants. The preparation of Simulant 1 is described in Section 3.1, and that of Simulant 2 in Section 3.2.

\subsection{Simulant 1 Preparation}

Previous work developed a simulant used in the WTP PEP ultra-filtration testing and is known as the CBM-3 simulant (Russell et al. 2009a). The CBM-3 simulant was selected as Simulant 1 for the current work as described in Section 2 and consists of a complex hydroxide precipitation methodology to produce the iron-bearing portion of the simulant, which is representative of the method by which this phase was formed in the HLW tanks, along with an anion-bearing supernate. Simulant 1 also contains a blend of commercially available materials, including sodium oxalate, boehmite, and gibbsite.

The iron-bearing portion of Simulant 1 represents the hydroxide waste phases that formed in the tank waste when metal nitrate solutions (mainly iron) were treated with caustic to minimize corrosion (Gephart and Lundgren 2005). The composition of this portion of the simulant was simplified by removing minor elements that were also toxic. No aging of the iron-bearing portion, such as the heat treatment performed by Stewart et al. (2007), was conducted. The iron-bearing portion of the simulant was based on the composition of the AY-102/C-106 tank waste sludge, minus the gibbsite, boehmite, chromium, and minor metals, and was prepared as described by Zamecnik et al. (2004), having the components listed in Table 3.1 and Table 3.2 .

Table 3.1 shows the postulated UDS chemical components of the iron-bearing sludge portion of the simulant, which consists primarily of iron. The insoluble hydroxide solids are produced when $\mathrm{NaOH}$ is added to a metal nitrate solution, increasing the $\mathrm{pH}$ to between 10 and 11 . The $\mathrm{KMnO}_{4}$ and $\mathrm{Mn}\left(\mathrm{NO}_{3}\right)_{2}$ are pre-reacted to produce insoluble $\mathrm{MnO}_{2}$ before the nitrate salts are added by mixing them together in deionized water. The excess nitrate is then washed from the slurry using the simple supernate described in Appendix A. Table 3.2 shows the chemical components used to produce the final supernate simulant and includes both the nitrate and non-nitrate anions present in the waste. The recipe used to make the iron-bearing and supernate simulant portions of Simulant 1 is provided as Appendix A.

Gibbsite, boehmite, and sodium oxalate were added to the iron-bearing and supernatant simulants. Sodium oxalate is included in the solids phase of the simulant for several reasons. It is one of the principal organic salts in the Hanford wastes. In general, oxalates have a low solubility and are temperature sensitive compared to other salts in the waste and oxalate complexes with ferric iron to form a soluble iron complex. In the simulant, it is used to also represent all of the minor water-soluble constituents of the solids phase such as the carbonates, sulfates, phosphates, oxalates, and fluoridephosphates (Smith et al. 2009). The component masses to produce nominally $5 \mathrm{~L}$ of Simulant 1 at approximately $40 \mathrm{wt} \%$ UDS are provided in Appendix B. Also provided in Appendix B are the manufacturer characterizations of the primary solid-phase compounds gibbsite and boehmite. 
Table 3.1. Postulated Composition of Iron-Rich Sludge (Russell et al. 2009a)

\begin{tabular}{cc}
\hline $\begin{array}{c}\text { Expected } \\
\text { Constituent }\end{array}$ & $\begin{array}{c}\text { Chemical } \\
\text { Components } \\
\text { (mol fraction) }\end{array}$ \\
\hline $\mathrm{Ba}(\mathrm{OH})_{2}$ & 0.0019 \\
$\mathrm{Ca}(\mathrm{OH})_{2}$ & 0.0235 \\
$\mathrm{Cd}(\mathrm{OH})_{2}$ & 0.0006 \\
$\mathrm{Ce}(\mathrm{OH})_{3}$ & 0.0034 \\
$\mathrm{Cu}(\mathrm{OH})_{2}$ & 0.0015 \\
$\mathrm{Fe}(\mathrm{OH})_{3}$ & 0.7269 \\
$\mathrm{La}(\mathrm{OH})_{3}$ & 0.0025 \\
$\mathrm{~Pb}(\mathrm{OH})_{2}$ & 0.0090 \\
$\mathrm{Mg}(\mathrm{OH})_{2}$ & 0.0153 \\
$\mathrm{Nd}(\mathrm{OH})_{3}$ & 0.0069 \\
$\mathrm{Ni}(\mathrm{OH})_{2}$ & 0.0226 \\
$\mathrm{Pr}(\mathrm{OH})_{3}$ & 0.0017 \\
$\mathrm{RuOOH}$ & 0.0013 \\
$\mathrm{AgOH}$ & 0.0066 \\
$\mathrm{kSr}(\mathrm{OH})_{2}$ & 0.0038 \\
$\mathrm{Y}(\mathrm{OH})_{3}$ & 0.0008 \\
$\mathrm{Zn}(\mathrm{OH})_{2}$ & 0.0013 \\
$\mathrm{ZrO}(\mathrm{OH})_{2}$ & 0.0117 \\
$\mathrm{Hg}(\mathrm{OH})_{2}$ & 0.0004 \\
$\mathrm{MnO}{ }_{2}$ & 0.1584 \\
\hline & \\
\hline
\end{tabular}

Table 3.2. Chemical Components Used to Produce Supernate Simulant (Russell et al. 2009a)

\begin{tabular}{lcc}
\hline Chemical Constituent & $\begin{array}{c}\text { Compound } \\
\text { Formula }\end{array}$ & $\begin{array}{c}\text { Concentration } \\
(\mathrm{g} / \mathrm{kg})\end{array}$ \\
\hline Potassium nitrate & $\mathrm{KNO}_{3}$ & 0.4235 \\
Sodium phosphate & $\mathrm{Na}_{3} \mathrm{PO}_{4} \bullet 12 \mathrm{H}_{2} \mathrm{O}$ & 15.38 \\
Sodium metasilicate & $\mathrm{Na}_{2} \mathrm{SiO}_{3} \cdot 9 \mathrm{H}_{2} \mathrm{O}$ & 0.5455 \\
Sodium sulfate & $\mathrm{Na}_{2} \mathrm{SO}_{4}$ & 2.671 \\
Sodium hydroxide & $\mathrm{NaOH}_{3}$ & 15.38 \\
Sodium acetate & $\mathrm{NaCH}_{3} \mathrm{COO} \cdot 3 \mathrm{H}_{2} \mathrm{O}$ & 1.034 \\
Sodium oxalate & $\mathrm{Na}_{2} \mathrm{C}_{2} \mathrm{O}_{4}$ & 5.303 \\
Sodium nitrite & $\mathrm{NaNO}_{2}$ & 6.494 \\
\hline
\end{tabular}




\subsection{Simulant 2 Preparation}

Simulant 2, whose composition is based on the four-tank waste mixture described by Table 2.4, was produced via a four-step procedure:

1) Create a simulant of the sodium salts present in the four-tank mixed waste. This salt slurry is made up from water and sodium acetate, oxalate, chloride, carbonate, fluoride, nitrite, nitrate, phosphate, and sulfate. The recipe for this salt slurry is calculated from the bulk concentrations of TOC, $\mathrm{C}_{2} \mathrm{O}_{4}{ }^{-2}$, $\mathrm{Cl}^{-}, \mathrm{CO}_{3}^{-2}, \mathrm{~F}^{-}, \mathrm{NO}_{2}^{-}, \mathrm{NO}_{3}^{-}, \mathrm{PO}_{4}^{-3}$, and $\mathrm{SO}_{4}^{-2}$.

2) Add hydroxide to a mixture of acid nitrates of the metals $\mathrm{Ni}, \mathrm{Fe}, \mathrm{Nd}, \mathrm{Mn}$, and $\mathrm{Ca}$. Neodymium is used as a surrogate for uranium. The recipe for this slurry of metal hydroxides and oxides is calculated from the bulk concentrations of $\mathrm{Ni}, \mathrm{Fe}, \mathrm{U}, \mathrm{Mn}$, and $\mathrm{Ca}$. Manganese is added in the $\mathrm{Mn}$ (II) oxidation state.

3) Combine the slurries produced by Steps (1) and (2).

4) $\mathrm{Add} \mathrm{Al}(\mathrm{OH})_{3}, \mathrm{ZrO}_{2}$, and $\mathrm{SiO}_{2}$ as powders; some portion of these powders is expected to dissolve as with Simulant 1. The amounts of powders added are based on the bulk concentrations of Al, Zr, and Si.

This approach was used to produce some of the solids in the same general manner in which they formed in the tanks through precipitation when hydroxide was added to a solution of nitrates. The recipe used to prepare Simulant 2 is provided as Appendix C. The component masses to produce nominally $15 \mathrm{~L}$ of Simulant 2 at approximately $23 \mathrm{wt} \%$ UDS are provided the Appendix as well. 



\subsection{Simulant Properties}

Material properties for Simulants 1 and 2 are listed together with, where applicable, the comparative Hanford sludge properties. The material properties considered include the chemical composition, liquid density, viscosity, and $\mathrm{pH}$, UDS particle size and density, and slurry rheology. The shear modulus of the simulants is estimated. Settling data are also presented, and particle images are shown. The influence of these properties on the lateral earth pressure at rest and shear modulus is discussed in Section 1. Unless otherwise referenced, Simulant 1 and Hanford sludge data are from Section 2, and Simulant 2 data are from the current analysis. Where pertinent, the instrumentation used to perform the measurements is listed together with the operational procedure. Significant figures and uncertainties were not tracked nor reported.

\subsection{Chemical Composition}

The analyte concentrations for the liquid phase of Simulants 1 and 2 are provided in Table 4.1 and Table 4.2, respectively. The Simulant 2 liquid composition for the SST retrieval scenario (Section 2.3, Table 2.6) is included for comparison. The slurry phase composition of Simulant 1 is provided in Table 4.3, and the slurry phase composition of Simulant 2 together with the SST retrieval scenario slurry composition (Section 2.3, Table 2.6) are provided in Table 4.4. The composition of Simulant 2 is shown to compare well with the SST retrieval scenario considered in Section 2.3.

Table 4.2 and Table 4.4 each contain a column that shows how each species concentration, when normalized using one of the other major constituents, compares to expectations. The normalization makes up for any variation caused by having more, or less, water present in the simulant than in the Table 2.6 compositions.

In the case of liquid-phase concentrations (Table 4.2), nitrite is used to normalize the other dissolved species. Nitrite is expected to be completely soluble. The dissolved concentrations of sodium, chloride, and sulfate all match the expectations within about $10 \%$. The somewhat high potassium in the liquid ( $48 \%$ high) may have come from trace contamination of reagents with potassium. Oxalate, aluminum, fluoride, and phosphate all apparently have different solubilities than the Table 2.6 estimates (data included in Table 4.2), which were based on taking a weighted sum of the ESP-predicted dissolved concentrations for the four sludge tanks (giving the values in Table 2.6). This difference from the Table 2.6 results is not surprising since the solubility of a species in a mixture of liquids can be nonlinearly different than the solubility in each liquid. Finally, the nitrate in the liquid is more than double the expected concentration. This is the result not of a solubility difference, but of unavoidable excess nitrate from the metal nitrates used as reagents to produce the simulant.

In the case of slurry concentrations (Table 4.4), iron is used to normalize the other species. Iron is expected to be effectively insoluble. The normalized concentrations of all the analyzed species in the simulant are within about $10 \%$ of the values based on Table 2.6 (data included in Table 4.4), except in the case of potassium. As already stated, the increase in potassium may have come from trace contaminants in the reagents. 
Selected primary solid-phase compounds and concentrations based on the simulant production (see Sections 2 and 3) are provided in Table 4.5 for Simulants 1 and 2, respectively. Comparative Hanford sludge solid-phase compounds and concentrations are also provided (Wells et al. 2007). The simulants are postulated to represent the primary solid-phase compounds of the actual waste reasonably well. Thus, it may be reasonable to expect that the particle densities and shapes are similar (see Section 1). The particle shapes are qualitatively compared in Section 4.7.

The UDS concentration of the as-prepared simulants was determined by drying as per RPLCOLLOID-02 (Daniel 2007). Simulant 1 was prepared at a measured UDS mass fraction ( $\mathrm{w}_{\mathrm{S}}$ ) of 0.31 and Simulant 2 at 0.23 . The bulk densities $\left(\rho_{\mathrm{B}}\right)$ at these concentrations were measured at $1.483 \mathrm{~g} / \mathrm{mL}$ and $1.398 \mathrm{~g} / \mathrm{mL}$, respectively (measured per Daniel 2007). The bulk density of the UDS in the slurry, $\rho_{\mathrm{S}}$, may then be computed from the conservation of mass as

$$
\rho_{\mathrm{S}}=\frac{\mathrm{w}_{\mathrm{S}} \rho_{\mathrm{B}}}{1-\frac{\rho_{\mathrm{B}}}{\rho_{\mathrm{L}}}\left(1-\mathrm{w}_{\mathrm{S}}\right)}
$$

where $\rho_{\mathrm{L}}$ is the liquid density (see Table 4.7, Section 4.2). The bulk UDS densities are computed as $2.78 \mathrm{~g} / \mathrm{mL}$ for Simulant 1 and $2.56 \mathrm{~g} / \mathrm{mL}$ for Simulant 2 . These values compare very favorably with the values provided in Wells et al. (2007). 
Table 4.1. Liquid Phase Composition, Simulant 1

\begin{tabular}{|c|c|c|}
\hline & Constituent $^{(\mathrm{d})}$ & $\begin{array}{l}\text { Concentration } \\
(\mu \mathrm{g} / \mathrm{mL})^{(a)}\end{array}$ \\
\hline & $\mathrm{Al}$ & 145 \\
\hline & $\mathrm{Ca}$ & $<0.22$ \\
\hline & $\mathrm{Cr}$ & 0.38 \\
\hline & $\mathrm{Fe}$ & $<0.05$ \\
\hline & $\mathrm{Pb}$ & $<0.39$ \\
\hline & $\mathrm{Mg}$ & $\mathrm{NA}^{(\mathrm{c})}$ \\
\hline & $\mathrm{Mn}$ & $<0.005$ \\
\hline & $\mathrm{Ni}$ & $\mathrm{NA}^{(\mathrm{c})}$ \\
\hline & K & 98 \\
\hline & $\mathrm{Na}$ & 5,300 \\
\hline & $\mathrm{Zr}$ & $<0.02$ \\
\hline & $\mathrm{C}_{2} \mathrm{O}_{4}$ & 795 \\
\hline & $\mathrm{NO}_{2}$ & 7,560 \\
\hline & $\mathrm{NO}_{3}$ & 24,100 \\
\hline & $\mathrm{PO}_{4}$ & 439 \\
\hline & $\mathrm{SO}_{4}$ & 889 \\
\hline & TIC & NR \\
\hline & TOC & NR \\
\hline & $\mathrm{OH}$ & NR \\
\hline (a) & \multirow{3}{*}{\multicolumn{2}{|c|}{$\begin{array}{l}\text { The analytical data (Russell et al. 2009c) were } \\
\text { reported per gram of original solution. } \\
\text { The analytical data were less than the method } \\
\text { detection limit (MDL). } \\
\text { Not Applicable (NA) due to sample preparation }\end{array}$}} \\
\hline (b) & & \\
\hline (c) & & \\
\hline (d) & \multicolumn{2}{|c|}{ Certain constituents were not requested (NR). } \\
\hline
\end{tabular}


Table 4.2. Liquid Phase Composition, Simulant 2

\begin{tabular}{|c|c|c|c|}
\hline \multirow[b]{2}{*}{ Constituent $^{(\mathrm{d})}$} & \multicolumn{2}{|c|}{ Concentration $(\mu \mathrm{g} / \mathrm{g})$} & \multirow{2}{*}{$\begin{array}{l}\text { Ratio of (species } / \mathrm{NO}_{2}^{-} \text {) } \\
\text { in analyzed liquid to the } \\
\text { value based on Table } 2.6\end{array}$} \\
\hline & As Analyzed ${ }^{(a)}$ & Table 2.6 & \\
\hline $\mathrm{Ag}$ & $<0.24^{(\mathrm{b})}$ & 0.9 & $\mathrm{n} / \mathrm{c}^{(\mathrm{e})}$ \\
\hline $\mathrm{Al}$ & 255 & 4080 & 0.067 \\
\hline $\mathrm{Bi}$ & $<2.9$ & 48 & $\mathrm{n} / \mathrm{c}^{(\mathrm{e})}$ \\
\hline $\mathrm{C}_{2} \mathrm{O}_{4}^{-2}$ & 781 & 386 & 2.16 \\
\hline $\mathrm{Ca}$ & $1.3^{(\mathrm{c})}$ & 0.3 & $\mathrm{n} / \mathrm{c}^{(\mathrm{e})}$ \\
\hline $\mathrm{Cl}^{-}$ & 1380 & 1330 & 1.11 \\
\hline $\mathrm{CO}_{3}^{-2}$ & $\mathrm{NR}^{(\mathrm{d})}$ & 19354 & $\mathrm{n} / \mathrm{c}^{(\mathrm{e})}$ \\
\hline $\mathrm{Cr}$ & $<0.44$ & 593 & $\mathrm{n} / \mathrm{c}^{(\mathrm{e})}$ \\
\hline $\mathrm{F}$ & 3463 & 1467 & 2.52 \\
\hline $\mathrm{Fe}$ & $<0.21$ & $<0.1$ & $\mathrm{n} / \mathrm{c}^{(\mathrm{e})}$ \\
\hline $\mathrm{H}_{2} \mathrm{O}$ & $\mathrm{NR}^{(\mathrm{d})}$ & 741989 & $\mathrm{n} / \mathrm{c}^{(\mathrm{e})}$ \\
\hline K & 2413 & 1742 & 1.48 \\
\hline $\mathrm{La}$ & $<0.25$ & $<0.1$ & $\mathrm{n} / \mathrm{c}^{(\mathrm{e})}$ \\
\hline $\mathrm{Mn}$ & $<0.05$ & 17 & $\mathrm{n} / \mathrm{c}^{(\mathrm{e})}$ \\
\hline $\mathrm{Na}$ & 86364 & 90523 & 1.02 \\
\hline $\mathrm{Nd}$ & $\mathrm{NR}^{(\mathrm{d})}$ & (f) & $\mathrm{n} / \mathrm{c}^{(\mathrm{e})}$ \\
\hline $\mathrm{Ni}$ & $0.49^{(\mathrm{c})}$ & 1 & $\mathrm{n} / \mathrm{c}^{(\mathrm{e})}$ \\
\hline $\mathrm{NO}_{2}^{-}$ & 39339 & 41969 & $\mathrm{n} / \mathrm{c}^{(\mathrm{e})}$ \\
\hline $\mathrm{NO}_{3}^{-}$ & 116529 & 52635 & 2.36 \\
\hline Free $\mathrm{OH}^{-}$ & $\mathrm{NR}^{(\mathrm{d})}$ & 16369 & $\mathrm{n} / \mathrm{c}^{(\mathrm{e})}$ \\
\hline $\mathrm{Pb}$ & $<2.5$ & 1 & $\mathrm{n} / \mathrm{c}^{(\mathrm{e})}$ \\
\hline $\mathrm{PO}_{4}^{-3}$ & 1281 & 2669 & 0.51 \\
\hline $\mathrm{Si}$ & $9.1^{(\mathrm{c})}$ & 223 & $\mathrm{n} / \mathrm{c}^{(\mathrm{e})}$ \\
\hline $\mathrm{SO}_{4}^{-2}$ & 3942 & 4694 & 0.90 \\
\hline $\mathrm{Sr}$ & $0.0071^{(\mathrm{c})}$ & 0.4 & $\mathrm{n} / \mathrm{c}^{(\mathrm{e})}$ \\
\hline TOC & $\mathrm{NR}^{(\mathrm{d})}$ & 3502 & $\mathrm{n} / \mathrm{c}^{(\mathrm{e})}$ \\
\hline U & $<2.8$ & 3 & $\mathrm{n} / \mathrm{c}^{(\mathrm{e})}$ \\
\hline $\mathrm{Zr}$ & $1.2^{(\mathrm{c})}$ & 4 & $\mathrm{n} / \mathrm{c}^{(\mathrm{e})}$ \\
\hline \multicolumn{4}{|c|}{$\begin{array}{l}\text { (a) The analytical data (ASR } 8558 \text { ) were reported per } \mathrm{mL} \text { of original solution and converted using a } \\
\text { liquid density of } 1.21 \mathrm{~g} / \mathrm{mL} \text {. } \\
\text { (b) The "<" symbol indicates that the analytical data were less than the Method Detection Limit } \\
\text { (MDL). } \\
\text { (c) The analytical data were greater than the Method Detection Limit (MDL) but less than the } \\
\text { Estimated Quantification Limit (EQL). } \\
\text { (d) Certain constituents were not requested (NR). } \\
\text { (e) Ratio was not calculated. } \\
\text { (f) In the simulant, Nd was a substitute for U. }\end{array}$} \\
\hline
\end{tabular}


Table 4.3. Slurry Phase Composition, Simulant 1

\begin{tabular}{|c|c|}
\hline Constituent & $\begin{array}{c}\text { Concentration } \\
(\mu \mathrm{g} / \mathrm{g})^{(\mathrm{a})}\end{array}$ \\
\hline $\mathrm{Ag}$ & 107 \\
\hline $\mathrm{Al}$ & 33,400 \\
\hline $\mathrm{Ba}$ & $343^{(b)}$ \\
\hline $\mathrm{Ca}$ & $<4660$ \\
\hline $\mathrm{Ce}$ & $61^{(b)}$ \\
\hline $\mathrm{Cd}$ & $<12.3$ \\
\hline $\mathrm{Cr}$ & 136 \\
\hline $\mathrm{Cu}$ & $43^{(b)}$ \\
\hline $\mathrm{Fe}$ & $6,900^{(\mathrm{b})}$ \\
\hline $\mathrm{K}$ & $\mathrm{NA}^{(\mathrm{c})}$ \\
\hline $\mathrm{La}$ & $48^{(b)}$ \\
\hline $\mathrm{Mg}$ & $83^{(b)}$ \\
\hline $\mathrm{Mn}$ & 1,490 \\
\hline $\mathrm{Na}$ & 304,000 \\
\hline $\mathrm{Ni}$ & $\mathrm{NA}^{(\mathrm{c})}$ \\
\hline $\mathrm{Nd}$ & $120^{(b)}$ \\
\hline $\mathrm{P}$ & $1,300^{(b)}$ \\
\hline $\mathrm{Pb}$ & $460^{(b)}$ \\
\hline $\mathrm{S}$ & $1,500^{(b)}$ \\
\hline $\mathrm{Sr}$ & 54.3 \\
\hline $\mathrm{Zn}$ & $56^{(\mathrm{b})}$ \\
\hline $\mathrm{Zr}$ & $61^{(\mathrm{b})}$ \\
\hline $\mathrm{C}_{2} \mathrm{O}_{4}$ & $\mathrm{NR}^{(\mathrm{d})}$ \\
\hline $\mathrm{NO}_{2}$ & $\mathrm{NR}^{(\mathrm{d})}$ \\
\hline $\mathrm{NO}_{3}$ & $\mathrm{NR}^{(\mathrm{d})}$ \\
\hline $\mathrm{PO}_{4}$ & $\mathrm{NR}^{(\mathrm{d})}$ \\
\hline $\mathrm{SO}_{4}$ & $\mathrm{NR}^{(\mathrm{d})}$ \\
\hline TIC & $\mathrm{NR}^{(\mathrm{d})}$ \\
\hline TOC & $\mathrm{NR}^{(\mathrm{d})}$ \\
\hline $\mathrm{OH}$ & $\mathrm{NR}^{(\mathrm{d})}$ \\
\hline
\end{tabular}

(a) The analytical data are reported per gram of original slurry. Project records for Russell et al. (2009c).

(b) The analytical results are greater than the MDL but less than the estimated quantification limit (EQL).

(c) Not Applicable due to potassium hydroxide $(\mathrm{KOH})$ fusion.

(d) Not Reported. 
Table 4.4. Slurry Phase Composition, Simulant 2

\begin{tabular}{|c|c|c|c|}
\hline \multirow[b]{2}{*}{ Constituent } & \multicolumn{2}{|c|}{ Concentration $(\mu \mathrm{g} / \mathrm{g})$} & \multirow{2}{*}{$\begin{array}{c}\text { Ratio of (species/Fe) in } \\
\text { analyzed slurry to the value } \\
\text { based on Table } 2.6\end{array}$} \\
\hline & As Analyzed $^{(\mathrm{a})}$ & Table 2.6 & \\
\hline $\mathrm{Ag}$ & $<0.58^{(\mathrm{b})}$ & 271 & $\mathrm{n} / \mathrm{c}^{(\mathrm{e})}$ \\
\hline $\mathrm{Al}$ & 36050 & 38522 & 1.03 \\
\hline $\mathrm{Bi}$ & $<7.0$ & 1091 & $\mathrm{n} / \mathrm{c}^{(\mathrm{e})}$ \\
\hline $\mathrm{C}_{2} \mathrm{O}_{4}^{-2(\mathrm{a})}$ & $\mathrm{NR}^{(\mathrm{d})}$ & 7881 & $\mathrm{n} / \mathrm{c}^{(\mathrm{e})}$ \\
\hline $\mathrm{Ca}$ & 4670 & 5048 & 1.02 \\
\hline $\mathrm{Cl}^{-}$ & $\mathrm{NR}^{(\mathrm{d})}$ & 1074 & $\mathrm{n} / \mathrm{c}^{(\mathrm{e})}$ \\
\hline $\mathrm{CO}_{3}{ }^{-2}$ & $\mathrm{NR}^{(\mathrm{d})}$ & 20571 & $\mathrm{n} / \mathrm{c}^{(\mathrm{e})}$ \\
\hline $\mathrm{Cr}$ & 11(b) & 465 & $\mathrm{n} / \mathrm{c}^{(\mathrm{e})}$ \\
\hline $\mathrm{F}$ & $\mathrm{NR}^{(\mathrm{d})}$ & 9240 & $\mathrm{n} / \mathrm{c}^{(\mathrm{e})}$ \\
\hline $\mathrm{Fe}$ & 13500 & 14839 & $\mathrm{n} / \mathrm{c}^{(\mathrm{e})}$ \\
\hline $\mathrm{H}_{2} \mathrm{O}$ & NR & 550210 & $\mathrm{n} / \mathrm{c}^{(\mathrm{e})}$ \\
\hline $\mathrm{K}$ & 1635 & 1292 & 1.39 \\
\hline $\mathrm{La}$ & 7.8 & 61 & $\mathrm{n} / \mathrm{c}^{(\mathrm{e})}$ \\
\hline Mn & 1775 & 1838 & 1.06 \\
\hline $\mathrm{Na}$ & 79600 & 91422 & 0.96 \\
\hline $\mathrm{Nd}$ & 8335 & (f) & 0.92 \\
\hline $\mathrm{Ni}$ & 3945 & 4249 & 1.02 \\
\hline $\mathrm{NO}_{2}^{-}$ & $\mathrm{NR}^{(\mathrm{d})}$ & 31121 & $\mathrm{n} / \mathrm{c}^{(\mathrm{e})}$ \\
\hline $\mathrm{NO}_{3}^{-}$ & $N^{(d)}$ & 39031 & $\mathrm{n} / \mathrm{c}^{(\mathrm{e})}$ \\
\hline Free $\mathrm{OH}^{-}$ & $\mathrm{NR}^{(\mathrm{d})}$ & --- & $\mathrm{n} / \mathrm{c}^{(\mathrm{e})}$ \\
\hline $\mathrm{Pb}$ & $\mathrm{NR}^{(\mathrm{d})}$ & 1054 & $\mathrm{n} / \mathrm{c}^{(\mathrm{e})}$ \\
\hline $\mathrm{PO}_{4}^{-3}$ & $15256^{(\mathrm{g})}$ & 17079 & 0.98 \\
\hline $\mathrm{Si}$ & 3595 & 3555 & 1.11 \\
\hline $\mathrm{SO}_{4}^{-2}$ & $2939^{(\mathrm{g})}$ & 3480 & 0.93 \\
\hline $\mathrm{Sr}$ & $<0.01$ & 91 & $\mathrm{n} / \mathrm{c}^{(\mathrm{e})}$ \\
\hline $\mathrm{TOC}^{(\mathrm{a})}$ & $\mathrm{NR}^{(\mathrm{d})}$ & 4670 & $\mathrm{n} / \mathrm{c}^{(\mathrm{e})}$ \\
\hline $\mathrm{U}$ & $<6.7$ & 16494 & $\mathrm{n} / \mathrm{c}^{(\mathrm{e})}$ \\
\hline $\mathrm{Zr}$ & 15100 & 16499 & 1.01 \\
\hline
\end{tabular}

(a) The analytical data (ASR 8558) were reported per g of original slurry.

(b) The "<" symbol indicates that the analytical data were less than the Method Detection Limit (MDL).

(c) The analytical data were greater than the Method Detection Limit (MDL) but less than the Estimated Quantification Limit (EQL).

(d) Certain constituents were not requested (NR).

(e) Ratio was not calculated.

(f) In the simulant, $\mathrm{Nd}$ was a substitute for $\mathrm{U}$. The normalized concentration ratio is calculated in terms of moles of $\mathrm{Nd}$ in the simulant versus moles of $\mathrm{U}$ in Table 2.6.

(g) The phosphate and sulfate concentrations in the slurry are derived, respectively, from ICP analyses of P and $\mathrm{S}$. 
Table 4.5. Selected Postulated Primary UDS Solid Phase Compounds

\begin{tabular}{|c|c|c|c|c|}
\hline & & $\begin{array}{l}\text { Hanford } \\
\text { Sludge }\end{array}$ & Simulant 1 & Simulant 2 \\
\hline Solid Phase Compound & $\begin{array}{l}\text { Density } \\
(\mathrm{g} / \mathrm{mL})\end{array}$ & $\begin{array}{l}\text { UDS Mass } \\
\text { Fraction }\end{array}$ & $\begin{array}{l}\text { UDS Mass } \\
\text { Fraction }\end{array}$ & $\begin{array}{l}\text { UDS Mass } \\
\text { Fraction }\end{array}$ \\
\hline $\mathrm{Al}(\mathrm{OH})_{3}$ & 2.42 & 0.449 & 0.355 & 0.33 \\
\hline $\mathrm{AlOOH}$ & 3.01 & 0.115 & 0.355 & \\
\hline $\mathrm{Fe}_{2} \mathrm{O}_{3}$ & 5.24 & 0.078 & & \\
\hline $\mathrm{FeOOH}$ & 4.26 & & & 0.09 \\
\hline $\mathrm{Fe}(\mathrm{OH})_{3}$ & 3.12 & & 0.14 & \\
\hline $\mathrm{ZrO}_{2}$ & 5.68 & 0.022 & & 0.09 \\
\hline
\end{tabular}

Further insight into the UDS solid phases of the simulants is gained via X-ray diffraction (XRD) and scanning electron microscopy (SEM) electron dispersive spectroscopy (EDS) elemental analysis. The XRD sample results for the simulant material used in the PEP simulant, representing Simulant 1, are shown in Figure 4.1 (Geeting et al. 2009). The XRD sample was prepared by drying a portion of the Simulant 2 slurry at $\sim 105^{\circ} \mathrm{C}$ overnight. The dried material was ground into a fine powder with an agate mortar and pestle. The powder was mounted into a plastic holder and scanned from 5 to $70^{\circ} 2 \theta$ with a step size of $0.015^{\circ} 2 \theta$ and a hold time of $0.3 \mathrm{sec} / \mathrm{step}$ using a Bruker D-8 advanced system equipped with a LynxEye 1-dimensional detector with an angular range of $3.5^{\circ} 2 \theta$.

The identified phases in Figure 4.1 included gibbsite $\left(\mathrm{Al}(\mathrm{OH})_{3}\right)$, boehmite $(\mathrm{AlOOH})$, and rutile $\left(\mathrm{TiO}_{2}\right)$ added as an internal standard, and excepting the standard, are consistent with several of the major chemicals used to prepare the simulant as described in Section 3. The identified phases are consistent with the aluminum species used to prepare the simulant. 


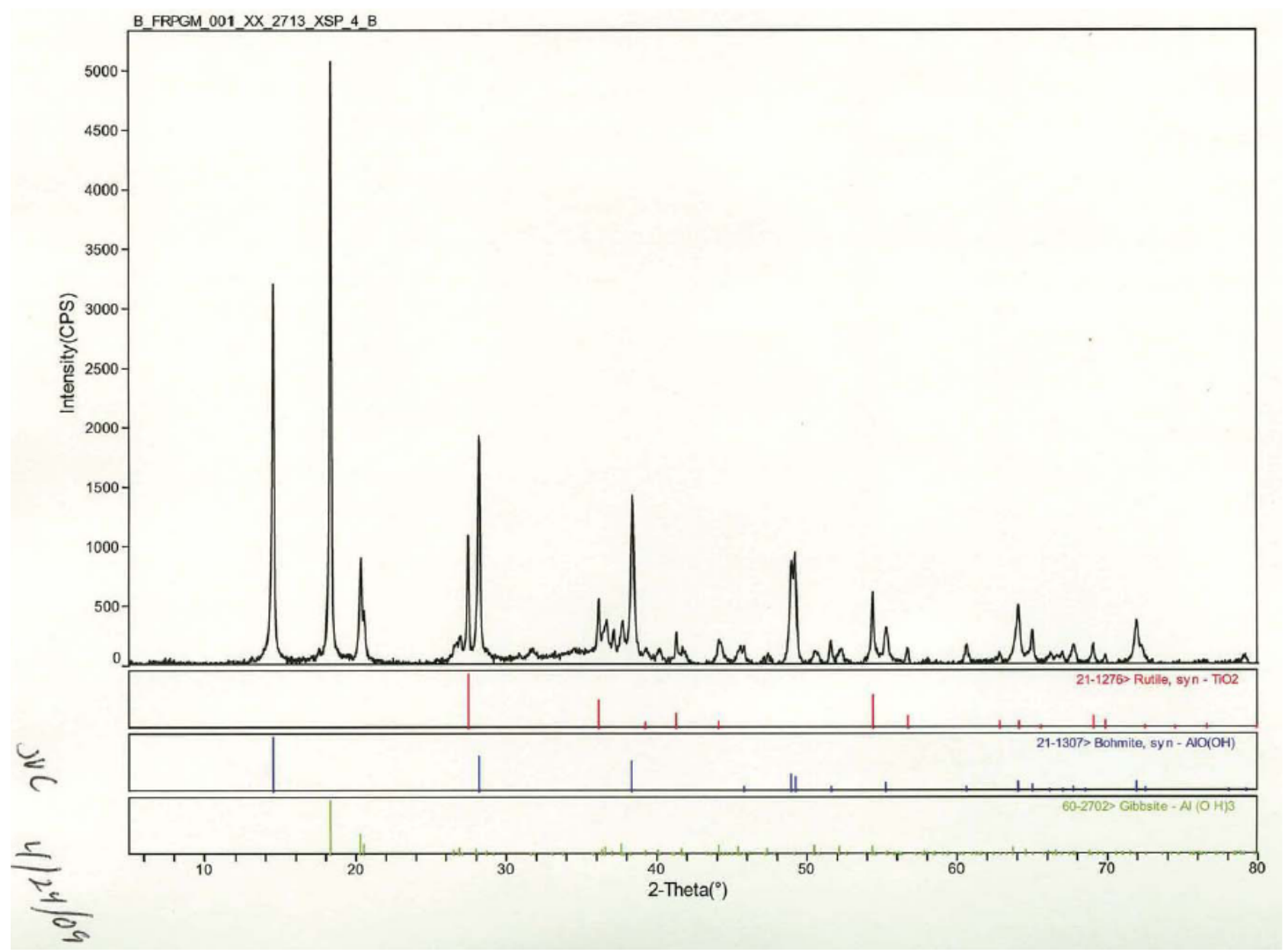

Figure 4.1. Simulant 1 XRD Results with Peak Identification (PEP simulant, Geeting et al. 2009)

The XRD sample results for Simulant 2 are shown in Figure 4.2. The identified phases included baddeleyite $\left(\mathrm{ZrO}_{2}\right)$, gibbsite $\left(\mathrm{Al}(\mathrm{OH})_{3}\right)$, nitratine $\left(\mathrm{NaNO}_{3}\right)$, quartz $\left(\mathrm{SiO}_{2}\right)$, and sodium nitrite $\left(\mathrm{NaNO}_{2}\right)$. These phases are consistent with several of the major chemicals used to prepare the simulant, Section 3. Figure 4.1 and Figure 4.2 show similar peak profiles because of common components, but also contain stark differences because of differences in the presence of certain components (e.g., boehmite). 


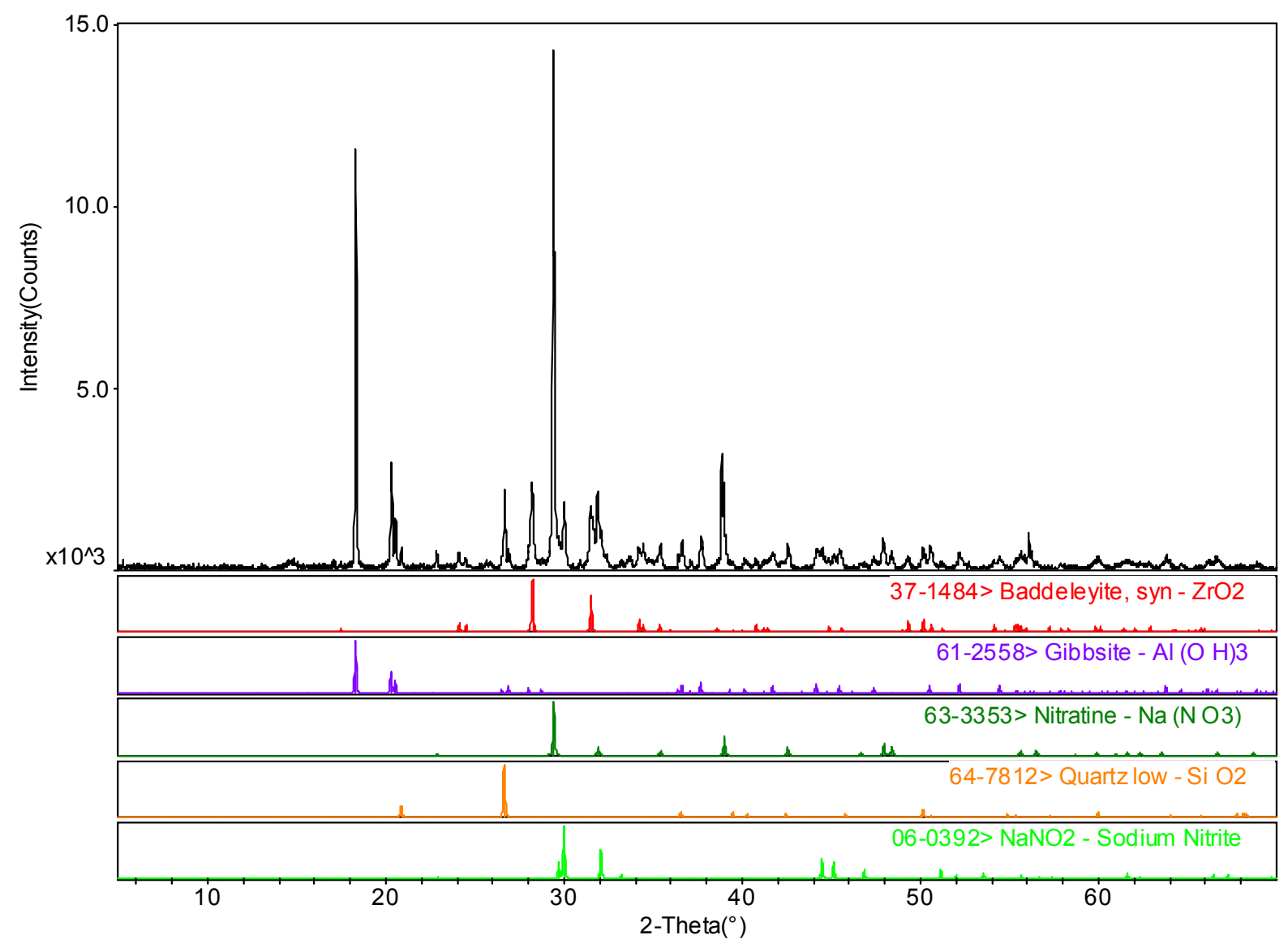

Figure 4.2. Simulant 2 XRD Results with Peak Identification

The SEM elemental analysis results for Simulant 2 are shown graphically in Figure 4.3 and numerically in Table 4.6. Figure 4.3 shows the SEM image of the sample location from where the elemental analysis data were collected. The numeric data indicate that a substantial majority of the sample contains oxygen and sodium followed by lesser amounts of aluminum and iron and significantly smaller amounts of other simulant components. The data are consistent with the simulant composition (e.g., significant amounts of $\mathrm{NaNO}_{3}, \mathrm{NaNO}_{2}, \mathrm{Al}(\mathrm{OH})_{3}$, and $\mathrm{FeOOH}$ ). It is interesting that $\mathrm{ZrO}_{2}$ was identified in the XRD results (Figure 4.2) but was not found during the SEM elemental analysis (Figure 4.4, Table 4.6). 


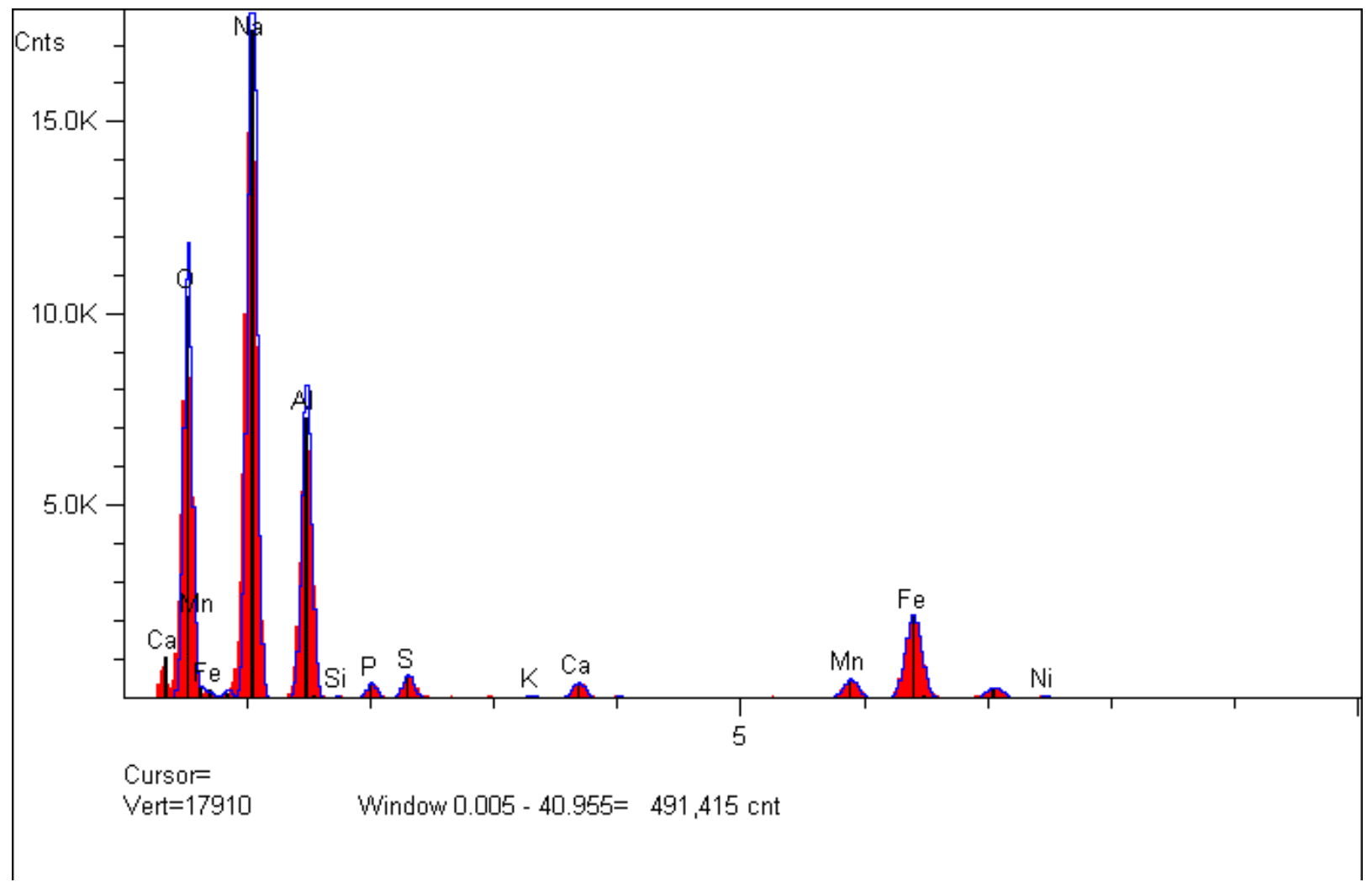

Figure 4.3. Simulant 2 SEM EDS Elemental Analysis with Peak Identification

Table 4.6. Simulant 2 SEM EDS Elemental Analysis with Peak Quantification

\begin{tabular}{ccrcrrl}
\hline Element & Line & $\begin{array}{c}\text { Intensity } \\
(\mathrm{cps})\end{array}$ & $\begin{array}{c}\text { Error } \\
\text { 2-sig }\end{array}$ & $\begin{array}{c}\text { Atomic } \\
\text { Percent }\end{array}$ & $\begin{array}{r}\text { Concentration } \\
\text { Percent }\end{array}$ & Units \\
\hline $\mathrm{O}$ & $\mathrm{Ka}$ & 1022.14 & 6.394 & 66.435 & 54.710 & $\mathrm{wt} \%$ \\
$\mathrm{Na}$ & $\mathrm{Ka}$ & 1881.34 & 8.675 & 24.774 & 29.316 & $\mathrm{wt} \%$ \\
$\mathrm{Al}$ & $\mathrm{Ka}$ & 812.50 & 5.701 & 5.676 & 7.882 & $\mathrm{wt} \%$ \\
$\mathrm{Si}$ & $\mathrm{Ka}$ & 5.31 & 0.461 & 0.032 & 0.046 & $\mathrm{wt} \%$ \\
$\mathrm{P}$ & $\mathrm{Ka}$ & 44.18 & 1.329 & 0.213 & 0.340 & $\mathrm{wt} \%$ \\
$\mathrm{~S}$ & $\mathrm{Ka}$ & 69.68 & 1.669 & 0.284 & 0.469 & $\mathrm{wt} \%$ \\
$\mathrm{~K}$ & $\mathrm{Ka}$ & 11.25 & 0.671 & 0.039 & 0.079 & $\mathrm{wt} \%$ \\
$\mathrm{Ca}$ & $\mathrm{Ka}$ & 54.94 & 1.482 & 0.194 & 0.400 & $\mathrm{wt} \%$ \\
$\mathrm{Mn}$ & $\mathrm{Ka}$ & 77.96 & 1.766 & 0.385 & 1.090 & $\mathrm{wt} \%$ \\
$\mathrm{Fe}$ & $\mathrm{Ka}$ & 342.22 & 3.700 & 1.898 & 5.457 & $\mathrm{wt} \%$ \\
$\mathrm{Ni}$ & $\mathrm{Ka}$ & 9.58 & 0.619 & 0.070 & 0.212 & $\mathrm{wt} \%$ \\
\hline & & & Total & 100.000 & 100.000 & $\mathrm{wt} \%$ \\
\hline
\end{tabular}




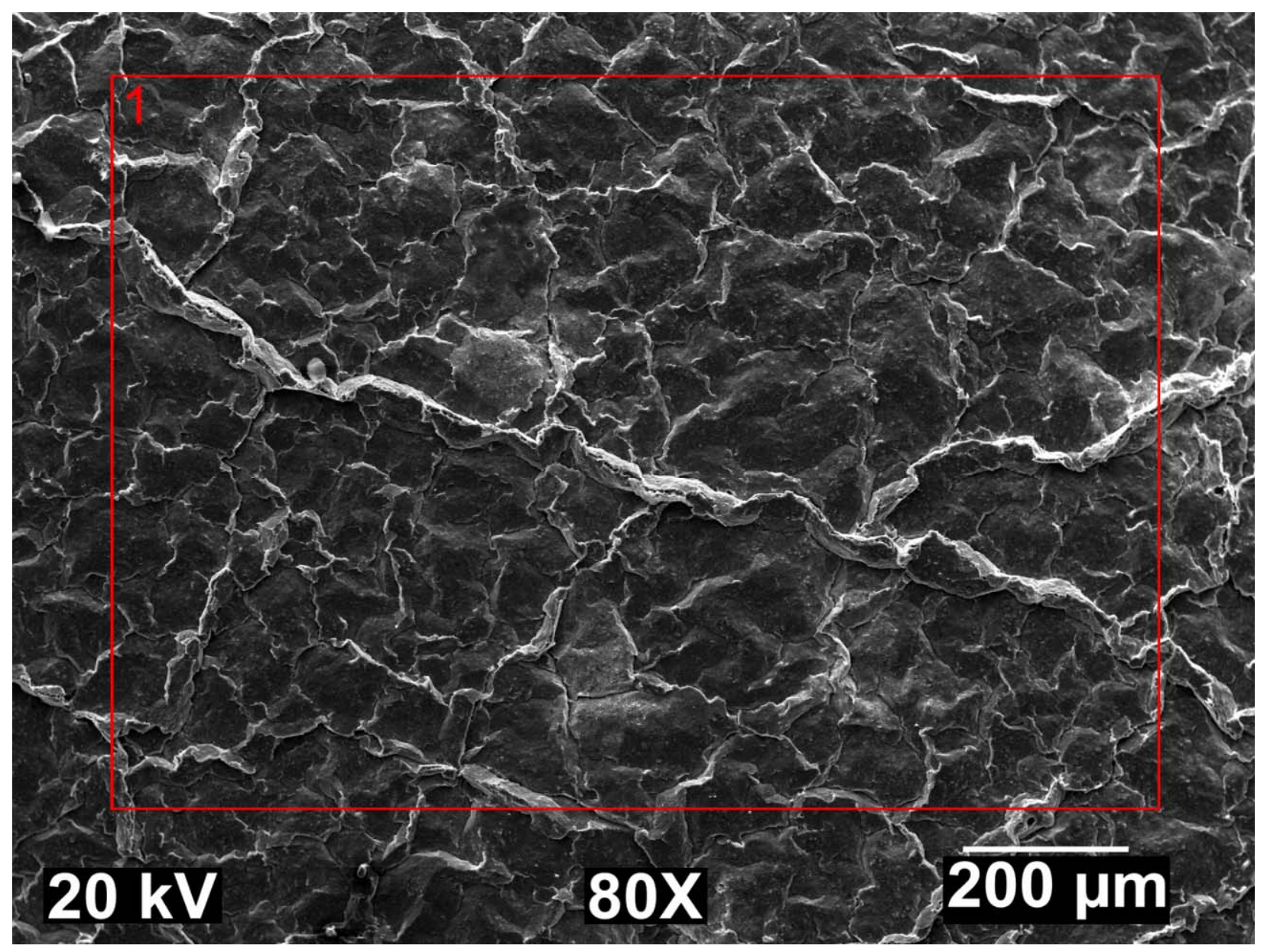

Figure 4.4. Location of SEM Elemental Analysis for Simulant 2

As presented in this section, there is a difference in the simulant compositions that mimics that of the Hanford sludge they are intended to represent. This difference is a beneficial outcome to the use of the simulants in follow-on work to experimentally measure lateral earth pressure at rest and shear modulus representative of Hanford sludge sediment (Section 1) because of the tank-to-tank breadth of compositions of Hanford sludge.

\subsection{Liquid Properties}

The simulant and Hanford waste liquid properties density, viscosity, and $\mathrm{pH}$ are provided in Table 4.7 (measured per Daniel 2007). The liquid viscosity reported for Simulant 1 is from Geeting et al. (2009). Liquid viscosity measurements for Simulant 2 were performed at laboratory temperature with an Anton Paar MCR301 rheometer using a concentric cylinder geometry according to procedure RPL-COLLOID02 (Daniel 2007). Flow curves were obtained by linearly increasing the shear rate from 0 to $1000 \mathrm{~s}^{-1}$ over 5 minutes. The shear rate was then held at $1000 \mathrm{~s}^{-1}$ for 1 minute, followed by a linear decrease in shear rate from 1000 to $0 \mathrm{~s}^{-1}$ over 5 minutes. The flow curve data plots are provided in Appendix D. The Simulant 2 viscosities reported in Table 4.7 are from the ramp down of shear rate from 0 to $200 \mathrm{~s}^{-1}$. There are no data specifically for the SST retrieval scenario basis for Simulant 2, so comparison is made to the bulk Hanford sludge. The Hanford sludge tank liquid values are typical or median values (Section 2). 
The simulant liquid properties compare reasonably well with the typical values of Hanford sludge tank liquids. The variation in liquid $\mathrm{pH}, 12.9$ to $>14$, spans the median Hanford sludge tank liquid $\mathrm{pH}$. Variation in $\mathrm{pH}$ has been shown to affect a material's shear strength (see Section 1 references). Thus, a range of $\mathrm{pH}$ is desirable for the simulants.

Table 4.7. Liquid Properties

\begin{tabular}{lccc}
\hline & $\begin{array}{c}\text { Density } \\
(\mathrm{g} / \mathrm{mL})\end{array}$ & $\begin{array}{c}\text { Viscosity } \\
(\mathrm{cP})\end{array}$ & $\mathrm{pH}$ \\
\hline Simulant 1 & 1.23 & 2.7 & $>14$ \\
Simulant 2 & 1.23 & 2.2 & 12.9 \\
Hanford Sludge Tanks & $1.1-1.2$ & $\sim 2$ & 13.2 \\
\hline
\end{tabular}

\subsection{Particle-Size Distribution}

PSD measurements were conducted on Simulants 1 and 2. The simulants were analyzed with a S3000 Microtrac Analyzer according to procedure TPR-RPP-WTP-222, Rev. 3 (Buchmiller 2006). No sonification was employed. The simulant and Hanford sludge volume-based PSD percentiles are provided in Table 4.8. The PSD data for Simulant 1, taken from Russell et al. (2009b), and that for Simulant 2 are provided in Appendix E.

There are no data specifically for the SST retrieval scenario basis for Simulant 2, so comparison is made to the bulk Hanford sludge. As indicated in Section 2.2, the PSD for Simulant 1 compares as favorably with the Hanford sludge PSD as the other simulants available for selection. Nominally $75 \%$ of the particulate by volume of Simulant 1 follows the Hanford sludge PSD reasonably well. Simulant 2 is shown to have larger particulate than Simulant 1 , and the $99^{\text {th }}$ percentile of Simulant 2 approximates the Hanford sludge. As with the solid-phase compositions of the simulants (Section 4.1), this PSD difference in the simulants is again a beneficial outcome to the use of the simulants in follow-on work to experimentally measure lateral earth pressure at rest and shear modulus representative of Hanford sludge sediment (Section 1) because of the PSD differences tank-to-tank in Hanford sludge (see Appendix A, Wells et al. 2007).

Table 4.8. Volume-Based PSD Percentiles $(\mu \mathrm{m})$

\begin{tabular}{lcccccccc}
\hline \multicolumn{1}{c}{ Percentiles } & $1 \%$ & $5 \%$ & $25 \%$ & $50 \%$ & $75 \%$ & $95 \%$ & $99 \%$ & $100 \%$ \\
\hline Simulant 1 $^{\text {(a) }}$ & 0.94 & 1.6 & 5.0 & 9.5 & 16 & 36 & 59 & 88 \\
Simulant 2 & 0.96 & 2.1 & 7.5 & 15 & 30 & 125 & 280 & 419 \\
Hanford & 0.65 & 1.0 & 2.8 & 6.3 & 14 & 59 & 256 & 1000 \\
Sludge $^{(b)}$ & & & & & & & & \\
\hline
\end{tabular}

(a) Russell et al. (2009b), Appendix A, Sample: PEP Feed 250 gallon Batch 7/28/08 DER.

(b) Wells et al. (2007), see also Section 2.1. 


\subsection{Rheology}

The rheology of the simulants is characterized by the Bingham yield stress and consistency, and the shear strength. The Bingham yield stress and consistency were obtained at laboratory temperatures with an Anton Paar MCR301 rheometer using a concentric cylinder geometry under procedure RPLCOLLOID-02 (Daniel 2007). The samples were fully mixed before being introduced into the rheometer. The rheometer was operated in the controlled-rate mode. Flow curves were obtained by linearly increasing the shear rate from 0 to $1000 \mathrm{~s}^{-1}$ over 5 minutes. The shear rate was then held at $1000 \mathrm{~s}^{-1}$ for 1 minute, followed by a linear decrease in shear rate from 1000 to $0 \mathrm{~s}^{-1}$ over 5 minutes. Higher UDS concentrations than the as-prepared (Section 4.1) were achieved via centrifugation (10 minutes at $4500 \mathrm{rpm}$ concentrated Simulant 2 from 0.23 to 0.35 mass fraction UDS).

The Bingham parameters from the shear rate down-curve are provided in Table 4.9 together with the mass fraction of UDS of the analyzed sample. Hanford slurry Bingham parameters at equivalent UDS concentrations are the approximate 95\% empirical limits provided in Section 2.1, Figure 2.7 and Figure 2.8. Both simulants exhibited thixotropic and, at the higher UDS concentrations, overshoot behavior as illustrated by the slurry flow curves in Appendix F. Thixotropic behavior is commonly observed in Hanford slurries (e.g., Poloski et al. 2007, Onishi et al. 2003). Overshoot behavior describes the elevated shear stress on the up-curve of the shear rate and will be discussed further in relation to the shear vane measurements presented below.

The lower UDS concentration simulant samples are shown to have Bingham parameters that fall within the 95\% empirical limits of the Hanford sludge slurry. The results for the higher UDS concentration simulant samples apparently exceed those of Hanford sludge slurry. However, as noted in Section 2.1, varied waste and sample conditions are represented in the Hanford data, and a trend of increased rheology with increased UDS concentration is expected (see references in Section 1 and the following shear strength discussion). Thus it is expected that the lower Bingham parameters for higher UDS concentrations shown in Figure 2.7 and Figure 2.8 for the Hanford waste are solely a result of the disparate data set. The increasing Bingham parameter trends up to 0.1 mass fraction UDS of Figure 2.7 and Figure 2.8 support the elevated simulant results.

The typical trend of increased simulant rheology with increased UDS concentration is shown in Figure 4.5. Also illustrated in Figure 4.5 is the difference in the simulants' Bingham parameters for a given UDS concentration. A range of simulant rheology at a given UDS concentration is desirable given the broad Hanford waste variation, Figure 2.7 and Figure 2.8.

The shear strength measurements were obtained using the vane method with a Haake M5 rheometer under procedure RPL-COLLOID-02 (Daniel 2007). Simulant shear-strength measurements are provided in Table 4.10 together with the mass fraction of UDS of the analyzed sample.

It has been shown for a given concentration that the shear strength of clay slurries and other cohesive materials can be a transient property that changes with the time the material remains quiescent. Poloski et al. (2007) summarizes shear strength as a function of quiescent or "gel" time for various gels, soils, chemical slurries, clay slurries, and actual pretreated Hanford waste, and shear strength is shown to increase with quiescent time to an eventual equilibrium shear strength. Equilibrium shear strengths are achieved after quiescent times from hours to weeks depending on the material considered. A clay slurry consisting of $80 \%$ kaolin, $20 \%$ bentonite by mass in water had a gel time of approximately 4 days. The 
shear strength of bentonite clay slurries, determined by varied methodologies, is shown as a function of quiescent time by Alderman et al. (1991) and Cheng (1986); an equilibrium shear strength is indicated to be reached in 4 to 5 days.

Shear-strength measurements on Simulants 1 and 2 were taken immediately after the sample was fully mobilized (0 hours), and, for some of the samples, subsequent increments of quiescent time, Table 4.10. Shear strength is shown to typically increase with time; no attempt was made in the current analysis to determine the time to a steady-state value.

Table 4.9. Bingham Rheological Parameters

\begin{tabular}{|c|c|c|c|}
\hline Material & Mass Fraction UDS & $\begin{array}{c}\text { Bingham Yield Stress } \\
(\mathrm{Pa})\end{array}$ & $\begin{array}{c}\text { Bingham Consistency } \\
\text { (cP) }\end{array}$ \\
\hline Simulant $1^{\text {(a) }}$ & 0.06 & 0 & 4.7 \\
\hline Hanford Sludge Slurry & 0.06 & $0.004-2$ & $1.8-4$ \\
\hline Simulant $1^{(\mathrm{b})}$ & 0.31 & 30 & 26 \\
\hline Hanford Sludge Slurry & 0.31 & $0.3-14$ & $2-10$ \\
\hline Simulant $1^{(b, c)}$ & 0.40 & 16 & 76 \\
\hline Hanford Sludge Slurry & 0.40 & $0.9-8$ & $2.8-10$ \\
\hline Simulant $2^{(\mathrm{b})}$ & 0.23 & 6.5 & 15 \\
\hline Hanford Sludge Slurry & 0.23 & $0.2-20$ & $0.9-10.5$ \\
\hline Simulant $2^{(b)}$ & 0.35 & 185 & 69 \\
\hline Hanford Sludge Slurry & 0.35 & $0.6-9$ & $2-10.2$ \\
\hline $\begin{array}{l}\text { (a) Geeting et al. (2009) } \\
\text { (b) Current analysis. } \\
\text { (c) Average of two meas }\end{array}$ & nts, see Appendix F. & & \\
\hline
\end{tabular}

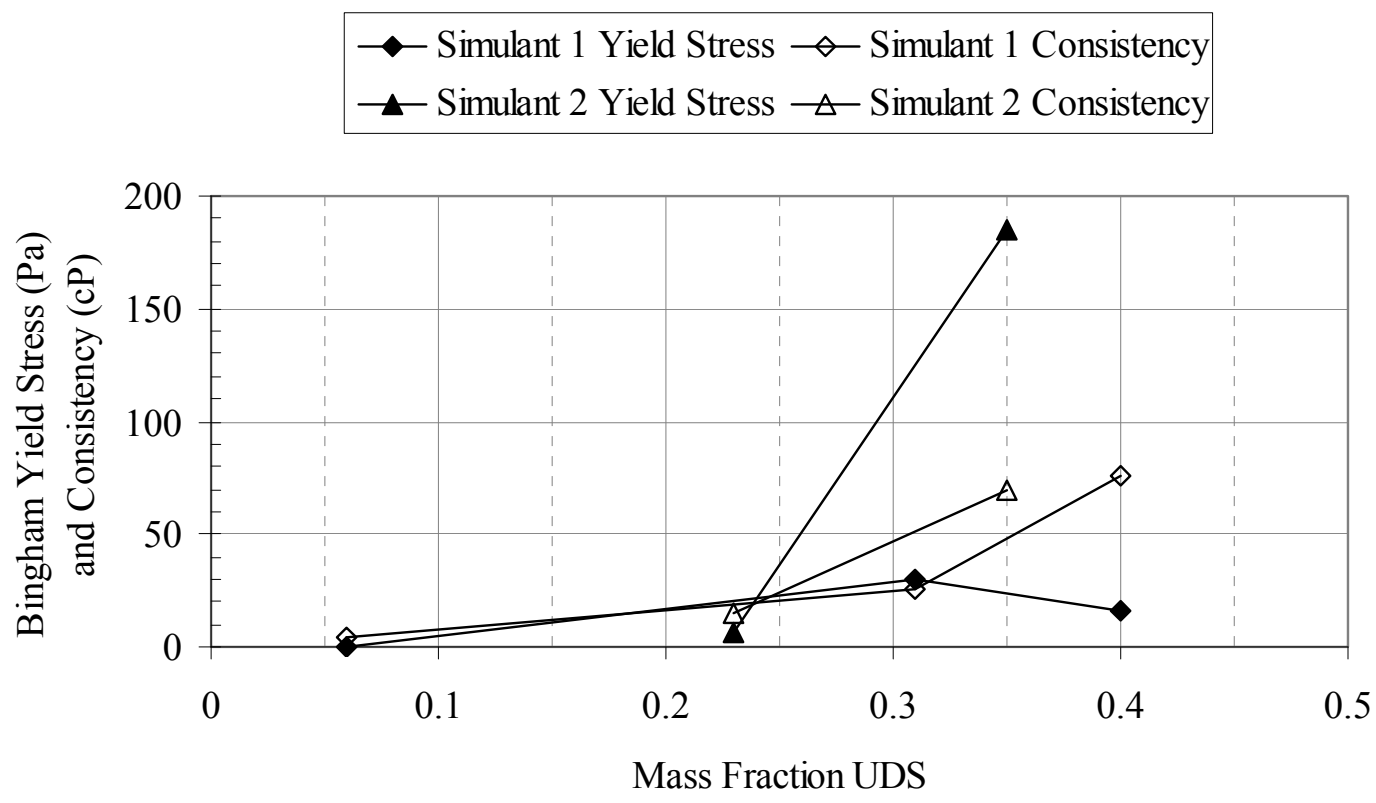

Figure 4.5. Simulant Bingham Parameters as Functions of Mass Fraction UDS. Lines are for data clarity only; an exponential relation may be expected (Poloski et al. 2007). 
Table 4.10. Shear Strength

\begin{tabular}{lcc}
\hline Material & Mass Fraction UDS & Shear Strength (Pa), Quiescent Time \\
\hline Simulant 1 & 0.31 & $34.3,0$ hours \\
Hanford Sludge Slurry & 0.31 & $160-6000,<50$ years \\
Simulant 1 & 0.40 & 921,0 hours \\
& & 1088,1 hour \\
& & 1383,24 hours \\
Hanford Sludge Slurry & 0.40 & $70-9000,<50$ years \\
\hline Simulant 2 & 0.23 & $8.7,0$ hours \\
& & $21.6,24$ hours \\
Hanford Sludge Slurry & 0.23 & $300-3100,<50$ years \\
Simulant 2 & 0.35 & 775,0 hours \\
& & 752,1 hour \\
Hanford Sludge Slurry & 0.35 & 1133,24 hours \\
\hline
\end{tabular}

The Hanford sludge sediment shear strengths at equivalent UDS concentrations provided in Table 4.10 are the approximate 95\% empirical limits provided in Section 2.1, Figure 2.11. Even with the significant quiescent time differences, the simulants fall within the broad shear-strength range of the Hanford sludge sediment. As with the Bingham rheological parameters, varied waste and sample conditions are represented by the Hanford data.

The trend of increased shear strength with increased UDS concentration for the simulants is shown in Figure 4.6 for the 0 -hours measurements. Actual waste shear-strength and UDS-concentration relations for T-204, B-203, and AZ-101 from Gauglitz et al. (2009) are included.

Numerous experimental studies related to the storage and retrieval of waste from the large underground Hanford storage tanks have employed clay slurries as simulants to represent the waste of interest. These studies have included investigations of gas retention and release (Gauglitz et al. 1994, Gauglitz et al. 1995, Gauglitz et al. 1996, Stewart et al. 1996, etc.), sediment mobilization (Powell et al. 1995, Enderlin et al. 2003, Bontha et al. 2005, Kurath et al. 2007, etc.), and slurry transport (Poloski et al. 2009). Gauglitz and Aiken (1997) developed a method to obtain shear-strength estimates for Hanford sediment via visual observation of waste core extrusion behavior. To do so, they employed bentonite slurry to mimic ductile waste behavior and Kaolin/Ludox slurry to mimic brittle waste behavior. The correlations for kaolin and kaolin/bentonite from (Rassat et al. 2003) are presented in Figure 4.2 together with bentonite data (16 hour quiescent time) from Alderman et al (1991).

Simulants 1 and 2 are shown to have slopes (note log plot) like the B-203 and T-204 data and are bounded by the previously employed clay simulants. The shear strength-UDS mass fraction relation for Simulant 1 is

$$
\tau=0.0004 \mathrm{e}^{36.559 \mathrm{w}_{\mathrm{S}}}
$$

and 


$$
\tau=0.0016 \mathrm{e}^{37.413 \mathrm{w}_{\mathrm{s}}}
$$

for Simulant 2. As noted in regards to Table 4.8, the simulants reasonably reproduce expected Hanford sludge sediment shear strengths.

The Bingham yield stress and shear strength at constant sample conditions can be compared. It is noted that the Bingham yield stress does not necessarily represent the value of the yield stress in shear as an intrinsic, instrument-geometry indifferent, rheological property of a slurry, while the shear strength (i.e., the yield stress in shear measured with a shear vane) is a direct measurement (Turian et al. 2002, Nguyen and Boger 1983, Nguyen and Boger 1992, Barnes 1999).

The Bingham yield stress and shear strength of pretreated Hanford sludge waste is compared in Poloski et al. (2004), and the shear strength is shown to be larger by about a factor of three. Gauglitz et al. (2009) reported comparisons for Hanford sludge waste. The ratio of shear strength to Bingham yield stress for diluted B-203 and T-203 waste is 5 and 8, respectively (Tingey et al. 2003). A ratio approaching 1000 may be determined from core-sample analyses of AZ-101 waste (Urie et al. 2002). (a) The overshoot behavior of the higher UDS concentration simulant rheograms (as referenced above) affects this ratio. Overshoot behavior has been observed for Hanford sludge slurries (Tingey et al. 2003).

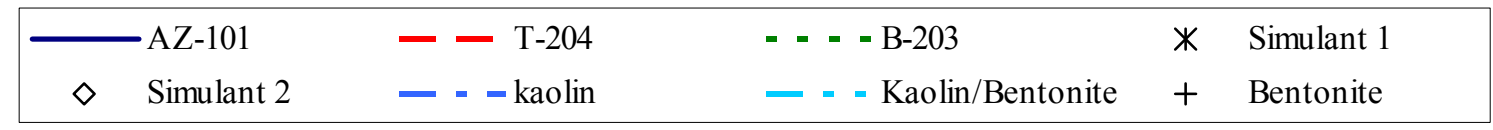

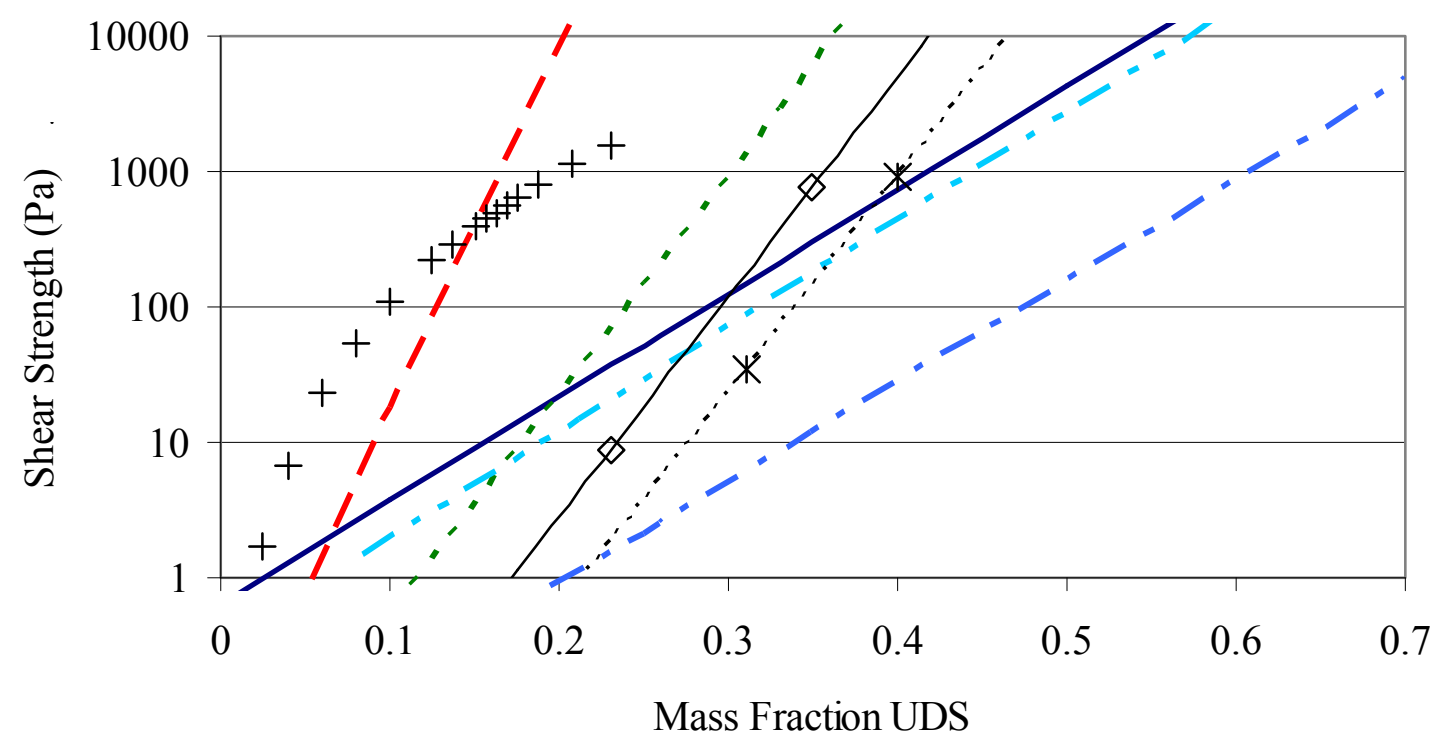

Figure 4.6. Shear Strength as a Function of UDS Concentration

(a) Memorandum from DB Bechtold to KE Bell, RA Esch, and FH Steen. Correction of Shear Strength Measurements Reported by 222S Laboratory. March 28, 2001. 8D500-DBB-01-018, Fluor Hanford, Richland, Washington. 
Speers et al. (1987) refer to "gel strength" as "the shear strength overshoot which occurs in a previously resting fluid which is suddenly sheared." For the current analysis, the simulant material was completely mobilized immediately before being introduced into the rheometer, and the measurements were immediately taken once the sample was in the rheometer. Baudez (2006) concluded that the initial stress overshoot is highly dependent on the shear-rate increment profile and the data sampling.

The Bingham yield stress (low UDS concentrations) or approximate peak shear stress (high UDS concentrations) from the simulant ramp-up flow curves of Appendix F is provided in Table 4.11 together with the Bingham yield stress and shear strength at 0 hours from Table 4.9 and Table 4.10, respectively. Good agreement (Bingham yield stress to shear strength ratio is $\sim 1$ ) is shown for the lower UDS concentration conditions. These comparisons potentially show that at the lower UDS concentrations, the simulants behave as a Bingham plastic as both the indirect and direct measures of the yield stress in shear are in close agreement.

The peak shear stress (flow curve ramp-up) is shown to compare much more favorably with the shear strength than the Bingham yield stress (flow curve ramp-down) for the higher UDS concentrations. The rheogram peak shear-stress to shear-strength ratios for Simulants 1 and 2 are in remarkable agreement at 1.25 and 1.35, respectively. This comparison may suggest that the overshoot behavior from the rheograms is not solely an artifact of the indirect measurement method.

The different rheological behavior (i.e., Table 4.9 through Table 4.11) of the simulants is appropriate given the differences of Hanford sludge and the use of these simulants in follow-on work to experimentally measure lateral earth pressure at rest and shear modulus representative of Hanford sludge sediment (see Section 1).

Table 4.11. Bingham Yield Stress and Shear-Strength Comparison

\begin{tabular}{lcccc}
\hline \multicolumn{1}{c}{ Material } & Mass Fraction UDS & $\begin{array}{c}\text { Bingham Yield } \\
\text { Stress }(\mathrm{Pa})\end{array}$ & $\begin{array}{c}\text { Ramp-up Shear } \\
\text { Stress (Pa) }\end{array}$ & $\begin{array}{c}\text { Shear Strength } \\
(\mathrm{Pa})\end{array}$ \\
\hline Simulant 1 & 0.31 & 30 & 31.5 & 34.3 \\
Simulant 1 & 0.40 & $16^{(\mathrm{b})}$ & $735^{(\mathrm{b})}$ & 921 \\
\hline Simulant 2 & 0.23 & 6.5 & 7.4 & 8.7 \\
Simulant 2 & 0.35 & 185 & 575 & 775 \\
\hline (a) Approximate values from flow curve ramp-ups, Appendix F. Simulant 1 and 2 low UDS concentrations, \\
Bingham yield stress, Simulant 1 and 2 high UDS concentrations, peak shear stress. \\
(b) Average of two measurements, see Appendix F.
\end{tabular}

\subsection{Shear Modulus}

The shear modulus is the slope of the initial linear portion of a shear stress-shear strain curve and is a measure of the material's stiffness in shear. Alderman et al. (1991) provide an extension of the vane technique to determine the shear modulus, $\mathrm{G}$, as 


$$
\mathrm{G}=\frac{1}{4 \pi \omega \mathrm{H}}\left(\frac{\mathrm{dT}}{\mathrm{dt}}\right)\left(\frac{1}{\mathrm{R}^{2}}-\frac{1}{\mathrm{R}_{\mathrm{C}}^{2}}\right)
$$

where $\quad \omega=$ angular velocity of the vane

$$
\mathrm{H}=\text { vane height }
$$

$\mathrm{dT} / \mathrm{dt}=$ slope of the linear portion of the torque-time curve resulting from the Hookean elastic response of the sample

$\mathrm{R}=$ vane radius

$\mathrm{R}_{\mathrm{C}} \quad$ radius of the sample container.

Alderman et al. demonstrated good agreement between the shear modulus determined via the vane technique and Equation (4.4) and low-strain oscillation measurements using a Bohlin VOR rheometer in a $9.99 \mathrm{wt} \%$ bentonite clay suspension.

Equation (4.4) is applied to the shear-vane measurement data of Table 4.10. In addition to the vane dimension and placement in sample requirements synonymous with RPL-COLLOID-02 (Daniel 2007), Equation (4.4) requires that the vane be placed near the center of the sample container radially, and the container diameter should be about three times larger than the vane diameter. These conditions were met in the current analysis. The vane rotational speed was 0.03 revolutions per second for all measurements, a 1.6- $\mathrm{cm} \times 1.6-\mathrm{cm}$ (diameter $\times$ height) vane was used for the lower UDS concentration samples, and a $0.6-\mathrm{cm} \times 0.6-\mathrm{cm}$ vane for the higher UDS concentration samples. Simulant 1 was measured in a 5-cmdiameter container, and Simulant 2 was in a 5 -cm-diameter container for the lower UDS concentration measurements, $6 \mathrm{~cm}$ for the higher.

The shear modulus is shown to increase (Simulant 1, 1 hour to 24 hours does not follow trend) with both the UDS concentration and quiescent time as expected (Alderman et al. 1991), Table 4.12.

Comparison of shear strength and shear modulus as functions of the UDS concentration is made in Figure 4.7. As noted in Section 1, there are no in situ shear modulus data for the Hanford sediment. Thus, the bentonite clay shear strength (see Figure 4.6) and shear modulus of Alderman et al. (1991) are used for comparison.

The simulant data presented in Figure 4.7 are for the 0 hours measurements, and the bentonite clay data are from the fit to 16-hour quiescent time measurements. At a given UDS concentration, the shear modulus for the simulants is shown to exceed the shear strength by a factor of approximately 2 or greater. The shear modulus of the bentonite clay increasingly exceeds the shear strength starting at UDS mass fractions greater than approximately 0.1 . 
Table 4.12. Shear Modulus

\begin{tabular}{lcc}
\hline Material & Mass Fraction UDS & Shear Modulus (Pa), Quiescent Time \\
\hline Simulant 1 & 0.31 & 74,0 hours \\
Simulant 1 & 0.40 & 5737,0 hours \\
& & 8193,1 hour \\
& & 7771,24 hours \\
\hline Simulant 2 & 0.23 & 39,0 hours \\
& & 84,24 hours \\
Simulant 2 & 0.35 & 1925,0 hours \\
& & 2492,1 hour \\
& & 4574,24 hours \\
\hline
\end{tabular}

* Simulant 1 Shear Strength $\diamond$ Simulant 2 Shear Strength + Bentonite Shear Strength

Simulant 1 Shear Modulus $\diamond$ Simulant 2 Shear Modulus $\times$ Bentonite Shear Modulus

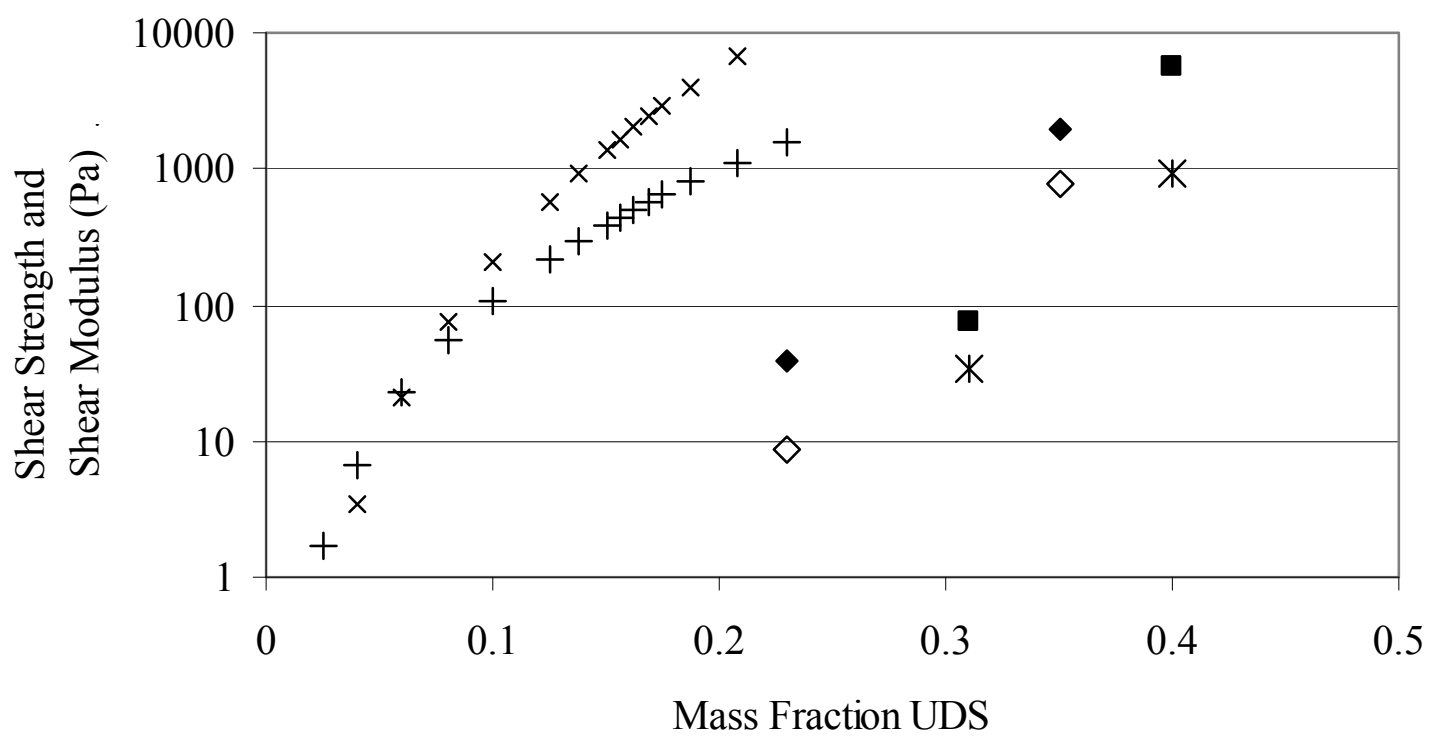

Figure 4.7. Shear Strength and Shear Modulus as a Function of UDS Concentration. Bentonite Shear Strength and Shear Modulus from (Alderman et al. 1991).

\subsection{Settling}

As discussed in Section 2, gravity settling of the UDS particulate of the simulants is of interest in comparison to actual waste behavior. Settling tests were conducted with PEP simulant by Russell et al. (2009b). Data from this test, representing Simulant 1, and settling data for Simulant 2, conducted as per Russell et al. (2009b), are presented in Figure 4.8. The bulk UDS mass fraction for each simulant was nominally 0.04 , and the simulants were well mixed at the commencement of the tests. The testing was performed in 50-mL centrifuge tubes, and the solid-to-liquid interface height was measured as a function of time. 
The simulants are shown to settle similarly, Figure 4.8. Settling is essentially completed at 24 hours for Simulant 1, and Simulant 2 appears to continue to be compacted at 72 hours. The settling rate from approximately 45 minutes into the settling test to 2 hours (corresponding to the period of fastest settling) is approximately $5.8 \mathrm{E}-6 \mathrm{~m} / \mathrm{s}$ for Simulant 1 and $4.2 \mathrm{E}-6 \mathrm{~m} / \mathrm{s}$ for Simulant 2.

\section{$\diamond$ Simulant $1 \square$ Simulant 2}

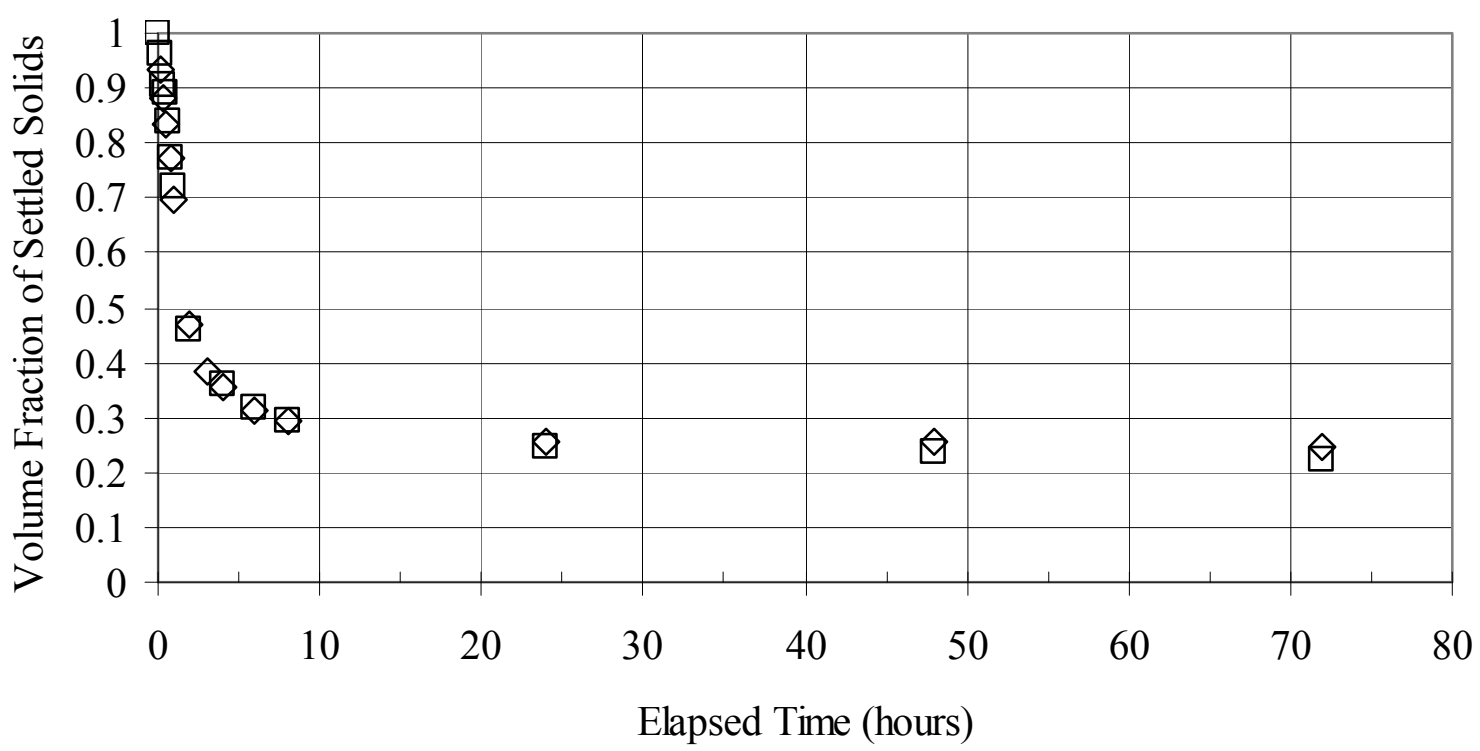

Figure 4.8. Simulant Settling Test Results

In situ solid-to-liquid interface settling-rate data are available from two Hanford sludge tanks, AZ101 and AY-102. The initial conditions of the vessels for the settling rate determinations are different (mixer pump operation in AZ-101 [Carlson et al. 2001], and slurry transfer from C-106 in AY-102 [Cuta et al. 2000]) and the settling data are from different measurement and evaluation techniques. Fully-mixed conditions in AZ-101 result in a UDS mass fraction of approximately 0.03 , and the actual UDS concentration of the mixed layer was approximately 0.01 (Wells and Ressler 2009). For AY-102, a fully mixed condition results in a UDS fraction of approximately 0.06 (Wells and Ressler 2009), but actual settling conditions had much lower concentrations due to the batch-wise retrieval (Cuta et al. 2000). The in situ solid-to-liquid interface settling rates from the respective documents are $6 \mathrm{E}-4 \mathrm{~m} / \mathrm{s}$ for AZ-101 and $5 \mathrm{E}-5$ to $6 \mathrm{E}-6 \mathrm{~m} / \mathrm{s}$ for AY-102. Laboratory-scale solid-to-liquid interface settling data for waste samples from these tanks indicate maximum settling rates of 2.8E-5 m/s for AZ-101 (Callaway 2000) and 4.2E-6 $\mathrm{m} / \mathrm{s}$ for AY-102 (Warrant 2001). This discrepancy in settling rate between in situ and laboratory scale is referenced in Section 2. The Simulant 1 and 2 settling rate data are similar to the laboratory-scale settling rate data for AY-102 and thus under-represent the in situ measured settling rates.

As done by Gauglitz et al. (2009), the UDS concentration in the settled layer can be computed, and, if a uniform distribution of UDS concentration with depth is assumed in the settled layer, the shear strength of that layer can be estimated. Applying Equations (4.2) and (4.3) to the settling data of Figure 4.8 yields the shear strength with time for the settled layers shown in Figure 4.9. In the laboratory-scale settling test, Simulant 1 is shown to reach a calculated shear strength of approximately $0.15 \mathrm{~Pa}$ (UDS mass fraction 0.16 ), and Simulant 2 has a calculated shear strength of approximately $0.8 \mathrm{~Pa}$ (UDS mass fraction 
0.17). In addition to increased compaction with time, the shear strength-mass fraction relations of Equations (4.1) and (4.2) are based on the 0 hours shear-strength measurements, so the 72-hour calculated shear strengths may be treated as a lower bound.

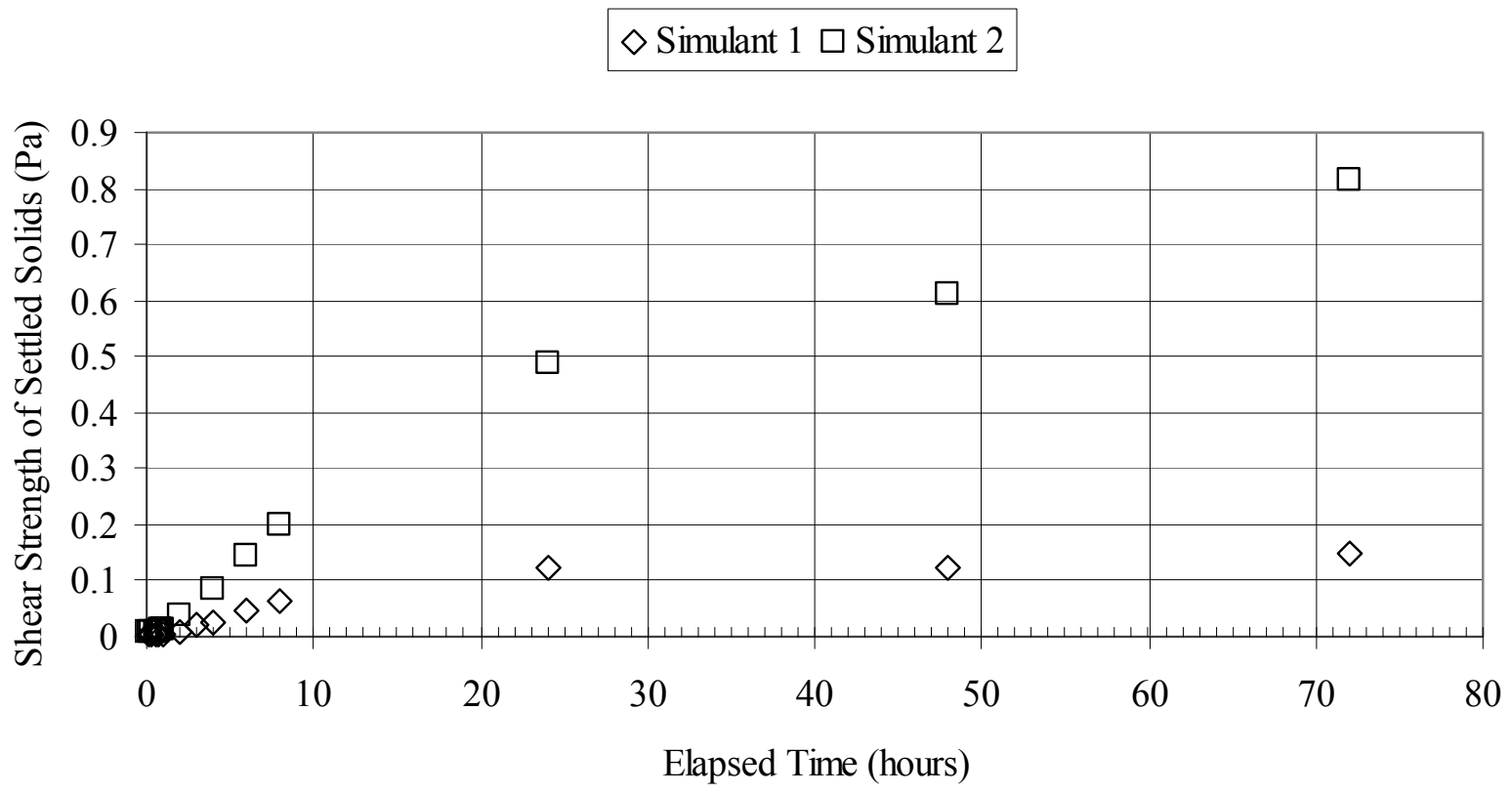

Figure 4.9. Calculated Simulant Settled Layer Shear Strength as a Function of Settling Time, Settling Data from Figure 4.3

\subsection{Particulate Imaging}

SEM was used to qualitatively illustrate the UDS particulate of the simulants. SEM micrographs representing Simulant 1 are provided in Figure 4.10. The primary UDS phase compounds are gibbsite $\left(\mathrm{Al}[\mathrm{OH}]_{3}\right)$, boehmite $(\mathrm{AlOOH})$, and $\mathrm{Fe}(\mathrm{OH})_{3}$, Section 4.1 .

Qualitative comparison to actual Hanford waste SEM micrographs taken from Wells et al. (2007) of aluminum and iron phases shows similar variation in size and shape. Figure 4.11 through Figure 4.13 show gibbsite, boehmite, and $\mathrm{Fe}_{2} \mathrm{O}_{3}$, respectively, from different Hanford tanks. The magnification of these images relative to those of Figure 4.10 can be approximated by assuming the constituents are of similar size and observing the size bars. 


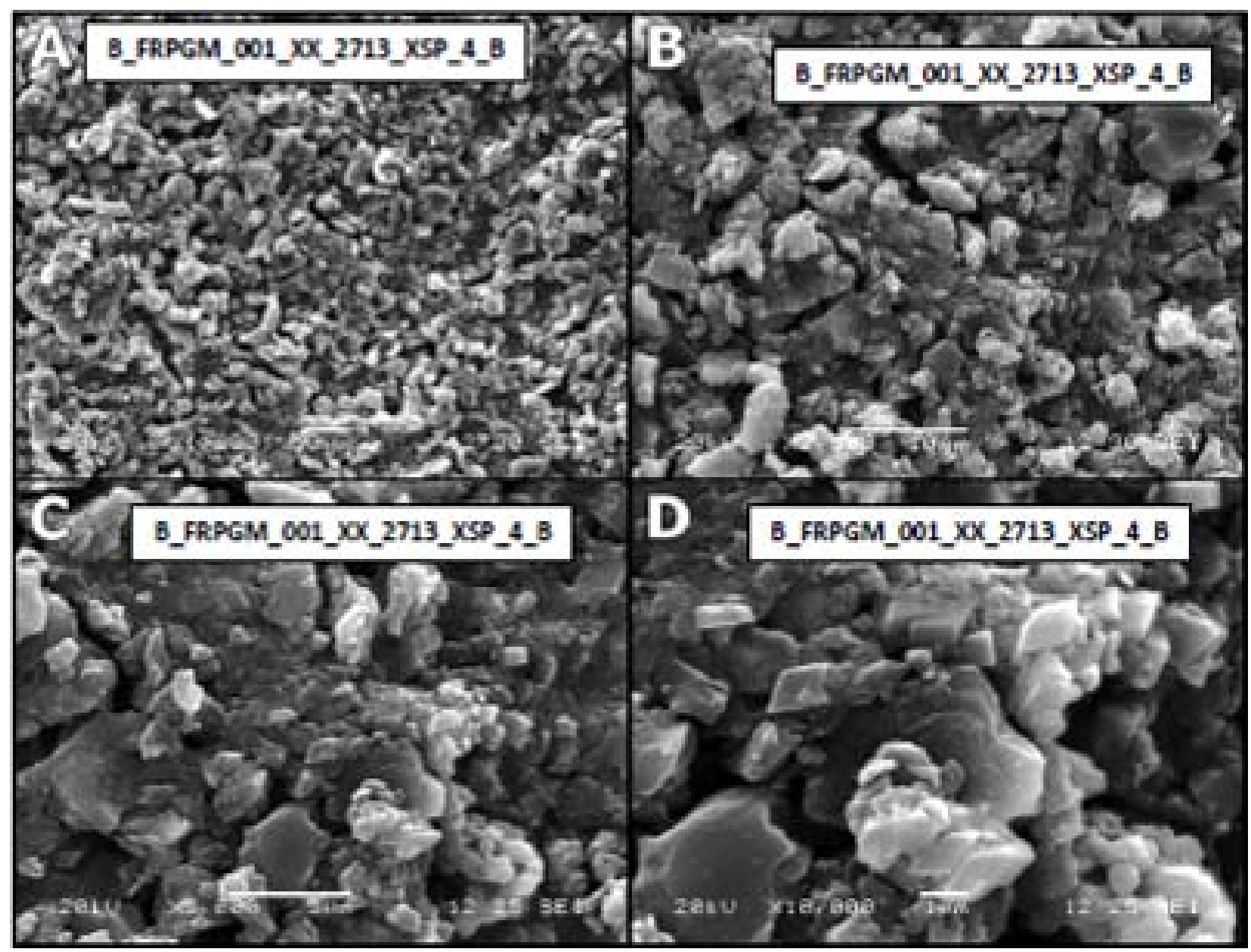

Figure 4.10. SEM Micrographs, Simulant 1 (Geeting et al. 2009). Magnification-A: 1,000×, B: $2,500 \times$ C: $5,000 \times$, and D: $10,000 \times$. 


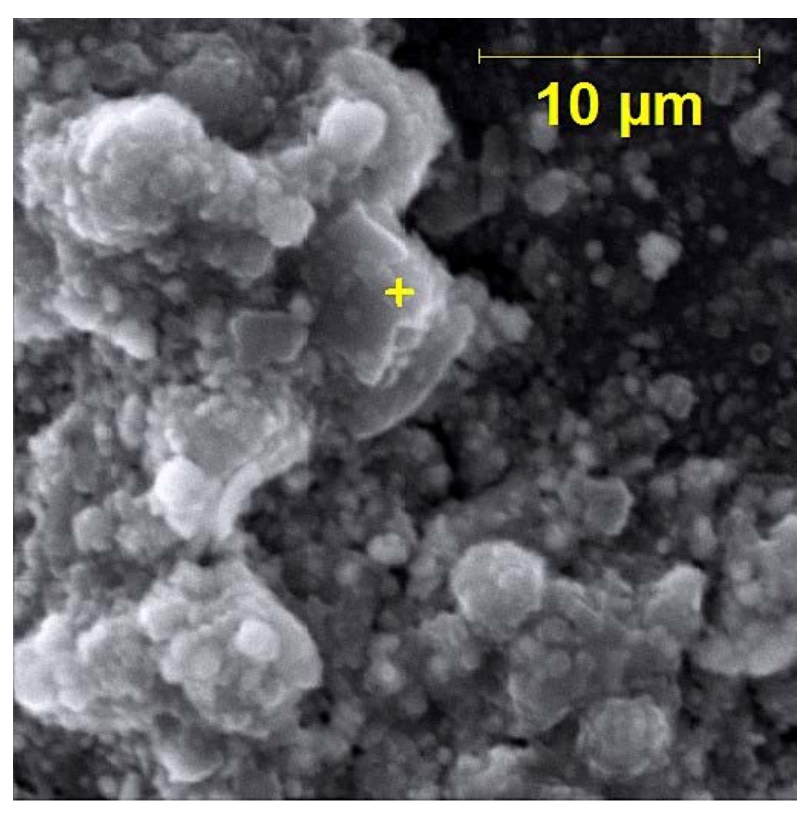

a)

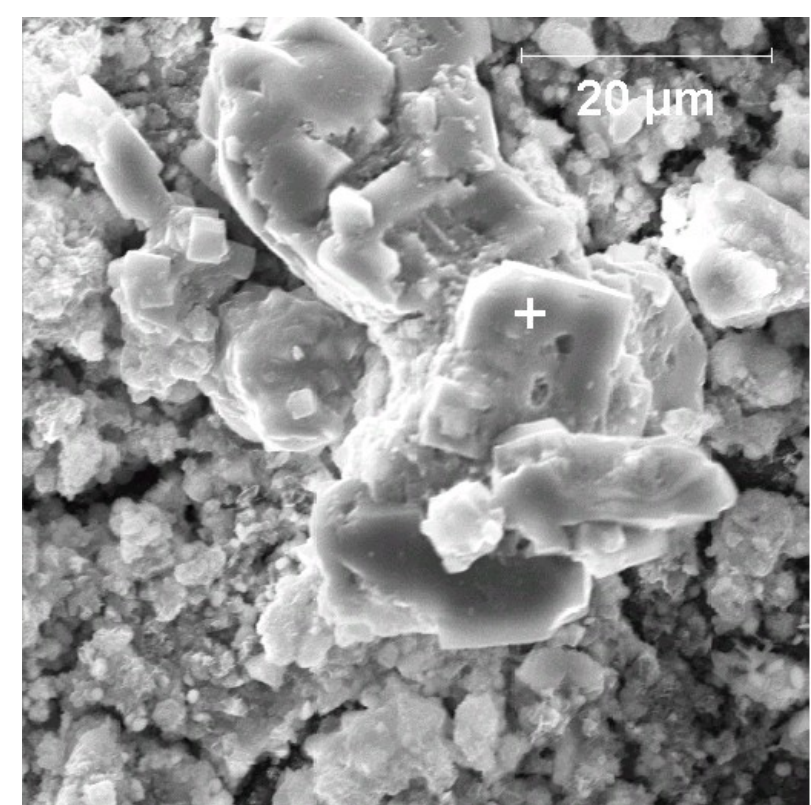

b)

Figure 4.11. a) Gibbsite $/ \mathrm{Al}(\mathrm{OH})_{3}$ from Tank $\mathrm{AY}-102,{ }^{(\mathrm{a})}$ b) Gibbsite $/ \mathrm{Al}(\mathrm{OH})_{3}$ from Tank $\mathrm{AZ}-102$ (Warrant 2002)

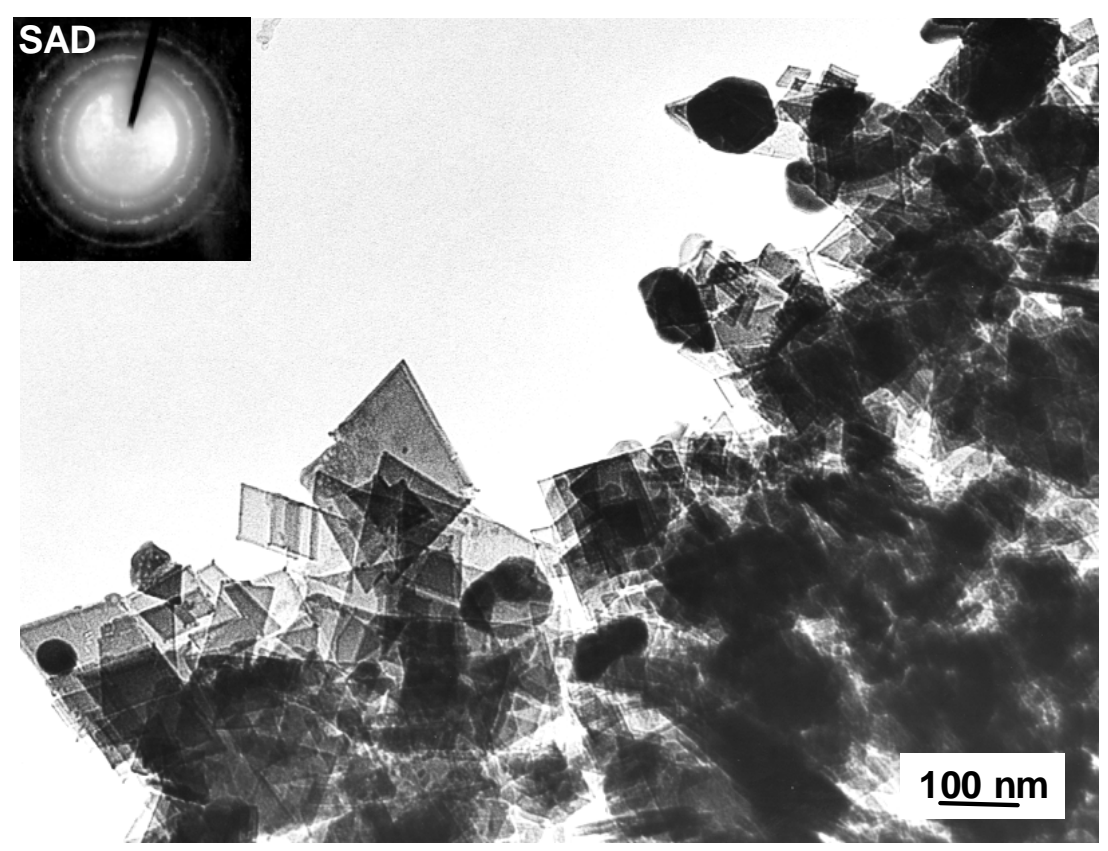

Figure 4.12. Boehmite/AlOOH Particles from Tank S-104 (Lumetta et al. 1997)

(a) RW Warrant. "Results of Caustic Testing of Tank 241-AY-102 Core 319 Sludge Solids." 7S110-RWW-06080, November 2006, CH2M HILL Hanford Group Inc., Richland, Washington. 


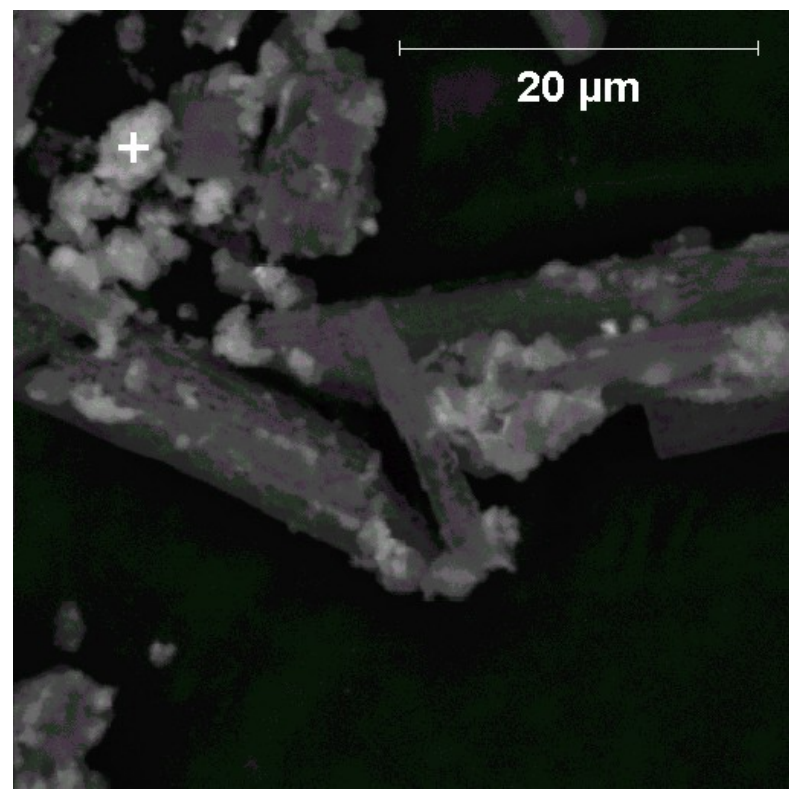

a)

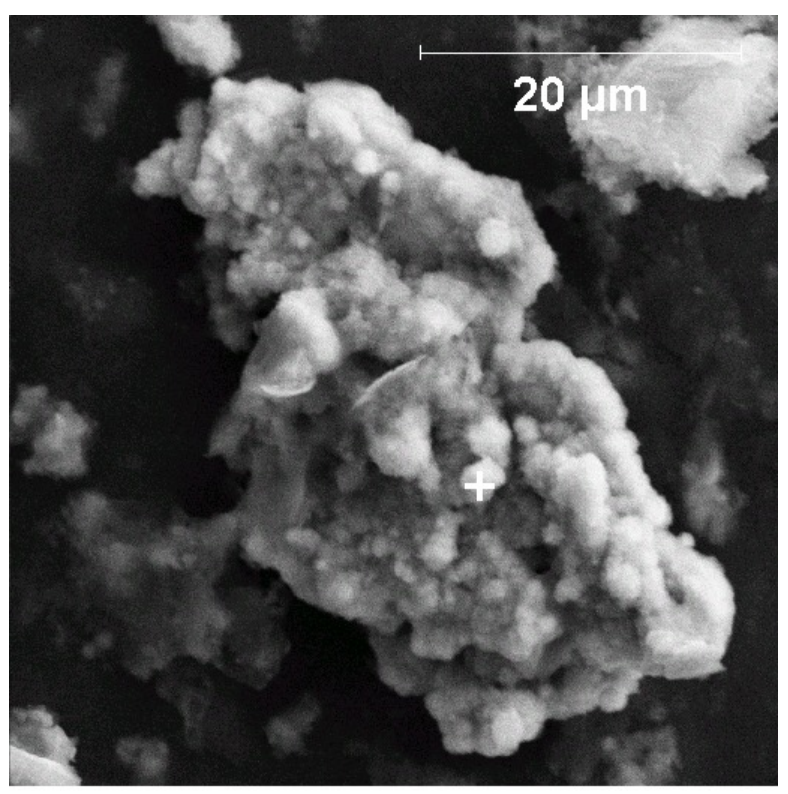

b)

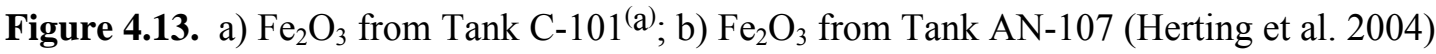

SEM micrographs representing Simulant 2 are provided in Figure 4.14. The primary UDS phase compounds are gibbsite $\left(\mathrm{Al}[\mathrm{OH}]_{3}\right), \mathrm{ZrO}_{2}$, and $\mathrm{FeOOH}$, Section 4.1. An SEM micrograph for large $\mathrm{ZrO}_{2}$ particulate from actual Hanford waste taken from Wells et al. (2007) is provided in Figure 4.15. As for Simulant 1, qualitatively comparative size and shape variation is observable between Figure 4.14 and Figure 4.11, Figure 4.13, and Figure 4.15.

(a) Frye JM. "Results of Caustic Testing of 241-C-101 \& 241-C-107." 7S110-JMF-05-015, 4/29/2005, CH2M HILL Hanford Group Inc., Richland, Washington. 


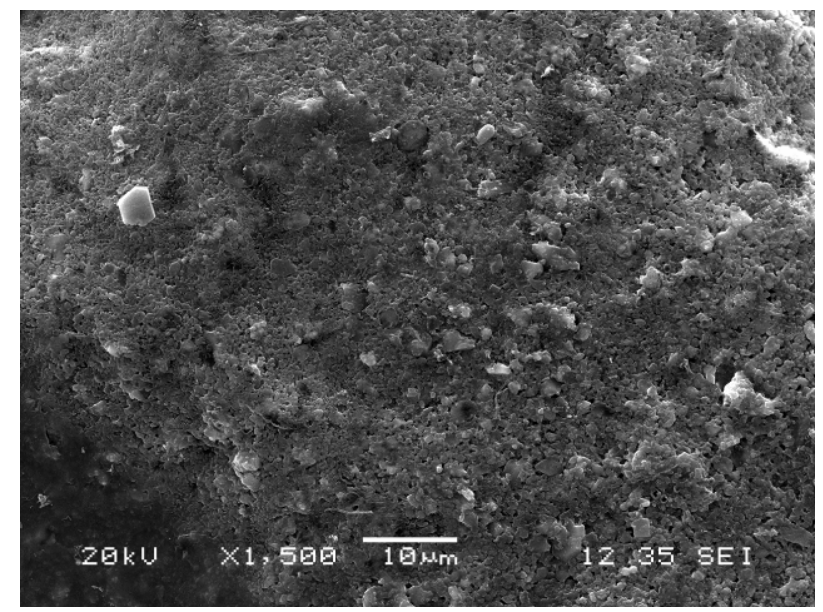

a)

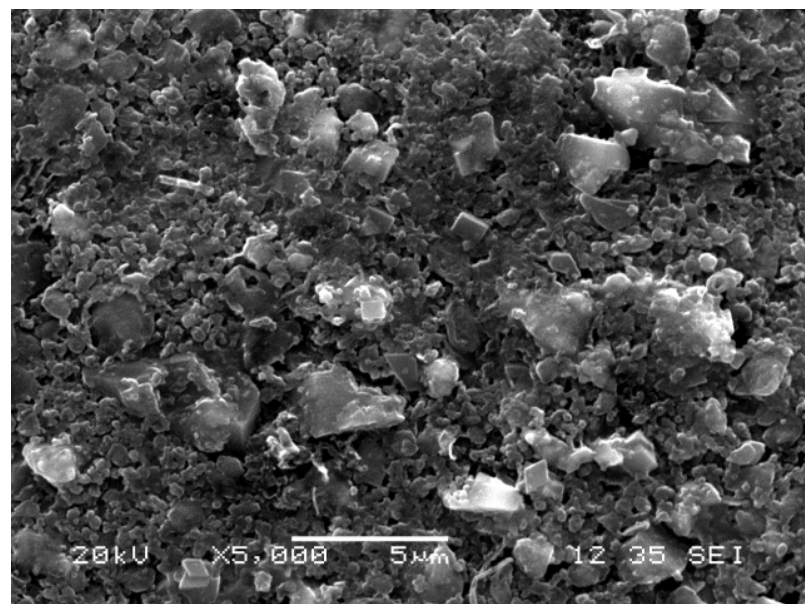

b)

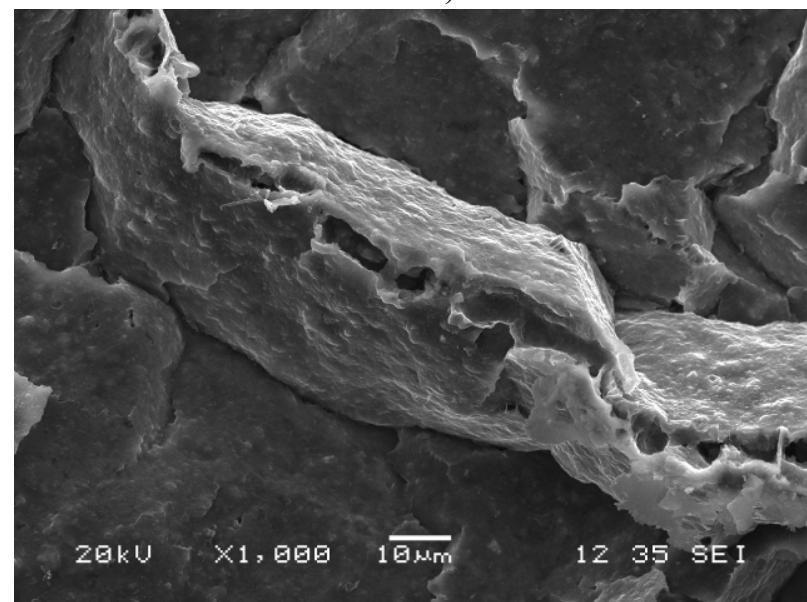

c)

Figure 4.14. SEM Micrographs, Simulant 2; a) Location 1, Magnification 1500×, b) Location 1, Magnification 5000×, c) Location 2, Magnification 1000× 


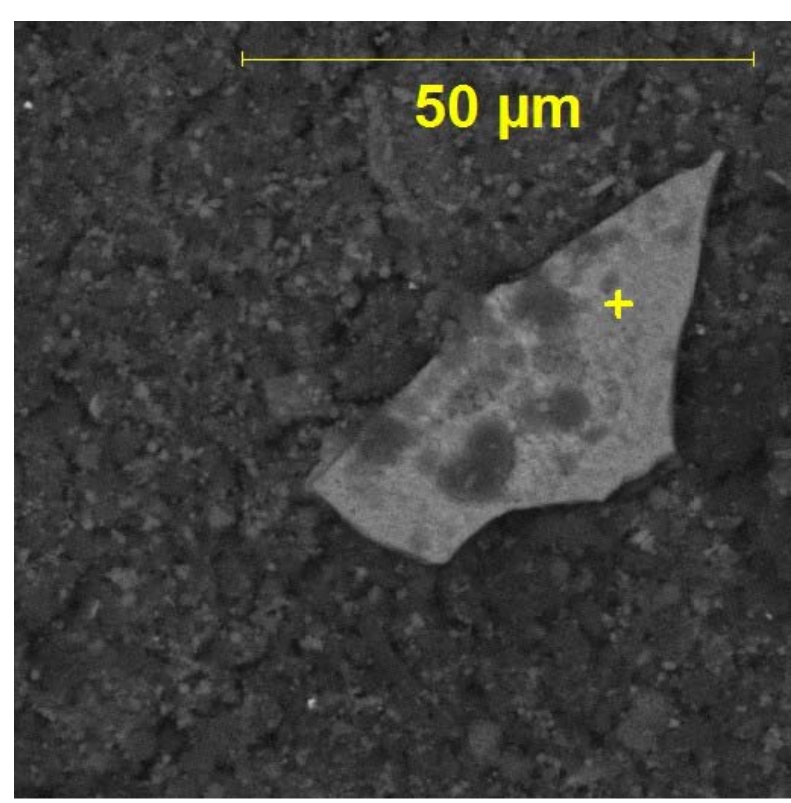

a)

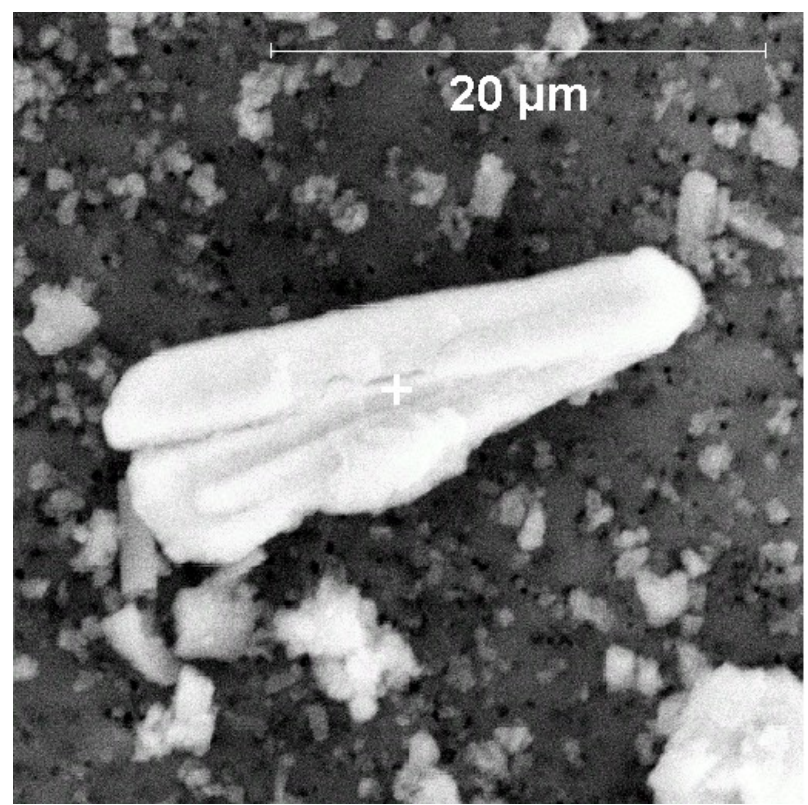

b)

Figure 4.15. a) $\mathrm{ZrO}_{2}$ from Tank $\mathrm{AY}-102^{(\mathrm{a})}$; b) $\mathrm{ZrO}_{2}$, from Tank $\mathrm{SY}-102^{(\mathrm{b})}$

(a) Warrant RW. "Results of Caustic Testing of Tank 241-AY-102 Core 319 Sludge Solids." 7S110-RWW-06080, November 2006, CH2M HILL Hanford Group Inc., Richland, Washington.

(b) Callaway WS and GA Cooke. "Distribution of Plutonium-Rich Particles in Tank 241-SY-102 Sludge." CH2M-0400872, 5/17/2004, CH2M HILL Hanford Group, Inc., Richland, Washington. 


\subsection{Summary}

The objective of this work was to select or develop two chemical sludge simulants to be used in follow-on work to experimentally measure lateral earth pressure at rest and shear modulus representative of Hanford sludge sediment. Two chemical simulants, one representing the Hanford sludge as a whole and the other a specific SST retrieval scenario (C-104, C-111, and C-112 retrieval into AN-101) have been selected to meet this objective.

Simulant 1 is chosen from Hanford sludge simulants that have previously been produced and characterized. The selection is based on comparison to actual Hanford sludge chemical and physical properties. Simulant 2 is developed based upon the chemistry of the specific SST retrieval scenario.

The sludge parameters to be measured in follow-on work, lateral earth pressure at rest, and shear modulus are expected to be influenced by the chemical and physical properties of the sludge material. Simulants 1 and 2 are shown to have chemical and physical properties that match well with all of the Hanford sludge parameters considered. The uniqueness of the simulants with respect to each other for some of the parameters considered is a beneficial outcome given the broad variation of Hanford waste. 



\subsection{References}

Alderman NJ, GH Meeten, and JD Sherwood. 1991. "Vane Rheometry of Bentonite Gels." Journal of Non-Newtonian Fluid Mechanics 39:291-310.

Ancey C and H Jorrot. 2001. "Yield Stress for Particle Suspensions Within a Clay Dispersion.” Journal of Rheology 45(2):297-319.

Barnes HA and QD Nguyen. 2001. "Rotating Vane Rheometry - A Review." Journal of Non-Newtonian Fluid Mechanics 989:1-14.

Barnes HA. 1999. "The Yield Stress-A Review or ' $\pi \alpha \nu \tau \alpha \rho \varepsilon \imath$-Everything Flows?” Journal of NonNewtonian Fluid Mechanics 81: 133-178.

Baudez J-C. 2006. “About Peak and Loop in Sludge Rheograms.” Journal of Environmental Management 78:232-239.

Bontha JR, GR Golcar, and N Hammigan. 2000. Demonstration and Optimization of BNFL's Pulsed Jet Mixing and RFD Sampling Systems Performance Using NCAW Simulant. PNWD-3054 (BNFL-RPT-048 Rev. 0), Battelle-Pacific Northwest Division, Richland, Washington.

Bontha JR, TE Michener, DS Trent, JM Bates, and MD Johnson. 2003. Development and Assessment of the TEMPEST CFD Model of the Pulsed Jet Mixing Systems. PNWD-3261 (WTP-RPT-061 Rev. 0), Battelle-Pacific Northwest Division, Richland, Washington.

Bontha JR, CW Stewart, DE Kurath, PA Meyer, ST Arm, CE Guzman-Leong, MS Fountain, M Friedrich, SA Hartley, LK Jagoda, CD Johnson, KS Koschik, DL Lessor, F Nigl, RL Russell, GL Smith, W Yantasee, and ST Yokuda. 2005. Technical Basis for Predicting Mixing and Flammable Gas Behavior in the Ultrafiltration Feed Process and High-Level Waste Lag Storage Vessels with NonNewtonian Slurries. PNWD-3676 (WTP-RPT-132, Rev. 0), Pacific Northwest National Laboratory, Richland, Washington.

Buchmiller WC. 2006. S3000 Microtrac Particle Size Analyzer. TPR-RPP-WTP-222, Rev. 3, Pacific Northwest National Laboratory, Richland, Washington.

Buscall R, IJ McGowan, PDA Mills, RF Stewart, D Sutton, LR White, and GE Yates. 1987. "The Rheology of Strongly Flocculated Suspensions." Journal of Non-Newtonian Fluid Mechanics 24:183-202.

Callaway WS. 2000. Results of Retrieval Testing of Sludge from Tank 241-AZ-101. HNF-7078, Rev. 0, Fluor Hanford, Richland, Washington.

Carlson AB, PJ Certa, TM Hohl, JR Bellomy III, TW Crawford, DC Hedengren, AM Templeton, HS Fisher, SJ Greenwood, DG Douglas, and WJ Ulbright Jr. 2001. Test Report, 241-AZ-101 Mixer Pump Test. RPP-6548, Rev. 1, Numatec Hanford Corporation, Richland, Washington. 
Certa PJ and MN Wells. 2009. River Protection Project System Plan. ORP-11242 Rev. 4. Office of River Protection, Richland, Washington.

Channell GM and CF Zukoski. 1997. "Shear and Compressive Rheology of Aggregated Alumina Suspensions." AIChE Journal 43(7):1700-1708.

Cheng D C-H. 1986. "Yield Stress: A Time Dependent Property and How to Measure It." Rheological Acta 25:542-554.

Cowley WL, JL Huckaby, LA Mahoney, GR Golcar, KM Krupka, DS Sklarew, and DJ Geniesse. 2003. Chemical Source Terms for Tank Farms Safety Analyses. RPP-8369 Rev. 2, CH2M HILL Hanford Group, Inc., Richland, Washington.

Craig RF. 2004. “Craig's Soil Mechanics.” ISBN 0-415-32702-4. Spon Press, New York, New York.

Cuta JM, KG Carothers, DW Damschen, WL Kuhn, JA Lechelt, K Sathyanarayana, and LA Stauffer. 2000. Review of Waste Retrieval Sluicing System Operations and Data for Tanks 241-C-016 and 241$A Y$-102. PNNL-13319, Pacific Northwest National Laboratory, Richland, Washington.

Daniel RC. 2007. PNNL Technical Procedure, "Measurement of Physical and Rheological Properties of Solutions, Slurries and Sludges." RPL-COLLOID-02 Rev. 1, Pacific Northwest National Laboratory, Richland, Washington.

Enderlin CW, G Terrones, CJ Bates, BK Hatchell, B Adkins. 2003. Recommendations for Advanced Design Mixer Pump Operation in Savannah River Site Tank 18F. PNNL-14443, Pacific Northwest National Laboratory, Richland, Washington.

Gauglitz PA, and JT Aikin. 1997. Waste Behavior During Horizontal Extrusion: Effect of Waste Strength for Bentonite and Kaolin/Ludox Simulants and Strength Estimates for Wastes from Hanford Tanks 241-SY-103, AW-101, AN-103, and S-102. PNNL-11706, Pacific Northwest National Laboratory, Richland, Washington.

Gauglitz PA, LA Mahoney, DP Mendoza, and MC Miller. 1994. Mechanisms of Gas Bubble Retention. PNL-10120, Pacific Northwest Laboratory, Richland, Washington.

Gauglitz PA, RR Shah, SD Rassat, LA Mahoney, and MR Powell. 1995. Gas Bubble Retention and Its Effects on Waste Properties: Retention Mechanisms, Viscosity, and Tensile and Shear Strengths. PNL10740, Pacific Northwest Laboratory, Richland, Washington.

Gauglitz PA, SD Rassat, PR Bredt, JH Konynenbelt, SM Tingey, and DP Mendoza. 1996. Mechanisms of Gas Bubble Retention and Release: Results for Hanford Waste Tanks 241 S 102 and 241 SY 103 and Single Shell Tank Simulants. PNNL 11298, Pacific Northwest National Laboratory, Richland, Washington.

Gauglitz PA, BE Wells, JA Fort, and PA Meyer. 2009. An Approach to Understanding Cohesive Slurry Settling, Mobilization, and Hydrogen Gas Retention in Pulsed Jet Mixed Vessels. PNNL-17707, WTPRPT-177, Rev. 0, Pacific Northwest National Laboratory, Richland, Washington. 
Geeting JGH, EC Golovich, DE Kurath, OP Bredt, CE Guzman-Leong, GJ Sevigny, CA Burns, GB Josephson, and RL Aaberg. 2009. Pretreatment Engineering Platform (PEP) Integrated Test B Run Report - Caustic and Oxidative Leaching in UFP-VSL-T02A. PNNL-18723, WTP-RPT-192, Rev. 0, Pacific Northwest National Laboratory, Richland, Washington.

Gephart RE and RE Lundgren. 2005. Hanford Tank Cleanup: A guide to Understanding the Technical Issues. PNL-10773. Pacific Northwest Laboratory, Richland, Washington.

Golcar GR, KP Brooks, JG Darab, JM Davis, and LK Jagoda. 2000. Development of Inactive High Level Waste Envelope D Simulants for Sealed Crossflow Filtration Testing. PNWD-3042, BNFL-RPT-033 Rev. 0, Battelle-Pacific Northwest Division, Richland, Washington.

Hansen EK, RE Eibling, and TB Calloway, Jr. 2001. Mixing Envelope D Sludge with LAW Intermediate Products with and without Glass Formers. WSRC-TR-2001-00203, Rev. 0, SRT-RPP-2001-00051, Rev. 0. Westinghouse Savannah River Company, Aiken, South Carolina.

Hedengren DC, KM Hodgson, WB Barton, CW Stewart, JM Cuta, and BE Wells. 2000. Data Observations on Double-Shell Flammable Gas Watch List Tank Behavior. RPP-6655, CH2MHILL Hanford Group, Inc., Richland, Washington.

Herting DL, GA Cooke, and RW Warrant. 2004. Hanford Tank 241-AN-107 Solid Phase Characterization. RPP-20018, CH2M HILL Hanford Group, Inc., Richland, Washington.

Jaky J. 1948. "Pressure in Soils." In: The Second International Conference on Soil Mechanics and Foundation Engineering, London, Vol. 1, 103-107.

Kurath DE, PA Meyer, JR Bontha, AP Poloski, JA Fort, WH Combs, WC Buchmiller, ID Welch, and MD Bleich. 2007. Assessment of Pulse Tube Mixing for Vessels Containing Non-Newtonian Slurries. PNWD-3827 (WTP-RPT-155, Rev. 0), Pacific Northwest National Laboratory, Richland, Washington.

Kurath DE, PW Eslinger, SM Barnes, RL Aaberg, BD Hanson, JL Huckaby, EC Golovich, PM Aker, MJ Minette, JM Billing, SD Rassat, CE Guzman-Leong, DL Baldwin, PS Sundar, CF Brown, ML Kimura, BM Rapko, GJ Josephson, JGH Geeting, SK Sundaram, LA Mahoney, JJ Toth, GJ Sevigny, RP Pires, PP Schonewill, ST Yokuda, AJ Casella, BE Wells, RC Daniel, EBK Baer, JR Bontha, and OP Bredt. 2009. Pretreatment Engineering Platform Phase 1 Final Test Report. PNNL-18894, WTP-RPT-197 Rev. 0, Pacific Northwest National Laboratory, Richland, Washington.

Lumetta GJ, IE Burgeson, MJ Wagner, J Liu, and YL Chen. 1997. Washing and Caustic Leaching of Hanford Tank Sludge: Results of FY1997 Studies. PNNL-11636, Pacific Northwest National Laboratory, Richland, Washington.

Meyer PA and CW Stewart. 2001. Preventing Buoyant Displacement Gas Release Events in Hanford Double-Shell Waste Tanks. PNNL-13337, Pacific Northwest National Laboratory, Richland, Washington. 
Meyer PA, JA Bamberger, CW Enderlin, JA Fort, BE Wells, SK Sundaram, PA Scott, MJ Minette, GL Smith, CA Burns, MS Greenwood, GP Morgen, EBK Baer, SF Snyder, M White, GF Piepel, BG Amidan, A Heredia-Langner. 2009. Pulse Jet Mixing tests with Noncohesive Solids. PNNL-18098, WTP-RPT182, Rev. 0, Pacific Northwest National Laboratory, Richland, Washington.

Naeini SA and MH Baziar. 2004. "Effect of Fines Content on Steady-State Strength of Mixed and Layered Samples of Sand.” Soil Dynamics and Earthquake Engineering 24:181-187.

Nquyen QD and DV Boger. 1983. "Yield Stress Measurement for Concentrated Suspensions." Journal of Rheology 27(4):321-349.

Nguyen QD and DV Boger. 1992. "Measuring the Flow Properties of Yield Stress Fluids.” Annual Review of Fluid Mechanics 24:47-88.

Onishi Y, BE Wells, ST Yokuda, and G Terrones. 2003. Feasibility Study on Using a Single Mixer Pump for Tank 241-AN-101 Waste Retrieval. PNNL-14105, Pacific Northwest National Laboratory, Richland, Washington.

Poloski AP, PA Meyer, LK Jagoda, and PR Hrma. 2004. Non-Newtonian Slurry Development and Selection for Pulse Jet Mixer Testing. PNWD-3495, WTP-RPT-111, Rev. 0, Battelle_Pacific Northwest Division, Richland, Washington.

Poloski AP, JM Tingey, BE Wells, LA Mahoney, MN Hall, GL Smith, SL Thomson, ME Johnson, MA Knight, JE Meacham, MJ Thien, JJ Davis, and Y Onishi. 2007. Estimate of Hanford Waste Rheology and Settling Behavior. PNNL-16857, WTP-RPT-154, Rev. 0, Pacific Northwest National Laboratory, Richland, Washington.

Poloski AP, ML Bonebrake, AM Casella, MD Johnson, JJ Toth, HE Adkins, Jr, J Chun, KM Denslow, M Luna, and JM Tingey. 2009. Deposition Velocities of Non-Newtonian Slurries in Pipelines: Complex Simulant Testing. PNNL-18316, WTP-RPT-189 Rev. 0, Pacific Northwest National Laboratory, Richland, Washington.

Powell MR, CM Gates, CR Hymas, MA Sprecher, and NJ Morter. 1995. Fiscal Year $19941 / 25^{\text {th }}$-Scale Sludge Mobilization Testing. PNL-10582, Pacific Northwest National Laboratory, Richland, Washington.

Rassat SD, LM Bagaasen, LA Mahoney, RL Russell, DD Caldwell, and DP Mendoza. 2003. Physical and Liquid Chemical Simulant Formulations for Transuranic Wastes in Hanford Single-Shell Tanks. PNNL-14333, Pacific Northwest National Laboratory, Richland, Washington.

Russell RL, DE Rinehart, JM Billing, HD Smith, and RA Peterson. 2009a. Development and Demonstration of Ultrafiltration Simulants. PNNL-18090, WTP-RPT-183, Rev. 0, Pacific Northwest National Laboratory, Richland, Washington.

Russell RL, RA Peterson, WC Buchmiller, DE Rinehart, and KJ Cantrell. 2009b. Results of Aging Tests of Vendor-Produced Blended Feed Simulant. WTP-RPT-198, Rev. 0, Pacific Northwest National Laboratory, Richland, Washington. 
Russell RL, DE Rinehart, RA Peterson, PM Aker, HD Smith, and EC Buck. 2009c. Development and Characterization of Boehmite Component Simulant. PNNL-18176 Rev. 1, WTP-RPT-184, Rev. 1, Pacific Northwest National Laboratory, Richland, Washington.

Schatzmann M, P Ficher, and GR Bezzola. 2003. "Rheological Behavior of Fine and Large Particle Suspensions." Journal of Hydraulic Engineering, ASCE Vol. 129, No. 10:796-803.

Scheele RD, GN Brown, and DE Kurath. 2009. Scale-up, Production, and Procurement of PEP Simulant. PNNL-18678, WTP-RPT-204, Rev. 0, Pacific Northwest National Laboratory, Richland, Washington.

Smith HD, RL Russell, and RA Peterson. 2009. Simulated Waste for Leaching and Filtration StudiesLaboratory Preparation Procedure. PNNL-18701, WTP-RPT-201, Rev. 0, Pacific Northwest National Laboratory, Richland, Washington.

Spears RA, KR Holme, MA Tung, and WT Williamson. 1987. "Drilling Fluid Shear Stress Overshoot Behavior." Rheologica Acta 26:447-452.

Stewart CW, LA Mahoney, CE Guzman-Leong, JM Alzheimer, ST Arm, JA Bailey, MG Butcher, SK Cooley, EC Golovich, DE Hurley, LK Jagoda, CD Johnson, WR Park, LD Reid, RW Slaugh, HD Smith, Y Su, BE Wells, C Wend, and ST Yokuda. 2007. Results from Large-Scale Testing on Effects of AntiFoam Agent on Gas Retention and Release. WTP-RPT-156 Rev 0, Pacific Northwest National Laboratory, Richland, Washington.

Stewart CW, PA Meyer, ME Brewster, KP Recknagle, PA Gauglitz, HC Reid, and LA Mahoney. 1996. Gas Retention and Release Behavior in Hanford Single-Shell Waste Tanks. PNNL-11391, Pacific Northwest National Laboratory, Richland, Washington.

Tingey JM, J Gao, LM Bagaasen, and BE Wells. 2003. Physical Property and Rheological Testing of Actual Transuranic Waste from Hanford Single-Shell Tanks. ST03.016, Pacific Northwest National Laboratory, Richland, Washington.

Turian RM, JF Attal, DJ Sung, and LE Wedgewood. 2002. "Properties and Rheology of Coal-Water Mixtures Using Different Coals." Fuel 81:2019-2033.

Urie MW, GM Mong, PR Bredt, AP Poloski, JA Campbell, RD Scheele, OT Farmer, CZ Soderquist, SK Fiskum, RG Swoboda, LR Greenwood, MP Thomas, EW Hoppe, JJ Wagner, and LK Jagoda. 2002. Chemical Analysis and Physical Property Testing of 241-AZ-101-Tank Waste-Supernatant and Centrifuged Solids. PNWD-3215, Rev 1 (WTP-RPT-048, Rev 1), Pacific Northwest National Laboratory, Richland, Washington.

van Kessel T and WGM van Kesteren. 2002. "Gas Production and Transport in Artificial Sludge Depots." Waste Management 22:19-28.

Warrant RW. 2001. Results of Retrieval Testing of Sludge from Tank 241-AY-102. RPP-8909 Rev. 0, Fluor Hanford Inc., Richland, Washington.

Warrant RW. 2002. Results of Retrieval Testing of Sludge from Tank 241-AZ-102. RPP-9806 Rev. 0, Fluor Hanford Inc., Richland, Washington. 
Weber RA. 2008. Methodology and Calculations for the Assignment of Waste Groups for the Large Underground Waste Storage Tanks at the Hanford Site. RPP-10006, Rev. 8, CH2M HILL Hanford Group, Inc., Richland, Washington.

Wells BE and JJ Ressler. 2009. Estimate of the Distribution of Solids Within Mixed Hanford DoubleShell Tank AZ-101: Implications for AY-102. PNNL-18327, Pacific Northwest National Laboratory, Richland, Washington.

Wells BE, JM Cuta, SA Hartley, LA Mahoney, PA Meyer, and CW Stewart. 2002. Analysis of Induced Gas Releases During Retrieval of Hanford Double-Shell Tank Waste. PNNL-13782, Pacific Northwest National Laboratory, Richland, Washington.

Wells BE, MA Knight, EC Buck, SK Cooley, RC Daniel, LA Mahoney, PA Meyer, AP Poloski, JM Tingey, WS Callaway III, GA Cooke, ME Johnson, MG Thien, DJ Washenfelder, JJ Davis, MN Hall, GL Smith, SL Thomson, and Y Onishi. 2007. Estimate of Hanford Waste Insoluble Solid Particle Size and Density Distribution. PNWD-3824, WTP-RPT-153, Rev. 0, Battelle-Pacific Northwest Division, Richland, Washington.

Zamecnik JR, PR Burket, RE Eibling, and MR Poirier. 2004. Tank 241-AY-102 Simulant Development, Ultrafiltration, and Washing. WSRC-TR-2003-00547, Rev. 0, SRT-RPP-2003-00240, Rev. 0, Westinghouse Savannah River Company, Aiken, South Carolina.

Zhou Z, MJ Solomon, PJ Scales, and DV Boger. 1999. "The Yield Stress of Concentrated Flocculated Suspensions of Size Distributed Particles.” Journal of Rheology 43(3):651-671. 
Appendix A

Recipe for Simulant 1 Iron-Bearing and Supernatant Simulant Component Preparation 



\section{Appendix A: Recipe for Simulant 1 Iron-Bearing and Supernatant Simulant Component Preparation}

The following is a step-by-step recipe for preparing the filtration simulant component of the simulant described in this report, and it was chosen to be used in the Pretreatment Engineering Platform (PEP) testing. This is the recipe that was used by Pacific Northwest National Laboratory (PNNL) and a vendor to prepare the simulant (Russell et al. 2009). Note: The component make up procedures (A.1, A.2, and A.3) are for a specified target volume (A.1 and A.2) or weight UDS (A.3), so multiples of the target values are generally made up when the wt\% UDS and volume of the simulant batch are known.

\section{A.1-PREPARATION OF SIMPLE SUPERNATE}

This preparation is for a "simple" version of the supernate simulant that is used for the initial washes of the precipitated sludge solids. This simple simulant contains the most abundant species found in the supernate simulant, but does not contain the minor species. Perform at ambient temperature unless indicated otherwise.

Note: $\leq \pm 0.5 \%$ is sufficient accuracy on masses.

The following recipe should be carried out in a plastic or stainless steel vessel. No glass shall be used. All additions are based on mass.

Note: The target volume is $1 \mathrm{~L}$.

Tare weight of 2-L vessel:

1- Add to the 2-L vessel:

\begin{tabular}{cccc}
\hline & Mass Needed $(\mathrm{g})$ & Actual Mass $(\mathrm{g})$ & Resistivity of water \\
\hline Water (deionized, DI) & $\sim 200.0$ & & \\
\hline
\end{tabular}

2 Add:

\begin{tabular}{cccc}
\hline Compounds & Formula & Target Mass (g) & Actual Mass (g) \\
\hline Sodium Sulfate & $\mathrm{Na}_{2} \mathrm{SO}_{4}$ & $2.67 \pm 0.013$ & \\
\hline
\end{tabular}

3 In separate 10-L container, mix the following:

\begin{tabular}{llcc}
\hline Compounds & Formula & Target Mass (g) & Actual Mass (g) \\
\hline Water (deionized) & & $\sim 200.0$ & \\
Sodium Hydroxide & $\mathrm{NaOH}$ & $15.38 \pm 0.077$ & \\
Sodium Phosphate & $\mathrm{Na}_{3} \mathrm{PO}_{4} \cdot 12 \mathrm{H}_{2} \mathrm{O}$ & $15.38 \pm 0.077$ & \\
Sodium Oxalate & $\mathrm{Na}_{2} \mathrm{C}_{2} \mathrm{O}_{4}$ & $5.30 \pm 0.027$ & \\
\hline
\end{tabular}


4 Mix vigorously for $\sim 15$ minutes. Then add the above solution to the 2-L vessel.

5 Add to the 2-L vessel:

\begin{tabular}{llcl}
\hline Compounds & Formula & Target Mass $(\mathrm{g})$ & Actual Mass $(\mathrm{g})$ \\
\hline Sodium Carbonate & $\mathrm{Na}_{2} \mathrm{CO}_{3}$ & $102.3 \pm 0.51$ & \\
\hline
\end{tabular}

6 Mix vigorously for $\sim 15$ minutes.

7 In separate $250-\mathrm{mL}$ container, mix the following:

\begin{tabular}{|c|c|c|c|}
\hline Compounds & Formula & Target Mass (g) & Actual Mass (g) \\
\hline Sodium Nitrite & $\mathrm{NaNO}_{2}$ & $6.49 \pm 0.032$ & \\
\hline Water (deionized) & & $\sim 100$ & \\
\hline
\end{tabular}

8 Add to the 2-L vessel and mix vigorously for $\sim 15$ minutes.

9 Add to the 2-L vessel:

\begin{tabular}{|c|c|c|c|}
\hline & Total Mass Target (g) & Added & Mass of Water to Add $(\mathrm{g})$ \\
\hline DI Water to a total mass of: & 1000 & & $\sim 350$ \\
\hline
\end{tabular}

Record Final Mass of Vessel + solution:

Record Final Mass of solution:

\section{A.2-PREPARATION OF SUPERNATE SIMULANT}

This simulant is used for final washing of the Precipitated Sludge Solids and for makeup of the final overall simulant.

Note: $\leq \pm 0.5 \%$ is sufficient accuracy on masses.

The following recipe should be carried out in a plastic or stainless steel vessel. No glass shall be used. All additions are based on mass.

Note: The target volume is $1 \mathrm{~L}$.

Tare weight of 2-L vessel:

1- To a 2-L vessel, add:

\begin{tabular}{lccc}
\hline & Target Mass $(\mathrm{g})$ & Actual Mass $(\mathrm{g})$ & Resistivity of water \\
\hline Water (deionized, DI) & $\sim 200.0$ & \\
\hline
\end{tabular}


2- Add the Transition Metals, Complexing Agents, Halides, Sulfate, and Potassium to the 2-L vessel:

\begin{tabular}{llcc}
\hline Compounds & Formula & Target Mass $(\mathrm{g})$ & Actual Mass $(\mathrm{g})$ \\
\hline Potassium Nitrate & $\mathrm{KNO}_{3}$ & $0.4325 \pm 0.0022$ & \\
Sodium Chloride & $\mathrm{NaCl}$ & $0.2007 \pm 0.001$ & \\
Sodium Fluoride & $\mathrm{NaF}$ & $0.1345 \pm 0.0007$ & \\
Sodium Sulfate & $\mathrm{Na}_{2} \mathrm{SO}_{4}$ & $2.671 \pm 0.013$ & \\
\hline
\end{tabular}

3- In separate $250-\mathrm{mL}$ container, mix the following:

\begin{tabular}{llcc}
\hline Compounds & Formula & Target Mass $(\mathrm{g})$ & Actual Mass $(\mathrm{g})$ \\
\hline Water (deionized) & & $\sim 200$ \\
Sodium Hydroxide & $\mathrm{NaOH}$ & $15.380 \pm 0.077$ \\
Potassium Hydroxide & $\mathrm{KOH}$ & $0.2691 \pm 0.0013$ \\
Sodium Phosphate & $\mathrm{Na}_{3} \mathrm{PO}_{4} \cdot 12 \mathrm{H}_{2} \mathrm{O}$ & $15.380 \pm 0.077$ \\
Sodium Tungstate & $\mathrm{Na}_{2} \mathrm{WO}_{4} \cdot 2 \mathrm{H} 2 \mathrm{O}$ & $0.1577 \pm 0.0008$ \\
Sodium Metasilicate & $\mathrm{Na}_{2} \mathrm{SiO}_{3} \cdot 9 \mathrm{H}_{2} \mathrm{O}$ & $0.5455 \pm 0.0027$ \\
Sodium Formate & $\mathrm{NaHCOO}_{\text {Sadium Acetate }}$ & $0.2062 \pm 0.0010$ \\
Sodium Oxalate & $\mathrm{NaCH}_{3} \mathrm{COO} \cdot 3 \mathrm{H}_{2} \mathrm{O}$ & $1.034 \pm 0.005$ \\
\hline
\end{tabular}

4- Mix vigorously for $\sim 15$ minutes. Then add this solution to the 2 - $\mathrm{L}$ vessel. Add:

\begin{tabular}{llcl}
\hline Compounds & Formula & Target Mass $(\mathrm{g})$ & Actual Mass $(\mathrm{g})$ \\
\hline Sodium Carbonate & $\mathrm{Na}_{2} \mathrm{CO}_{3}$ & $102.30 \pm 0.51$ & \\
\hline
\end{tabular}

Mix vigorously for $\sim 15$ minutes.

5- In separate $250-\mathrm{mL}$ container, mix the following:

\begin{tabular}{llcc}
\hline Compounds & Formula & Target Mass $(\mathrm{g})$ & Actual Mass $(\mathrm{g})$ \\
\hline Sodium Nitrite & $\mathrm{NaNO}_{2}$ & $6.494 \pm 0.032$ & \\
Water (deionized) & & $\sim 100$ & \\
\hline
\end{tabular}

6- Add to the 2-L vessel and mix vigorously for $\sim 15$ minutes. Add:

\begin{tabular}{|c|c|c|c|}
\hline & Total Target Mass (g) & Added & Mass of Water to Add ( $\mathrm{g}$ ) \\
\hline DI Water to a total mass of: & 1000 & & 300 \\
\hline
\end{tabular}

7 Analyze the Supernate Simulant for wt $\%$ total solids by drying $10 \mathrm{~mL}$ at $110^{\circ} \mathrm{C}$ until a stable weight is obtained.

$\mathrm{Wt} \%$ total solids: 
8 Collect a 5- to 10-mL sample for ICP/IC analysis in a tared vial.

Sample wt:

\section{A.3-PREPARATION OF PRECIPITATED Fe-Rich SLUDGE SOLIDS}

This recipe details the steps to make precipitated Fe-rich sludge solids. The general steps involved are to dissolve metal nitrates, neutralize these nitrates to form the metal hydroxides, add trim chemicals (phosphate, oxalate, carbonate), and then wash the solids with the simple supernate for washing and then with the supernate.

Note: $\leq \pm 0.5 \%$ is sufficient accuracy on masses.

The following preparation should be carried out in a plastic or stainless steel vessel. No glass shall be used. All additions are based on mass.

Note: The target weight of precipitated solids is $\sim 60 \mathrm{~g}$.

Tare weight of 2-L vessel:

1- Add to the 2-L vessel:

\begin{tabular}{ccc}
\hline & Target Mass $(\mathrm{g})$ & Actual Mass $(\mathrm{g})$ \\
\hline Deionized Water & $\sim 300$ & \\
\hline
\end{tabular}

\section{A.3.1-MANGANESE DIOXIDE PRODUCTION}

2- Add to the 2-L vessel:

\begin{tabular}{llcc}
\hline Compounds & Formula & Target Mass $(\mathrm{g})$ & Actual Mass $(\mathrm{g})$ \\
\hline Potassium Permanganate & $\mathrm{KMnO}_{4}$ & $4.37 \pm 0.022$ & \\
\hline
\end{tabular}

Compound should completely dissolve.

3- Add to the 2-L vessel:

\begin{tabular}{llcc}
\hline Compounds & Formula & Target Mass $(\mathrm{g})$ & Actual Mass $(\mathrm{g})$ \\
\hline Manganous Nitrate Solution & $\mathrm{Mn}\left(\mathrm{NO}_{3}\right)_{2}, 50 \mathrm{Wt} \%$ solution & $14.85 \pm 0.074$ & \\
\hline
\end{tabular}

Mix vigorously for $\sim 15$ minutes. It will produce fine black solids which will remain suspended while being agitated.

\section{A.3.2-PREPARATION OF METAL HYDROXIDES}

4 Add to the 2-L vessel the following transition and other metal compounds with mixing to make certain that dissolution is complete (order of addition not believed important): 


\begin{tabular}{|c|c|c|c|}
\hline Compounds & Formula & Target Mass $(\mathrm{g})$ & Actual Mass (g) \\
\hline Barium Nitrate & $\mathrm{Ba}\left(\mathrm{NO}_{3}\right)_{2}$ & $0.213 \pm 0.001$ & \\
\hline Calcium Nitrate & $\mathrm{Ca}\left(\mathrm{NO}_{3}\right)_{2} \cdot 4 \mathrm{H}_{2} \mathrm{O}$ & $2.425 \pm 0.012$ & \\
\hline Cadmium Nitrate & $\mathrm{Cd}\left(\mathrm{NO}_{3}\right)$ & $0.06 \pm 0.0003$ & \\
\hline Cerium Nitrate & $\mathrm{Ce}\left(\mathrm{NO}_{3}\right)_{3} \cdot 6 \mathrm{H}_{2} \mathrm{O}$ & $0.65 \pm 0.003$ & \\
\hline Copper Nitrate & $\mathrm{Cu}\left(\mathrm{NO}_{3}\right)_{2} \cdot 3 \mathrm{H}_{2} \mathrm{O}$ & $0.157 \pm 0.0008$ & \\
\hline Ferric Nitrate & $\mathrm{Fe}\left(\mathrm{NO}_{3}\right)_{3} \cdot 9 \mathrm{H}_{2} \mathrm{O}$ & $128.1 \pm 0.64$ & \\
\hline Lanthanum Nitrate & $\mathrm{La}\left(\mathrm{NO}_{3}\right)_{3} \cdot 6 \mathrm{H}_{2} \mathrm{O}$ & $0.482 \pm 0.002$ & \\
\hline Lead Nitrate & $\mathrm{Pb}\left(\mathrm{NO}_{3}\right)_{2}$ & $1.295 \pm 0.006$ & \\
\hline Magnesium Nitrate & $\mathrm{Mg}\left(\mathrm{NO}_{3}\right)_{2} \cdot 6 \mathrm{H}_{2} \mathrm{O}$ & $1.72 \pm 0.009$ & \\
\hline Neodymium Nitrate & $\mathrm{Nd}\left(\mathrm{NO}_{3}\right)_{3} \cdot 6 \mathrm{H}_{2} \mathrm{O}$ & $1.32 \pm 0.007$ & \\
\hline Nickel Nitrate & $\mathrm{Ni}\left(\mathrm{NO}_{3}\right)_{2} \cdot 6 \mathrm{H}_{2} \mathrm{O}$ & $2.87 \pm 0.014$ & \\
\hline Praseodymium Nitrate & $\operatorname{Pr}\left(\mathrm{NO}_{3}\right)_{3} \cdot \mathrm{xH} \mathrm{H}_{2} \mathrm{O} \sim 6$ & $0.33 \pm 0.002$ & \\
\hline Ruthenium Trichloride & $\mathrm{RuCl}_{3}$ & $0.11 \pm 0.0005$ & \\
\hline Silver Nitrate & $\mathrm{AgNO}_{3}$ & $0.486 \pm 0.002$ & \\
\hline Strontium Nitrate & $\mathrm{Sr}\left(\mathrm{NO}_{3}\right)_{2}$ & $0.347 \pm 0.002$ & \\
\hline Yttrium Nitrate & $\mathrm{Y}\left(\mathrm{NO}_{3}\right)_{3} \cdot 6 \mathrm{H}_{2} \mathrm{O}$ & $0.14 \pm 0.0007$ & \\
\hline Zinc Nitrate & $\mathrm{Zn}\left(\mathrm{NO}_{3}\right)_{2} \cdot 6 \mathrm{H}_{2} \mathrm{O}$ & $0.169 \pm 0.0008$ & \\
\hline Zirconyl Nitrate & $\mathrm{ZrO}\left(\mathrm{NO}_{3}\right)_{2} \cdot \mathrm{xH}_{2} \mathrm{O} \quad \mathrm{x} \sim 6$ & $1.73 \pm 0.009$ & \\
\hline Mercuric Nitrate & $\mathrm{Hg}\left(\mathrm{NO}_{3}\right)_{2}$ & $0.052 \pm 0.0003$ & \\
\hline
\end{tabular}

5 Mix vigorously in order to completely dissolve everything except the fine black solids of $\mathrm{MnO}_{2}$. A little deionized water may be added if necessary for complete dissolution to occur.

DIW water added:

\section{A.3.3-NEUTRALIZATION OF NITRATE SOLUTION}

6 Standardize a pH electrode with $\mathrm{pH} \mathrm{4,} \mathrm{7,} \mathrm{and} 10$ buffers.

pH 4 buffer:

Manufacturer: Lot\#: Exp Date:

pH 7 buffer:

Manufacturer: Lot\#: Exp Date:

pH 10 buffer: Manufacturer: Lot\#: Exp Date:

7 Place the $\mathrm{pH}$ electrode in the precipitation vessel with the metal nitrates and measure the $\mathrm{pH}$. 
$\mathrm{pH}$ : Note: $\mathrm{pH}$ should be $<1$.

With the nitrate solution agitating, slowly add 8-M NaOH until the $\mathrm{pH}$ reaches 10 to 11 . Estimated amount of 8-M NaOH needed is $190 \mathrm{~g}$.

8 Measure the $\mathrm{pH}$.

$\mathrm{pH}:$

9 Continue mixing for 1 hour and then recheck $\mathrm{pH}$.

$\mathrm{pH}$ :

10 Add additional $8 \mathrm{M} \mathrm{NaOH}$ to return the $\mathrm{pH}$ to 10 if it is lower.

Total $8 \mathrm{M} \mathrm{NaOH}$ added:

Final $\mathrm{pH}$ :

\section{A.3.4-ADDITION OF ADDITIONAL REAGENTS}

11 Add to the 2-L vessel:

\begin{tabular}{llcc}
\hline Compounds & Formula & Target Mass $(\mathrm{g})$ & Actual Mass $(\mathrm{g})$ \\
\hline Calcium Fluoride & $\mathrm{CaF}_{2}$ & $0.205 \pm 0.001$ & \\
Sodium Phosphate & $\mathrm{Na}_{3} \mathrm{PO}_{4} \cdot 12 \mathrm{H}_{2} \mathrm{O}$ & $5.05 \pm 0.03$ & \\
\hline
\end{tabular}

12 Combine the following in a separate $250-\mathrm{mL}$ container while stirring:

\begin{tabular}{lccc}
\hline Compound & Formula & Target Mass $(\mathrm{g})$ & Actual Mass $(\mathrm{g})$ \\
\hline Water (deionized) & & $\sim 100$ & \\
Sodium Oxalate & $\mathrm{Na}_{2} \mathrm{C}_{2} \mathrm{O}_{4}$ & $6.7 \pm 0.03$ & \\
\hline
\end{tabular}

Add this sodium oxalate solution to the 2-L vessel while stirring.

13 Combine the following in a separate $250-\mathrm{mL}$ container while stirring:

\begin{tabular}{lccc}
\hline Compound & Formula & Target Mass $(\mathrm{g})$ & Actual Mass $(\mathrm{g})$ \\
\hline Water (deionized) & & $\sim 100$ & \\
Sodium Carbonate & $\mathrm{Na}_{2} \mathrm{CO}_{3}$ & $9.50 \pm 0.05$ & \\
\hline
\end{tabular}

Add this sodium carbonate solution to the $2-\mathrm{L}$ vessel with stirring. Approximate volume at this point should be about $0.9 \mathrm{~L}$.

14 Mix (vigorously) the slurry to ensure good mixing. Mix the slurry for at least 1 hour. 


\section{A.3.5-WASH PRECIPITATED SLUDGE SOLIDS TO REMOVE NITRATE}

Four washes are performed to reduce the nitrate concentration to below about $500 \mathrm{mg} / \mathrm{kg}$. The slurry is centrifuged between each wash. The total solids content of the centrifuged solids needs to be at least $25 \mathrm{wt} \%$ for sufficient washing to be completed in four washes. If less wash solution is removed during centrifuging, additional washing steps must be added. However, excessive washing is to be avoided so that the nitrate and trace compounds are not reduced in concentration too far.

The amount of wash solution required per wash is approximately 3 times the mass of the centrifuged solids. Three washes with the "simple supernate for washing" are used, followed by a wash with the actual "supernate simulant." Use this information to calculate the amount of wash and supernate simulant needed.

15 Centrifuge the slurry for 30 minutes at $\sim 4500 \mathrm{G}$.

Time started: Time finished:

Centrifuge speed:

16 Decant the supernate. (The supernate is waste.)

Amount of supernate decanted:

17 Combine all centrifuged slurry fractions.

Weight of centrifuged solids:

18 Measure the nitrate concentration of the slurry using the nitrate probe for indication.

$\mathrm{NO}_{3}{ }^{-}$concentration:

19 Add "AY-102 simple simulant for washing" at approximately 3 times the mass of the slurry and mix thoroughly (for $\sim 1$ hour).

Amount of wash solution added:

20 Centrifuge the slurry for 30 minutes at $\sim 4500 \mathrm{G}$.

Time started: Time finished:

Centrifuge speed:

21 Decant the supernate. (The supernate is waste.) End of Wash 1

Amount of supernate decanted:

22 Combine all centrifuged slurry fractions. 
Weight of centrifuged solids:

23 Measure the nitrate concentration of the slurry using the nitrate probe for indication.

$\mathrm{NO}_{3}{ }^{-}$concentration:

24 Add "AY-102 simple simulant for washing" at approximately 3 times the mass of the slurry and mix thoroughly (for $\sim 1$ hour).

Amount of wash solution added:

25 Centrifuge the slurry for 30 minutes at $\sim 4500 \mathrm{G}$.

Time started: Time finished:

Centrifuge speed:

26 Decant the supernate. (The supernate is waste.) End of Wash 2

Amount of supernate decanted:

27 Combine all centrifuged slurry fractions.

Weight of centrifuged solids:

28 Measure the nitrate concentration of the slurry using the nitrate probe for indication.

$\mathrm{NO}_{3}{ }^{-}$concentration:

29 Add "AY-102 simple simulant for washing" at approximately 3 times the mass of the slurry and mix thoroughly (for $\sim 1$ hour).

Amount of wash solution added:

30 Centrifuge the slurry for 30 minutes at $\sim 4500 \mathrm{G}$.

Time started: Time finished:

Centrifuge speed:

31 Decant the supernate. (The supernate is waste.) End of Wash $\mathbf{3}$

Amount of supernate decanted:

32 Combine all centrifuged slurry fractions.

Weight of centrifuged solids: 
33 Measure the nitrate concentration of the slurry using the nitrate probe for indication.

$\mathrm{NO}_{3}{ }^{-}$concentration:

34 Add ACTUAL supernate simulant (the batch to be used for the final combined simulant) at approximately 3 times the mass of the slurry and mix thoroughly (for $\sim 1$ hour).

Amount of wash solution added:

35 Centrifuge the slurry for 30 minutes at $\sim 4500 \mathrm{G}$.

Time started: Time finished:

Centrifuge speed:

36 Decant the supernate. (The supernate is waste.) End of Wash 4

Amount of supernate decanted:

37 Combine all centrifuged slurry fractions.

Weight of centrifuged solids:

38 Measure the nitrate concentration of the slurry using the nitrate probe for indication.

$\mathrm{NO}_{3}{ }^{-}$concentration:

39 Add ACTUAL supernate simulant (the batch to be used for the final combined simulant) at approximately 3 times the mass of the slurry and mix thoroughly (for $\sim 1$ hour).

Amount of wash solution added:

40 Add to the 2-L vessel with agitation:

\begin{tabular}{llcc}
\hline Compounds & Formula & Target Mass $(\mathrm{g})$ & Actual Mass $(\mathrm{g})$ \\
\hline Sodium Carbonate & $\mathrm{Na}_{2} \mathrm{CO}_{3}$ & $156.0 \pm 0.78$ & \\
\hline
\end{tabular}

41 Centrifuge the slurry for 30 minutes at $\sim 4500 \mathrm{G}$.

Time started: Time finished:

Centrifuge speed:

42 Decant the supernate. (The supernate is waste.) End of Wash $\mathbf{5}$

Amount of supernate decanted: 
43 Measure the nitrate concentration of the slurry using the nitrate probe for indication. If $<500 \mathrm{mg} / \mathrm{kg}$, continue to next step. If not, then perform another washing step.

$\mathrm{NO}_{3}{ }^{-}$concentration:

44 Analyze the slurry for $w t \%$ total solids and $w t \%$ supernate solids ( $w t \%$ solids of supernate separated from the slurry) by drying at $110^{\circ} \mathrm{C}$.

$\mathrm{Wt} \%$ total solids:

$\mathrm{Wt} \%$ supernate solids:

\section{Acceptance Criteria}

The acceptance criteria below apply to the PEP simulant. This is a good example of the criteria that might be required of a simulant vendor. These criteria are chosen to control the important features of the simulant, which are based on the application of the simulant. Hence, for another simulant, there could be an adjusted set of criteria that reflects another application.

Specific Supernate (i.e., Step 7 of Section A.2)

- Shall be $5.0 \pm 0.5 \underline{\mathrm{M}}$ sodium, e.g., $5.0 \pm 10 \%(0.5 \underline{\mathrm{M}} \mathrm{Na})$

- Anion concentrations in final supernate shall be $\pm 10 \%$ of target calculated from amounts added and final volume.

Fe-rich Solids Slurry (Step 14 of Section A.3)

- Concentrations in the liquid phase of the slurry shall match the specific supernate acceptance criteria within $\pm 10 \%$ in all categories or as determined by the technical administrator.

- The mass ratio of iron to other elements in the UDS shall be as given in Table A.1 within $\pm 10 \%$ for the elements whose mass ratio to iron is greater than 0.01 and within $\pm 20 \%$ for the elements whose mass ratio to iron is less than 0.01 or as determined by the technical administrator. Because of the very, very low solubility of zirconium, phosphate analysis of $\mathrm{Zr}$ is difficult in this high-phosphate medium, and it might not be observed without sophisticated analytical methods; we have successfully observed $80 \%$ of added $\mathrm{Zr}$ for this material.

Simulant (as shipped, not including the specific supernate set aside for rinsing)

- Shall contain $\geq 5.8 \mathrm{wt} \%$ UDS.

- Liquid phase shall be $5.0 \pm 0.5 \underline{\mathrm{M}} \mathrm{Na}$.

- Concentrations in the liquid phase of the slurry (as defined at the beginning of Section 4) shall match the specific supernate acceptance criteria within $\pm 10 \%$ in all categories.

- The mass ratio of iron to other elements in the simulant slurry shall be as given in Table A.1 within $\pm 10 \%$ for the elements whose mass ratio to iron is greater than 0.01 and within $\pm 20 \%$ for the elements whose mass ratio to iron is less than 0.01 . Because of the very, very low solubility of zirconium, phosphate analysis of $\mathrm{Zr}$ is difficult in this high-phosphate medium, and it might not be observed without sophisticated analytical methods; we have successfully observed $80 \%$ of added $\mathrm{Zr}$ for this material. 
Table A.1. Expected Mass Batching Ratios for the UDS in Fe-Rich Slurry Simulant

\begin{tabular}{cc}
\hline Element & Mass Element/Mass Fe \\
\hline $\mathrm{Mn}$ & 0.214 \\
$\mathrm{Ca}$ & 0.029 \\
$\mathrm{Ce}$ & 0.012 \\
$\mathrm{Fe}$ & 1.000 \\
$\mathrm{La}$ & 0.0087 \\
$\mathrm{~Pb}$ & 0.046 \\
$\mathrm{Mg}$ & 0.0092 \\
$\mathrm{Nd}$ & 0.024 \\
$\mathrm{Ni}$ & 0.033 \\
$\mathrm{Sr}$ & 0.0081 \\
$\mathrm{Zr}$ & 0.026 \\
\hline
\end{tabular}

Use 24590-WTP-GPG-RTD-001, Revision 0, Guidelines for Performing Chemical, Physical, and Rheological Properties Measurements, Effective Date: 05/20/02, which describes the measurements and calculation method to be used to determine the wt $\%$ UDS.

\section{Reference}

Russell RL, DE Rinehart, JM Billing, HD Smith, and RA Peterson. 2009. Development and Demonstration of Ultrafiltration Simulants. PNNL-18090, WTP-RPT-183 Rev. 0, Pacific Northwest National Laboratory, Richland, Washington. 

Appendix B

\section{Simulant 1 Preparation}





\section{Appendix B: Simulant 1 Preparation}

Simulant 1 is made up from the list of prefabricated components shown in Table B.1. A vendor prepared the supernate and the Fe-bearing sludge to the recipe described in Appendix A. The gibbsite, boehmite, and sodium oxalate components were commercially purchased.

Table B.1. Blended Simulant Recipe for 5L

\begin{tabular}{|c|c|c|}
\hline & Ingredients & Amount Used \\
\hline 1 & $\begin{array}{l}\text { Centrifuge Optima prepared Fe-bearing sludge to } \\
\sim 22 \mathrm{wt} \% \text { UDS until enough solids have been } \\
\text { obtained. }\end{array}$ & $\begin{array}{l}5991.92 \text { g Fe-bearing sludge centrifuged to } \\
\text { obtain } 2802.63 \text { g solids. }\end{array}$ \\
\hline 2 & $\begin{array}{l}\text { Add } 2799.50 \mathrm{~g} \text { Fe-bearing } \sim 22 \mathrm{wt} \% \text { UDS sludge } \\
\text { with mixing. }\end{array}$ & $2802.63 \mathrm{~g}$ added. \\
\hline 3 & $\begin{array}{l}\text { Add } 3070.15 \mathrm{~g} \mathrm{NaOH} \text { shimmed supernate from } \\
\text { Optima. }\end{array}$ & $3070.16 \mathrm{~g}$ added. \\
\hline 4 & Add 1165.17 g Almatis C333 gibbsite. & $1165.19 \mathrm{~g}$ added. \\
\hline 5 & Add 1165.17 g APYRAL AOH20 boehmite. & $1165.18 \mathrm{~g}$ added. \\
\hline 6 & Add 336.76 g sodium oxalate. & $336.77 \mathrm{~g}$ added. \\
\hline 7 & Actively mix the entire batch for 1 hour. & \\
\hline
\end{tabular}

The APYRAL AOH20 boehmite mineral powder manufacturer characterization is provided below. 


\section{APYRAL ${ }^{\circledR}$ \\ Provisional Product Information APYRAL AOH 20, APYRAL AOH 20Y, APYRAL AOH 60}

Mineral flame retardants for

- Wire and cable industry

- Electronic industry

- Public Transport

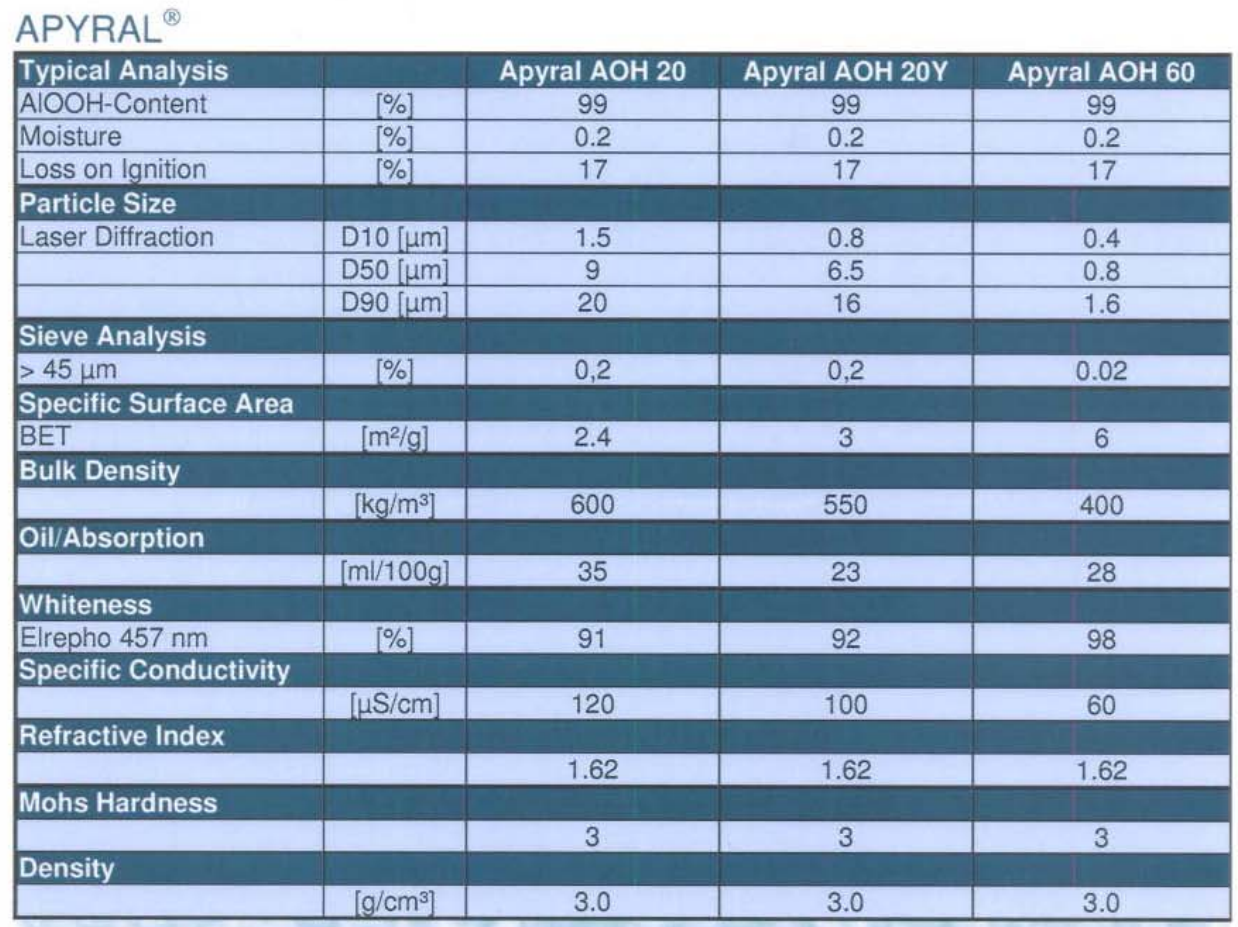

\section{Produktvorteile / Product properties}

High temperature stability up to $320^{\circ} \mathrm{C}$ for high temperature applications

- Various particle size distributions for different applications

Low sedimentation and good viscosity performance in resins

Good char promoter

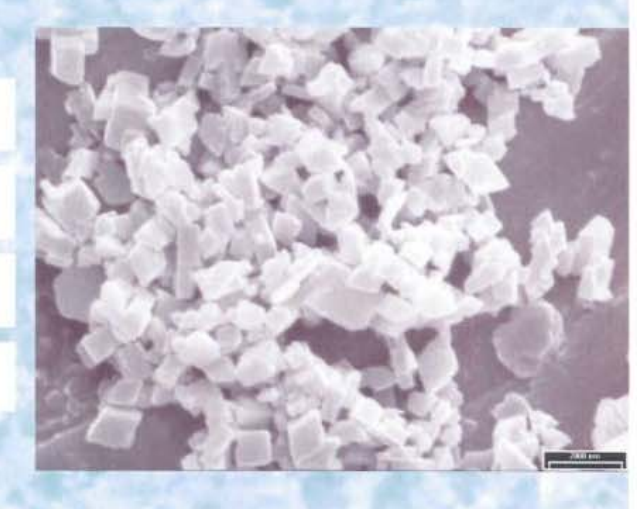

All this Data are provisional and only for information of the user. They do not describe legally binding properties. It remains the responsibility of the users to test the suitability of the products for the application.

The Almatis C333 gibbsite mineral powder manufacturer characterization is provided below. 


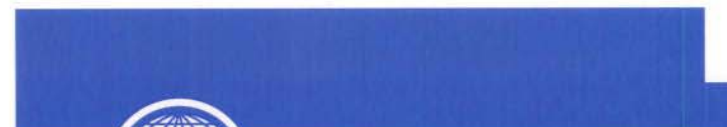

Global Product Data

\section{Alumina Trihydroxides Exceptionally Pure White Hydrates}

\section{Product Information}

Almatis white hydrated alumina is aluminum trihydroxide, $\mathrm{Al}(\mathrm{OH})_{3}$, that is produced through special processing of alumina-bearing feedstocks and stringent process control systems. The result is an aluminum trihydroxide of exceptional purity and whiteness. Although aluminum trihydroxide is a dry powder, it contains a high proportion, approximately 35 percent by weight, of chemically combined water. The hydrate is a nonabrasive, low-density material with a Mohs hardness index of 2.5-3.5 and a specific gravity of 2.42. White hydrates are used primarily in applications where color and the absence of impurities are critical. They are halogen-free making them excellent nontoxic flame retardant/smoke suppressant fillers for plastic compounds.

\section{Product Description}

Almatis precipitates a highly pure gibbsite phase of alpha alumina trihydrate. The Almatis proprietary white stream process is designed, through chemical and recrystallization processes, to achieve near 100 percent photovolt brightness and relatively uniform particles.

\section{C-33 and C-31C (coarse)}

The precipitation process is controlled to produce two median particle sizes, Grades C-33 (50 microns) and C-31C (85 microns). Both grades have free-flowing properties.

\section{C-333 Ground White Hydrates}

A fine size grade is produced by grinding the precipitated grade to form C-333 (7 microns).

\section{Applications}

Grades C-33 and C-31C hydrates are used in the manufacture of glass, chemicals, catalysts, vitreous enamels and ceramic whitewares, and as additives in high quality pigments. These products are also used as additives and fillers in polymer systems such as electrical wire insulation and high quality cultured onyx and solid countertop surfacing material. Aluminum trihydroxides are preferred because of their good arc and track resistance, aesthetic properties, reinforcing characteristics, and performance as nontoxic smoke suppressants and flame retardants.

C-333 is a ground version of the precipitated grade. It is used in polymer formulations, toothpastes, adhesives, coatings, paper, cosmetics, waxes, and polishes.

Think alumina, think Almatis. 


\section{Alumina Trihydroxides Exceptionally Pure White Hydrates}

\begin{tabular}{|c|c|c|c|c|}
\hline \multirow[t]{2}{*}{ Product } & \multicolumn{3}{|c|}{ Aluminum Trihydroxides } & \multirow[b]{2}{*}{ Test Methods } \\
\hline & $C-33$ & $C-31 C$ & $C-333$ & \\
\hline \multicolumn{5}{|l|}{ Chemical Composition (\%) } \\
\hline $\mathrm{Al}(\mathrm{OH})_{3}(\mathrm{~min})$ & 99.6 & 99.6 & 99.6 & Difference \\
\hline $\mathrm{SiO}_{2}$ & 0.003 & 0.003 & 0.003 & \multirow{3}{*}{$\begin{array}{l}\text { DC Arc Opfical } \\
\text { Emission Spectrometry }\end{array}$} \\
\hline $\mathrm{Fe}_{2} \mathrm{O}_{3}$ & 0.009 & 0.009 & 0.009 & \\
\hline $\mathrm{Na}_{2} \mathrm{O}$ (total) & 0.20 & 0.26 & 0.17 & \\
\hline $\mathrm{Na}_{2} \mathrm{O}$ (soluble) & 0.008 & 0.008 & 0.026 & Hame Emission Photometry \\
\hline Moisture & 0.08 & 0.08 & 0.26 & Microwave \\
\hline \multicolumn{5}{|l|}{ Physical Properties } \\
\hline Loose bulk density $\left(\mathrm{g} / \mathrm{cm}^{3}\right)$ & 1.07 & 1.15 & 0.76 & Modified ASTM B212-89 \\
\hline Packed bulk density $\left(\mathrm{g} / \mathrm{cm}^{3}\right)$ & 1.3 & 1.3 & 1.15 & Modified ASTM B527-85 \\
\hline Refractive index & 1.57 & 1.57 & 1.57 & \\
\hline Mohs hardness & $2.5-3.5$ & $2.5-3.5$ & $2.5-3.5$ & \\
\hline Density $\left(\mathrm{g} / \mathrm{cm}^{3}\right)$ & 2.42 & 2.42 & 2.42 & \\
\hline Surface area $\left(\mathrm{m}^{2} / \mathrm{g}\right)$ & . & . & 3.0 & $\mathrm{BET}$ \\
\hline LOI (\%) & 34.6 & 34.6 & 34.6 & From $110-1100^{\circ} \mathrm{C}$ \\
\hline Color & White & White & White & \\
\hline \multicolumn{5}{|l|}{ Particle Size Distribution } \\
\hline$\%$ on 100 Tyler mesh & 0 & 0 & - & \\
\hline$\%$ on 200 Tyler mesh & 8 & 45 & 0 & \\
\hline$\%$ on 325 Tyler mesh & 60 & 90 & 1 & \\
\hline \% through 325 Tyler mesh & 40 & 10 & 99 & Wet Screen \\
\hline $\mathrm{d} 50(\mu)$ & 50 & 85 & 7 & Sedigraph 5100 or Microtroc \\
\hline
\end{tabular}

2003 Data - All data are based upon Almatis standard test methods, and all test methods are available upon request. Unless stated otherwise values are typical. 
Appendix C

\section{Recipe for Simulant 2 Preparation}





\section{Appendix C: Recipe for Simulant 2 Preparation}

The following is a step-by-step recipe for preparing the simulant for the tank combination of tanks AN-101, C-104, C-111, and C-112. Note: The component make-up procedures are for a specified target volume or weight UDS, so multiples of the target values are generally made up when the wt\% UDS and the volume of the simulant batch are known. The simulant had many of the minor waste components left out to lower the toxicity of the resultant simulant and make it easier to dispose of.

\section{C.1-PREPARATION OF PRECIPITATED SLUDGE SOLIDS}

This recipe details the steps to make the precipitated sludge solids portion of the simulant. The general steps involved are to dissolve metal nitrates, neutralize these nitrates to form the metal hydroxides, add trim chemicals (phosphate, oxalate, carbonate), and then wash the solids with the simple supernate for washing and then with the supernate.

An accuracy of $0.5 \%$ on masses and volumes is sufficient.

The following preparation should be carried out in a plastic or stainless steel vessel. No glass shall be used. All additions are based on mass.

Tare weight of 20-L vessel:

4- Add to the 20-L vessel:

\begin{tabular}{ccc}
\hline & Mass Needed $(\mathrm{g})$ & Actual Mass $(\mathrm{g})$ \\
\hline Deionized Water & $\sim 6000$ & \\
\hline
\end{tabular}

5- Add to the 20-L vessel:

\begin{tabular}{llcc}
\hline Compounds & Formula & Mass Needed $(\mathrm{g})$ & Actual Mass $(\mathrm{g})$ \\
\hline Manganous Nitrate Solution & $\mathrm{Mn}\left(\mathrm{NO}_{3}\right) 2,50 \mathrm{Wt} \%$ solution & 255.33 & \\
\hline
\end{tabular}

Mix thoroughly.

\section{C.1.1-PREPARATION OF METAL HYDROXIDES}

3- Add to the 20-L vessel the following transition and other metal compounds with mixing to make certain that dissolution is complete: 


\begin{tabular}{llcc}
\hline Compounds & Formula & Mass Needed $(\mathrm{g})$ & Actual Mass $(\mathrm{g})$ \\
\hline Calcium Nitrate & $\mathrm{Ca}\left(\mathrm{NO}_{3}\right)_{2} \cdot 4 \mathrm{H}_{2} \mathrm{O}$ & 633.96 & \\
Ferric Nitrate & $\mathrm{Fe}\left(\mathrm{NO}_{3}\right)_{3} \cdot 9 \mathrm{H}_{2} \mathrm{O}$ & 2287.99 & \\
Neodymium Nitrate & $\mathrm{Nd}\left(\mathrm{NO}_{3}\right)_{3} \cdot 6 \mathrm{H}_{2} \mathrm{O}$ & 647.41 & \\
Nickel Nitrate & $\mathrm{Ni}\left(\mathrm{NO}_{3}\right)_{2} \cdot 6 \mathrm{H}_{2} \mathrm{O}$ & 448.63 & \\
\hline
\end{tabular}

4- Mix thoroughly in completely dissolve everything. A little deionized water may be added if necessary for complete dissolution to occur.

DIW water added:

\section{C.1.2. NEUTRALIZATION OF NITRATES}

5- Prepare $4 \mathrm{~L}$ of 8-M NaOH and add $93.24 \mathrm{~g} \mathrm{KOH}$.

Amount of $\mathrm{NaOH}$ needed: $1280 \mathrm{~g}$

Amount of $\mathrm{NaOH}$ added:

Amount of $\mathrm{KOH}$ added:

Amount of DIW added:

6-Standardize a $\mathrm{pH}$ electrode with $\mathrm{pH}$ 4, 7 and 10 buffers.

pH 4 buffer:

Manufacturer:

Lot\#:

Exp Date:

pH 7 buffer:

Manufacturer:

Lot\#:

Exp Date:

pH 10 buffer:

Manufacturer: Lot\#: Exp Date:

7- Place the $\mathrm{pH}$ electrode in the precipitation vessel with the metal nitrates and measure the $\mathrm{pH}$.

$\mathrm{pH}$ : Note: $\mathrm{pH}$ should be $<1$.

With the nitrate solution agitating, slowly add 8-M NaOH until the $\mathrm{pH}$ reaches 10 to 11 . The estimated amount of 8-M NaOH needed is about $3.75 \mathrm{~L}$.

8- Measure the $\mathrm{pH}$.

$\mathrm{pH}$ :

9- Continue mixing for 1 hour and then recheck $\mathrm{pH}$. 
$\mathrm{pH}$ :

10- Add additional 8-M NaOH to return the $\mathrm{pH}$ to 10 if it is lower.

Total 8-M NaOH added:

Final pH:

11- Thoroughly mix the slurry to verify good mixing. Mix the slurry for at least 1 hour.

\section{C.2-PREPARATION OF SUPERNATE SIMULANT}

This simulant is used for makeup of the final overall simulant.

An accuracy of $0.5 \%$ on masses and volumes is sufficient.

The following recipe should be carried out in a plastic or stainless steel vessel. No glass shall be used. All additions are based on mass.

7- To the 20-L vessel, add:

\begin{tabular}{llcc}
\hline Compounds & Formula & Mass Needed $(\mathrm{g})$ & Actual Mass $(\mathrm{g})$ \\
\hline Sodium Chloride & $\mathrm{NaCl}$ & 37.75 & \\
Sodium Fluoride & $\mathrm{NaF}$ & 435.30 & \\
Sodium Sulfate & $\mathrm{Na}_{2} \mathrm{SO}_{4}$ & 109.70 & \\
\hline
\end{tabular}

8- Then add the following:

\begin{tabular}{llcc}
\hline Compounds & Formula & Mass Needed $(\mathrm{g})$ & Actual Mass $(\mathrm{g})$ \\
\hline Sodium Phosphate & $\mathrm{Na}_{3} \mathrm{PO}_{4} \cdot 12 \mathrm{H}_{2} \mathrm{O}$ & 1457.11 & \\
Sodium Acetate & $\mathrm{NaCH}_{3} \mathrm{COO} \cdot 3 \mathrm{H}_{2} \mathrm{O}$ & 129.02 & \\
Sodium Oxalate & $\mathrm{Na}_{2} \mathrm{C}_{2} \mathrm{O}_{4}$ & 255.73 & \\
\hline
\end{tabular}

9- Mix thoroughly. Then add this to the 20-L vessel:

\begin{tabular}{llcl}
\hline Compounds & Formula & Mass Needed (g) & Actual Mass (g) \\
\hline Sodium Carbonate & $\mathrm{Na}_{2} \mathrm{CO}_{3}$ & 774.44 & \\
\hline
\end{tabular}

10- Mix thoroughly. Then add the following the following:

\begin{tabular}{llcl}
\hline Compounds & Formula & Mass Needed $(\mathrm{g})$ & Actual Mass $(\mathrm{g})$ \\
\hline Sodium Nitrite & $\mathrm{NaNO}_{2}$ & 994.81 & \\
\hline
\end{tabular}




\section{C.3-FINAL SOLIDS ADDITION TO SIMULANT}

1-After all parts of the simulant have been combined in the proper ratios, add:

\begin{tabular}{lcc}
\hline Additive & Amount (g) & Amount Added (g) \\
\hline $\mathrm{SiO}_{2}$ & 162.14 & \\
$\mathrm{ZrO}_{2}$ & 475.03 & \\
$\mathrm{Al}(\mathrm{OH})_{3}$ (gibbsite) & 2465.82 & \\
\hline
\end{tabular}

2-Add to the 20-L vessel and mix thoroughly. Add:

\begin{tabular}{lcc}
\hline & Total Mass Volume (L) & Added \\
\hline DI Water to a total mass of: & 15 & \\
\hline
\end{tabular}

3- Analyze the Simulant for wt $\%$ total solids by drying $10 \mathrm{~mL}$ at $110^{\circ} \mathrm{C}$ until a stable weight is obtained or using a moisture analyzer.

$\mathrm{Wt} \%$ total solids:

4- Collect a 5- to 10-mL sample for ICP/IC analysis. Sample \# S2-FS-B1-1.

Sample wt: 
Appendix D

\section{Simulant 2 Liquid Viscosity Flow Curves}





\section{Appendix D: Simulant 2 Liquid Viscosity Flow Curves}

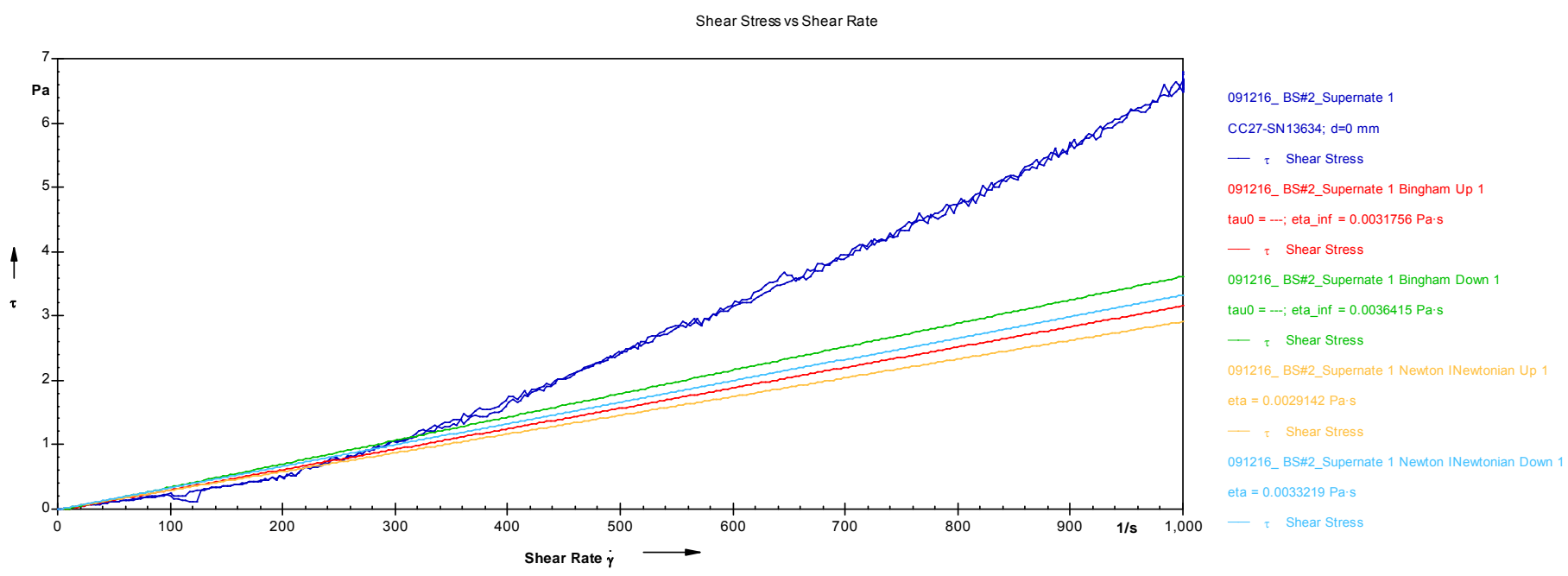

Figure D.1. Simulant 2 Liquid Viscosity Flow Curve

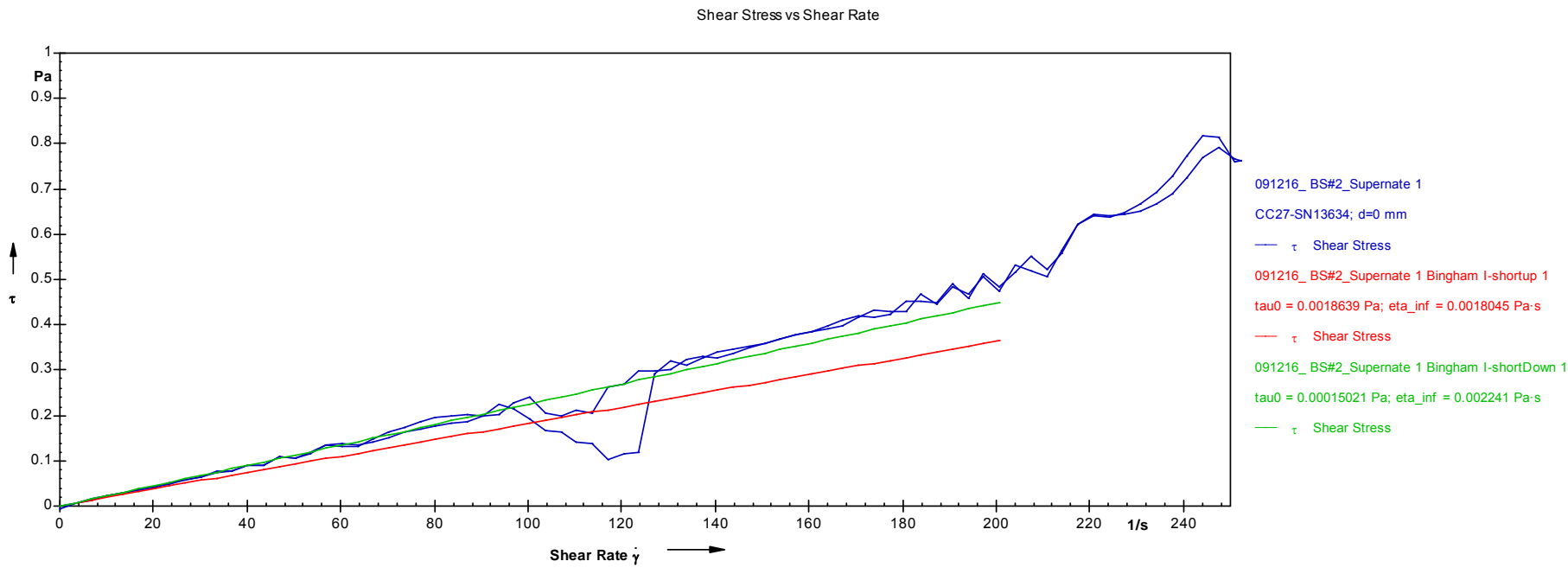

Figure D.2. Simulant 2 Liquid Viscosity Flow Curve, 0 to 250 1/s 

Appendix E

Simulant PSD Data 



\section{Appendix E: Simulant PSD Data}

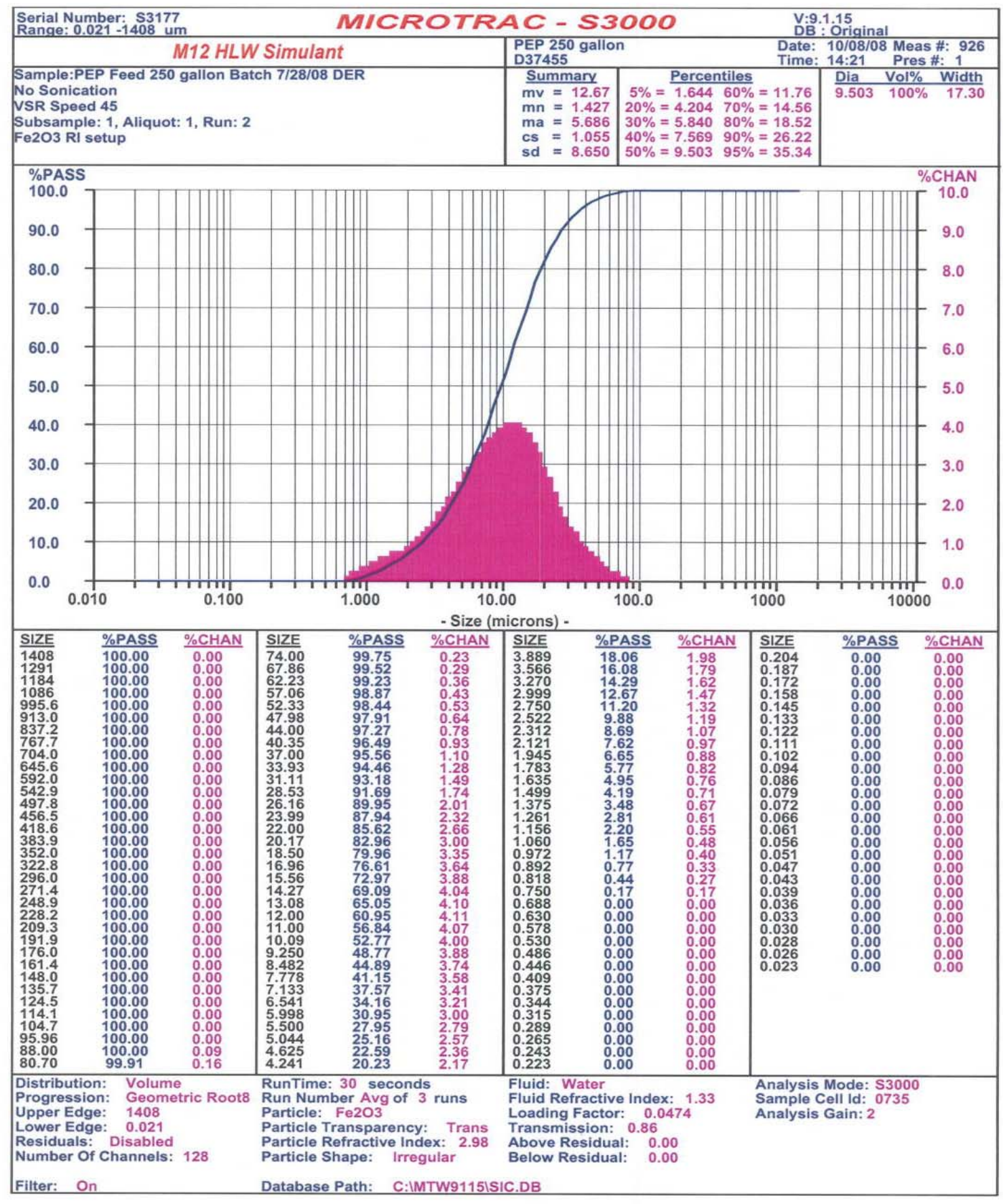

Figure E.1. Simulant 1 PSD. Russell et al. (2009), Appendix A, Sample: PEP Feed 250 gallon Batch 7/28/08 DER 


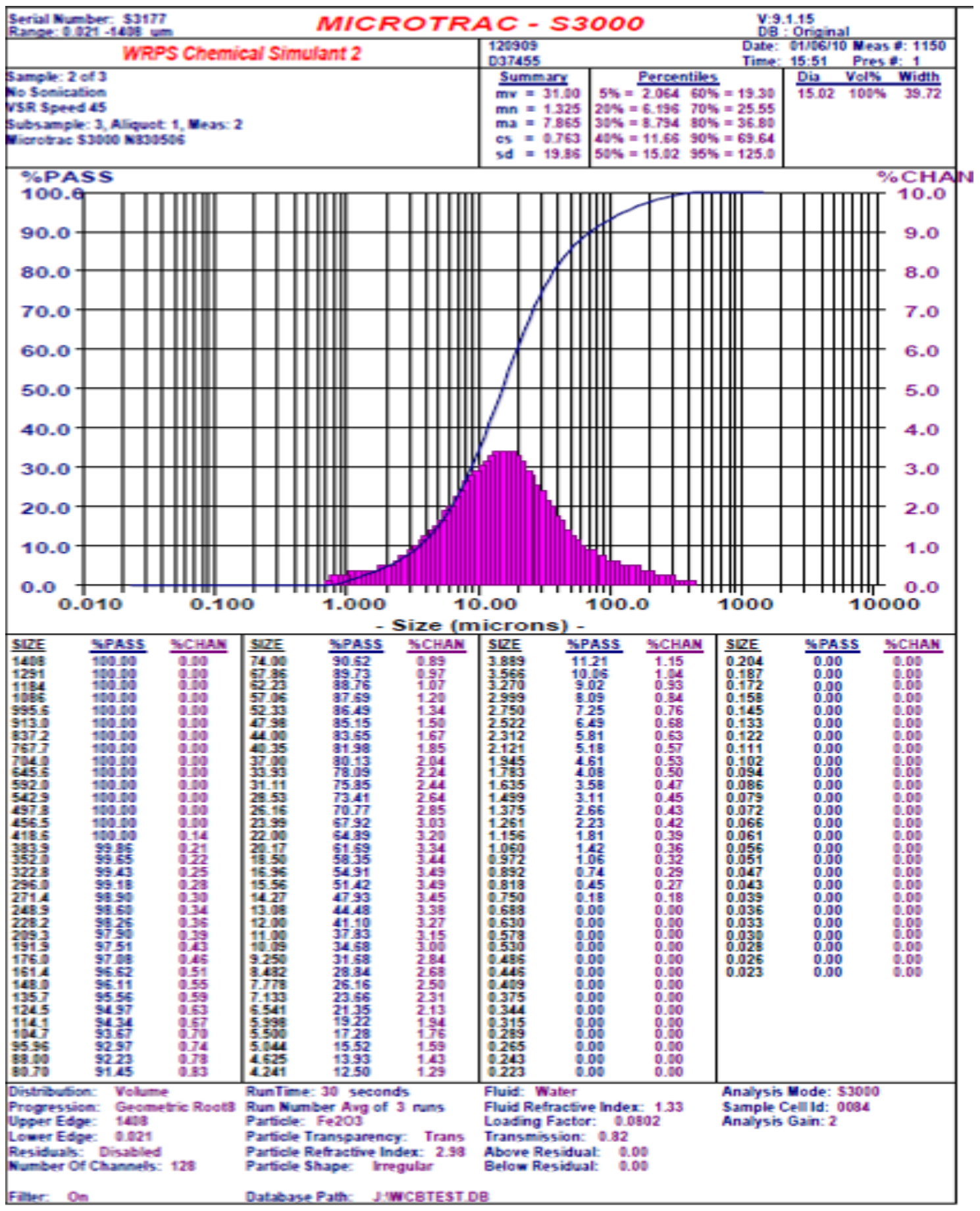

Figure E.2. Simulant 2 PSD.

\section{Reference}

Russell RL, RA Peterson, WC Buchmiller, DE Rinehart, and KJ Cantrell. 2009. Results of Aging Tests of Vendor-Produced Blended Feed Simulant. WTP-RPT-198 Rev. 0, Pacific Northwest National Laboratory, Richland, Washington. 
Appendix F

Simulant Slurry Rheology Flow Curves 



\section{Appendix F: Simulant Slurry Rheology Flow Curves}

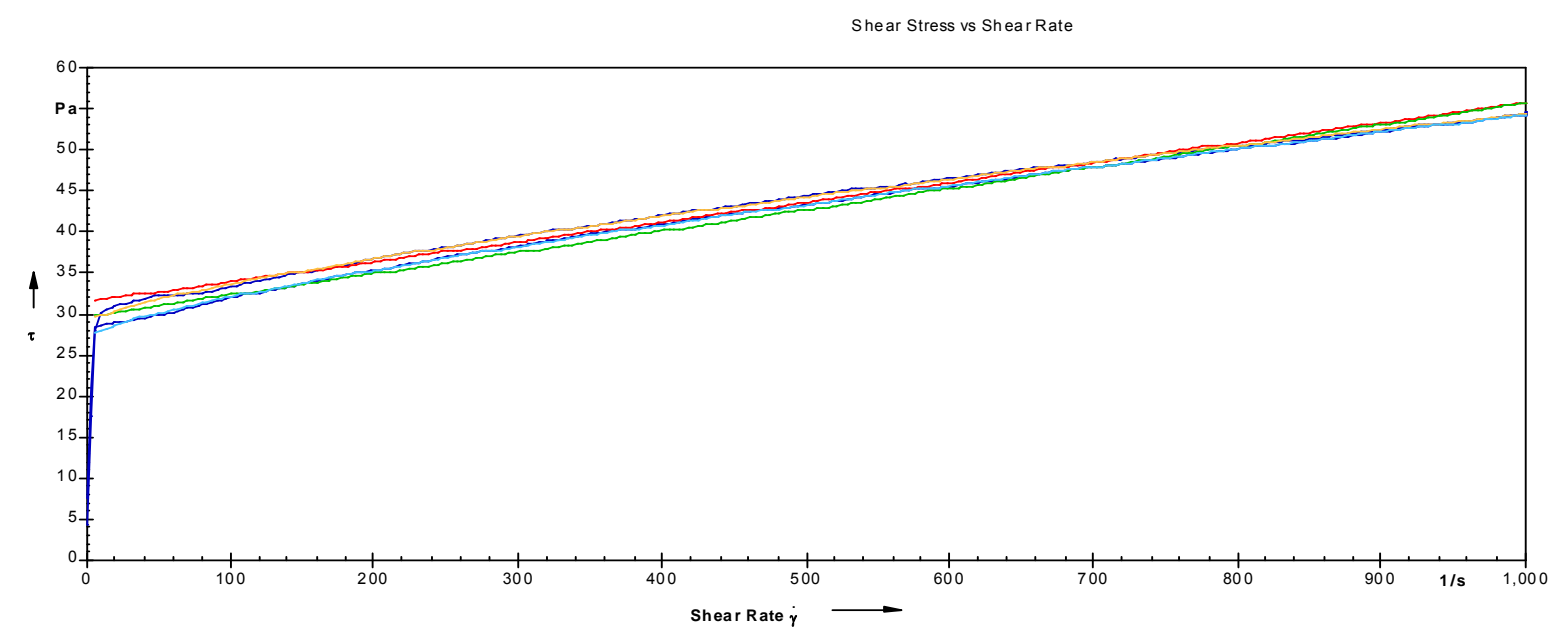

100108_BS1 1

CC27-SN 13634; d =0 mm

$\tau$ Shear Stress

100108_BS1 1 Bingham Up $\operatorname{tau} 0=31.512 \mathrm{~Pa} ;$ eta $\_$inf $=$

- $\tau$ Shear Stress

100108_BS1 1 Bingham Do tau $=29.733 \mathrm{~Pa}$; eta $\_$inf $=$

— $\tau$ Shear Stress

au $0=28.966 \mathrm{~Pa}^{\circ} \mathrm{b}=0.15$

100108 BS1 1 Herschel-Bu

tau $=27.204 \mathrm{~Pa} ; \mathrm{b}=0.15$

Figure F.1. Simulant 1 Slurry, 0.31 Mass Fraction UDS

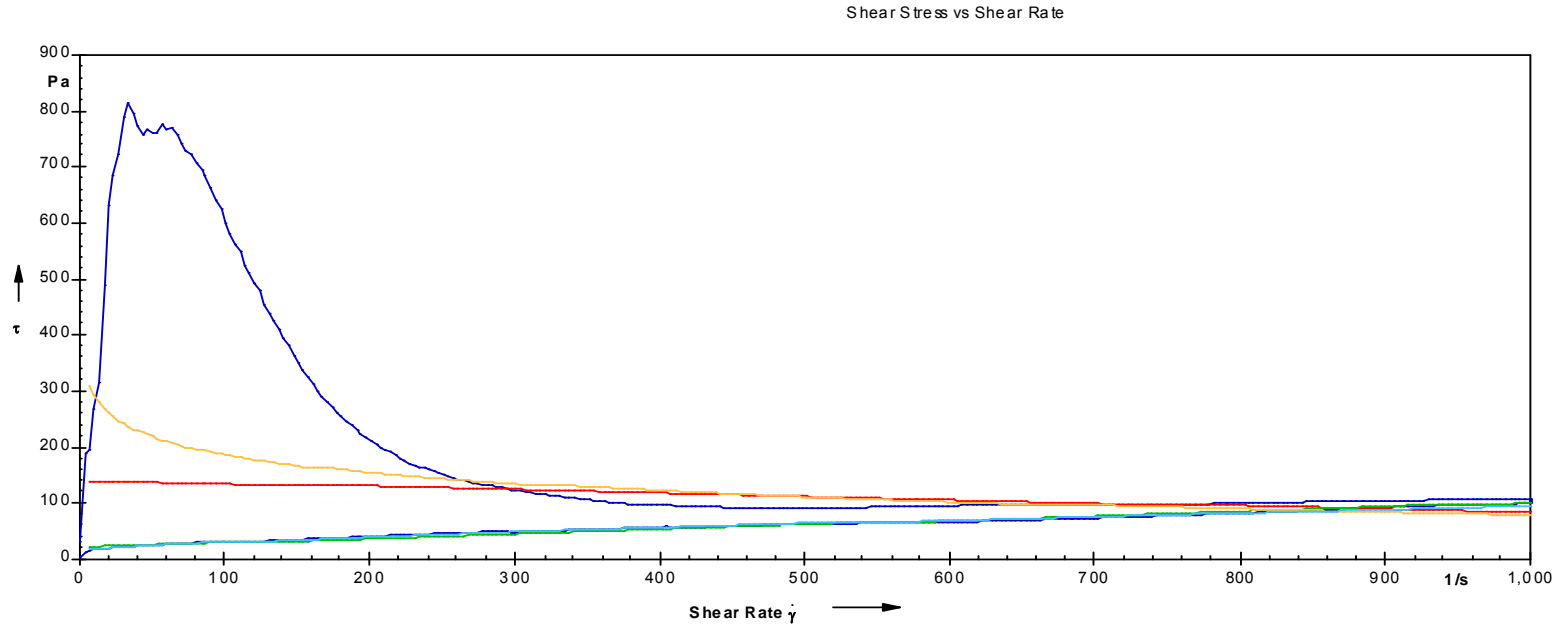

100113_BS\#1 1

CC 27-SN13634; $d=0$ mm

- $\tau$ Shear Stress

100113_BS\#1 1 Bingham

$\operatorname{tau} 0=140.23 \mathrm{~Pa}$; eta

- $\tau$ Shear Stress

100113_BS\#1 1 Bingham

$\operatorname{tau} 0=20.431$ Pa; eta_int

- $\tau$ Shear Stress

00113 BS\#11 1 Hersche

a

$0=13.405$ Pa: b $=0.6$

Figure F.2. Simulant 1 Slurry, Run 1, 0.40 Mass Fraction UDS

Shear $S$ tress vs She ar Rate

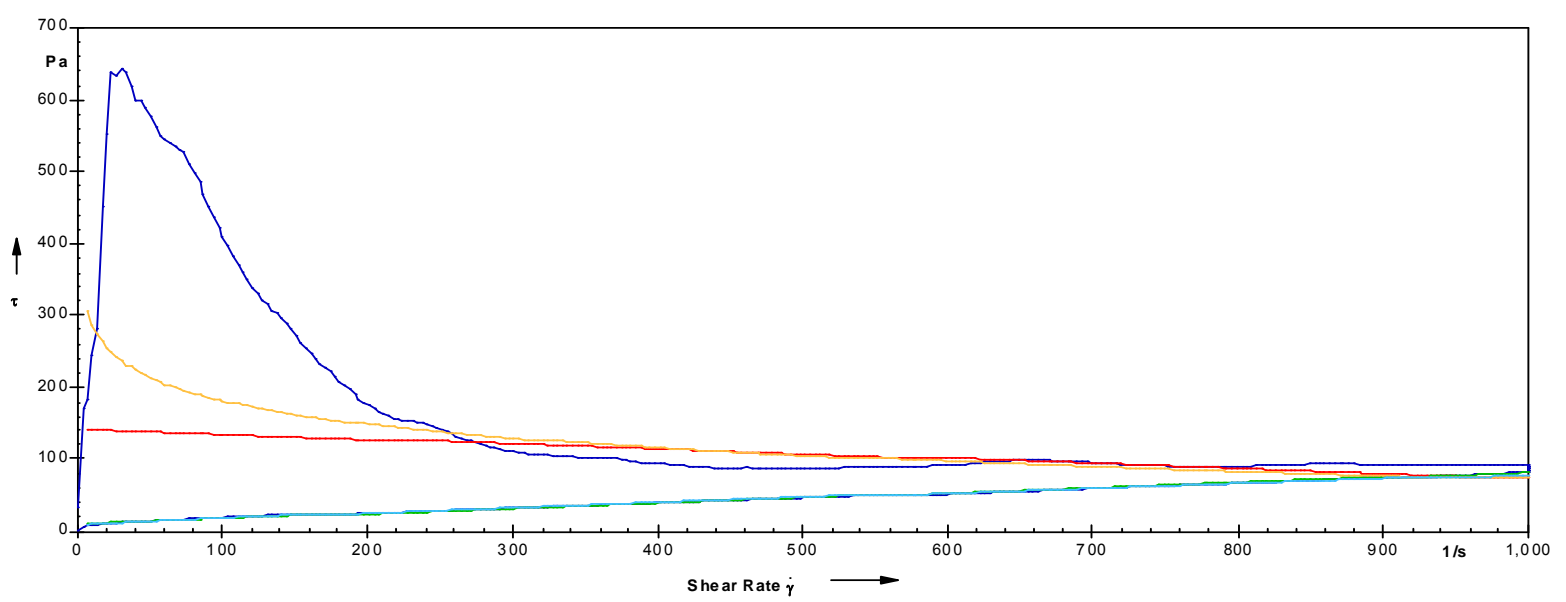

100113_BS\#1 2

CC 27-SN13634; $d=0$ mm

- $\tau$ Shear Stress

100113_BS\#1 2 Bingham

tau $0=141.87$ Pa; eta_inf

- $\tau$ Shear Stress

100113_BS\#1 2 Bingham

$\operatorname{tau} 0=10.845 \mathrm{~Pa} ;$ eta_int

- $\tau$ Shear Stress

00113 BSH1 2 Hersche

$\operatorname{tau} 0=4,839 \mathrm{~Pa} ; \mathrm{b}=-4,4$

100113_BS\#1 2 Hersche

au $0=9.1196 \mathrm{~Pa} ; \mathrm{b}=0.1$

Figure F.3. Simulant 1 Slurry, Run 2, 0.40 Mass Fraction UDS 
Shear Stress vs Shear Rate

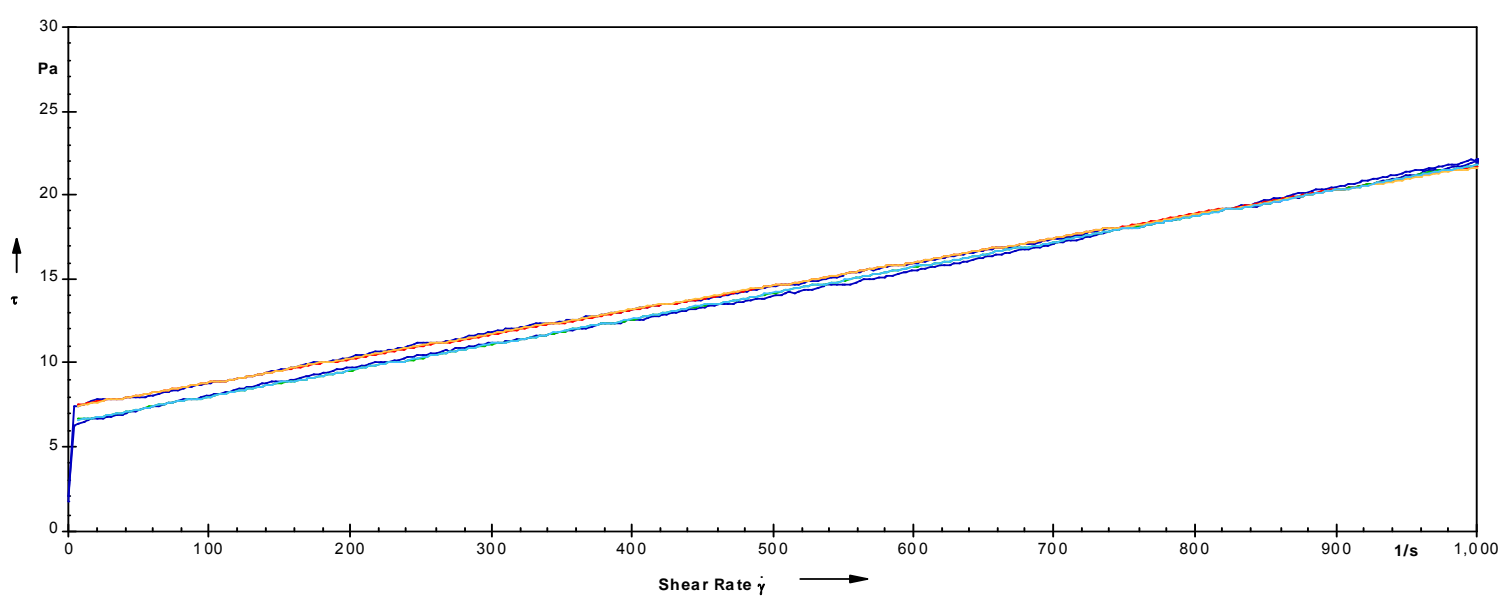

091215_M3-Simulant-2 1 CC 27-SN 13634; $d=0$ m m

- $\tau$ Shear Stress

091215_M3-Simulant-2 1 Bingha $\operatorname{tau} 0=7.4021 \mathrm{~Pa} ;$ eta $\_$inf $=0.0$

- $\tau$ Shear Stres

091215_M3-Simulant-2 1 Bingha

$\operatorname{tau} 0=6.4892 \mathrm{~Pa} ;$ eta_inf $=0.0$

— $\tau$ Shear Stress

091215_M3-Simulant-2 1 Hersc

$\tan 0=7.334 \mathrm{~Pa} \cdot \mathrm{b}=0.016275$

_ Shear Stress

091215 M3 -Simulant-2 1 Hersct $\operatorname{tau} 0=6.4664 \mathrm{~Pa} ; \mathrm{b}=0.015993 ;$

Figure F.4. Simulant 2 Slurry, 0.23 Mass Fraction UDS

Shear Stressus Shear Rate

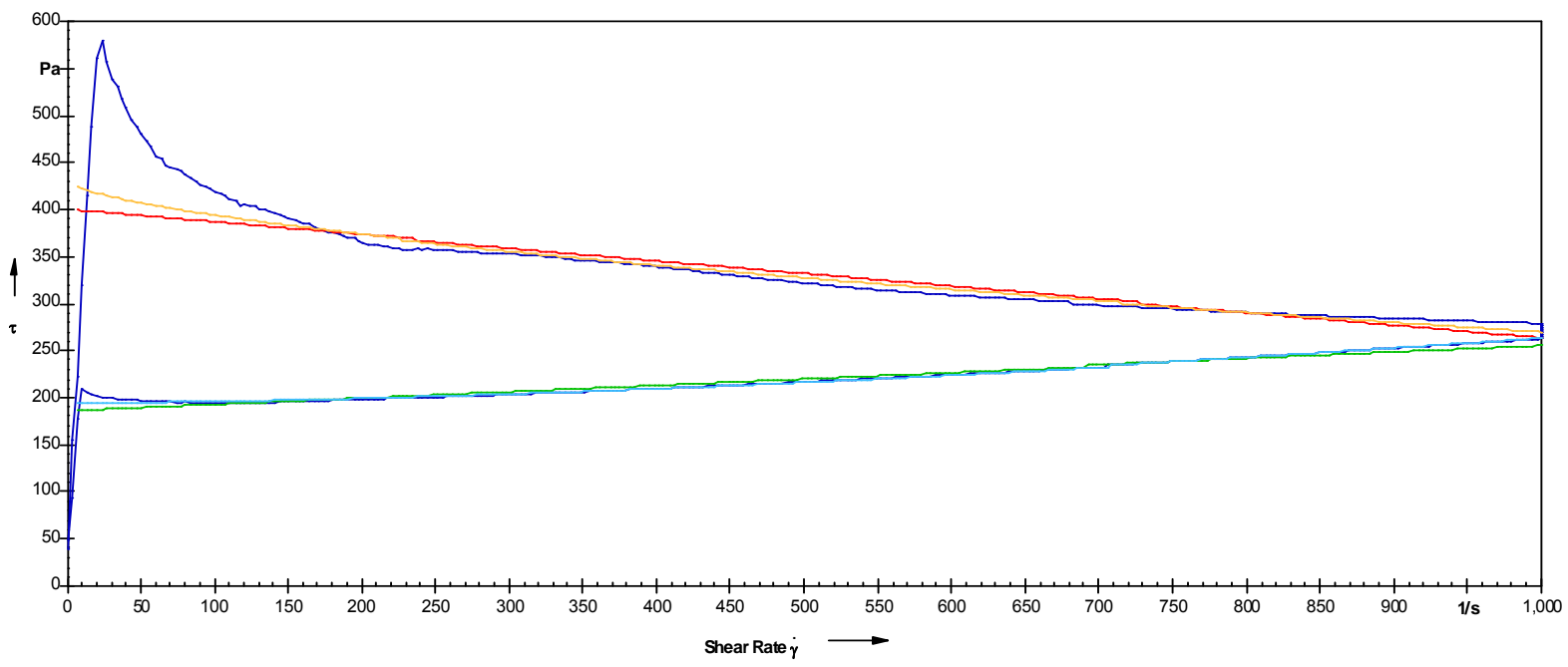

091217_BSH2_Solids 1 CC27-SN13634; $d=0 \mathrm{~mm}$ - $\tau$ Shear Stress 091217_BSH2_Solids $1 \mathrm{Bin}$ tau0 $=400.39$ Pa; eta $\_$inf $:$ - $\tau$ Shear Stress 091217_BSH2_Solids 1 Bin tau0 $=185.83$ Pa; eta_inf $=$ - $\tau$ Shear Stress 091217_BSH2_Solids $1 \mathrm{He}$ tau $=431.75 \mathrm{~Pa} ; \mathrm{b}=-2.0$ - $\tau$ Shear Stress 091217_BSH2_Solids $1 \mathrm{He}$ tau0 $=194.28 \mathrm{~Pa} ; \mathrm{b}=0.00$

Figure F.5. Simulant 2 Slurry, 0.35 Mass Fraction UDS 
PNNL-19250

\section{Distribution}

No. of

Copies

OFFSITE
No. of

Copies

ONSITE

13 Pacific Northwest National Laboratory

G. N. Brown

P7-25

W. C. Buchmiller

K6-24

J. V. Crum

K6-24

P. A. Gauglitz

K7-15

E. C. Golovich

K5-25

L. A. Mahoney

K7-15

D. E. Rinehart

K6-24

R. L. Russell

K6-24

R. D. Scheele

P7-25

B. E. Wells

K7-15

Information Release (pdf)

3 WRPS

N. W. Kirch

R2-58

J. E. Meacham

R2-58

D. J. Washenfelder

R2-58

Distr. 1 




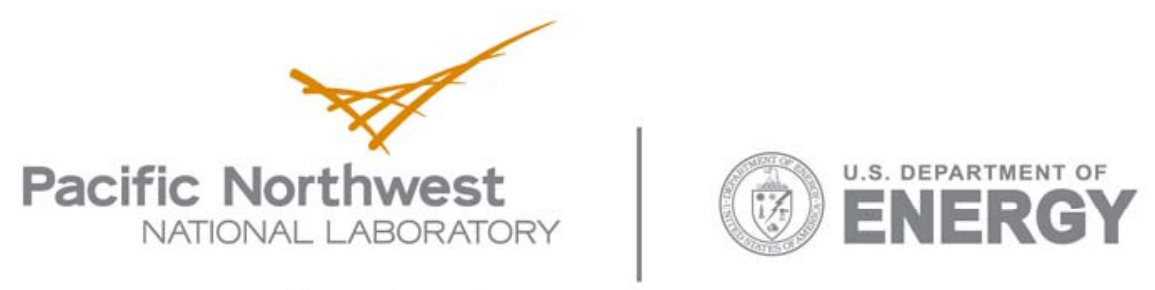

902 Battelle Boulevard

P.O. Box 999

Richland, WA 99352

1-888-375-PNNL (7665)

www.pnl.gov 